\title{
Transuranic (TRU) Waste Phase I Retrieval Plan
}

Prepared for the U.S. Department of Energy Assistant Secretary for Environmental Management

Project Hanford Management Contractor for the

U.S. Department of Energy under Contract DE-AC06-96RL13200

Fluor Hanford

P.O. Box 1000

Richland, Washington 


\section{INFORMATION CLEARANCE FORM}

\begin{tabular}{ll|l}
\hline \multicolumn{1}{|c|}{ A. Information Category } & B. Document Number HNE-4781, Rev. 1 \\
\cline { 2 - 3 }$\square$ Abstract & $\square$ Journal Article & C. Title \\
$\square$ Summary & $\square$ Internet & Transuranic (TRU) Waste Phase I Retrieval Plan \\
$\square$ Visual Aid & $\square$ Software & \\
$\square$ Full Paper & $\square$ Report & \\
$\square$ Other & &
\end{tabular}

E. Required Information

1. Is decument potentially Classified? $\bigotimes$ No $\square$ Yes (MANDATORY)

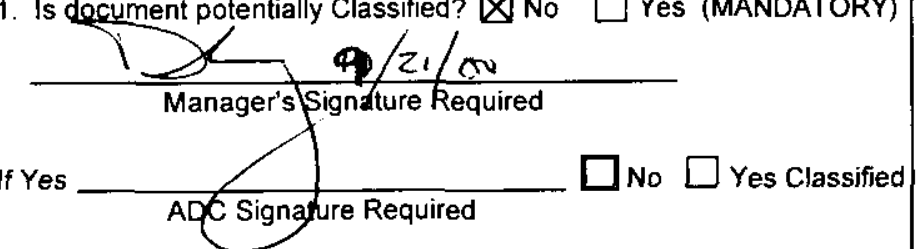

2. Internal Review Required? $\bigotimes$ No $\square$ Yes

If Yes, Document Signatures Below

4. Does Information Contain the Following: (MANDATORY)

a. New or Novel (Patentable) Subject Matter? $\bigotimes_{\text {No }} \square$ Yes

If "Yes", Disclosure No:

b. Information Received in Confidence, Such as Proprietary and/or Inventions?

$\bigotimes$ No $\square$ Yes If "Yes", Affix Appropriate Legends/Notices.

c. Copyrights? $\bigotimes$ No $\square$ Yes If "Yes", Attach Permission.

d. Trademarks? $\square$ No $\bigotimes$ Yes If "Yes", Identify in Document.

Counsel

5. Is Information requiring submission to OSTI? $\quad$ No $\square$ Yes

Program

If Yes UCand $B \& R-$

3. References in the Information are Applied Technology $\bigotimes$ No $\square$ Yes Export Controlled Information

$\bigotimes_{\text {No }} \square$ Yes 7. Charge Code 101689 /ATOO

F. Complete for a Journal Article

1. Title of Journal

G. Complete for a Presentation

1. Title for Conference or Meeting

2. Group Sponsoring

3. Date of Conference

5. Will Information be Published in Proceedings? $\square$ No $\square$ Yes

4. City/State

H. Author/Requestor

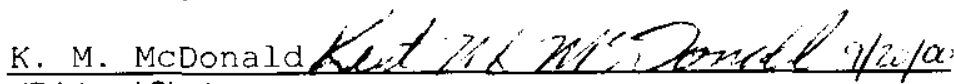
(Print and Sign)

I. Reviewers

Yes Print

6. Will Material be Handed Out? $\square$ No $\square$ Yes

General Counsel

Responsible Manager

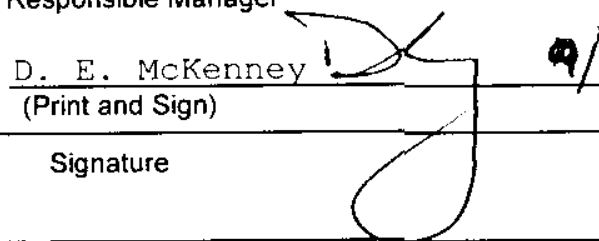

Public Y/N (If N, complete J)

$\square$

Office of External Affairs

DOE-RL

Other 
HNF-4781

Revision 1

\section{Transuranic (TRU) Waste Phase I Retrieval Plan}

Date Published

September 2000

Prepared for the U.S. Department of Energy

Assistant Secretary for Environmental Management

Project Hanford Management Contractor for the

U.S. Department of Energy under Contract DE-AC06-96RL13200

Fluor Hanford

P.O. Box 1000

Richland, Washington

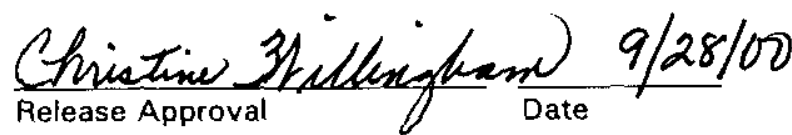




\section{LEGAL DISCLAIMER}

This report was prepared as an account of work sponsored by an agency of the United States Government. Neither the United States Government nor any agency thereof, nor any of their employees, nor any of their contractors, subcontractors or their employees, makes any warranty, express or implied, or assumes any legal liability or responsibility for the accuracy, completeness, or any third party's use or the results of such use of any information, apparatus, product, or process disclosed, or represents that its use would not infringe privately owned rights. Reference herein to any specific commercial product, process, or service by trade name, trademark, manufacturer, or otherwise, does not necessarily constitute or imply its endorsement, recommendation, or favoring by the United States Government or any agency thereof or its contractors or subcontractors. The views and opinions of authors expressed herein do not necessarily state or reflect those of the United States Government or any agency thereof.

This report has been reproduced from the best available copy. 


\section{Transuranic (TRU) Waste Phase I Retrieval Plan}

September 2000

Prepared by

Kent McDonald

Waste Management Federal Services of Hanford, Inc.

Prepared for the U.S. Department of Energy

Approved by:

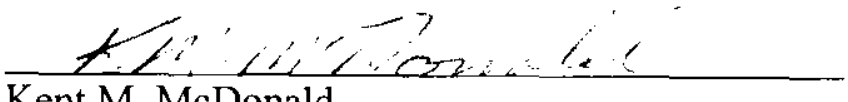

Kent M. McDonald

Systems Engineering/Site Planning and Integration

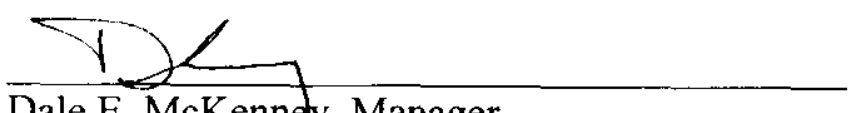

Dale E. McKennoy, Manager

Systems Engizeening/Site Planning and Yhtegration

Roland D. Greenwell, Maneger

Solid Waste Storage and Disposal
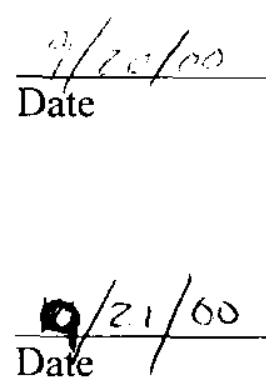

$\frac{9-26-00}{\text { Date }}$ 
HNF-4781

Revision 1

\section{Transuranic (TRU) Waste Phase I Retrieval Plan}

September 2000

Prepared by

Kent McDonald

Waste Management Federal Services of Hanford, Inc.

Prepared for the U.S. Department of Energy

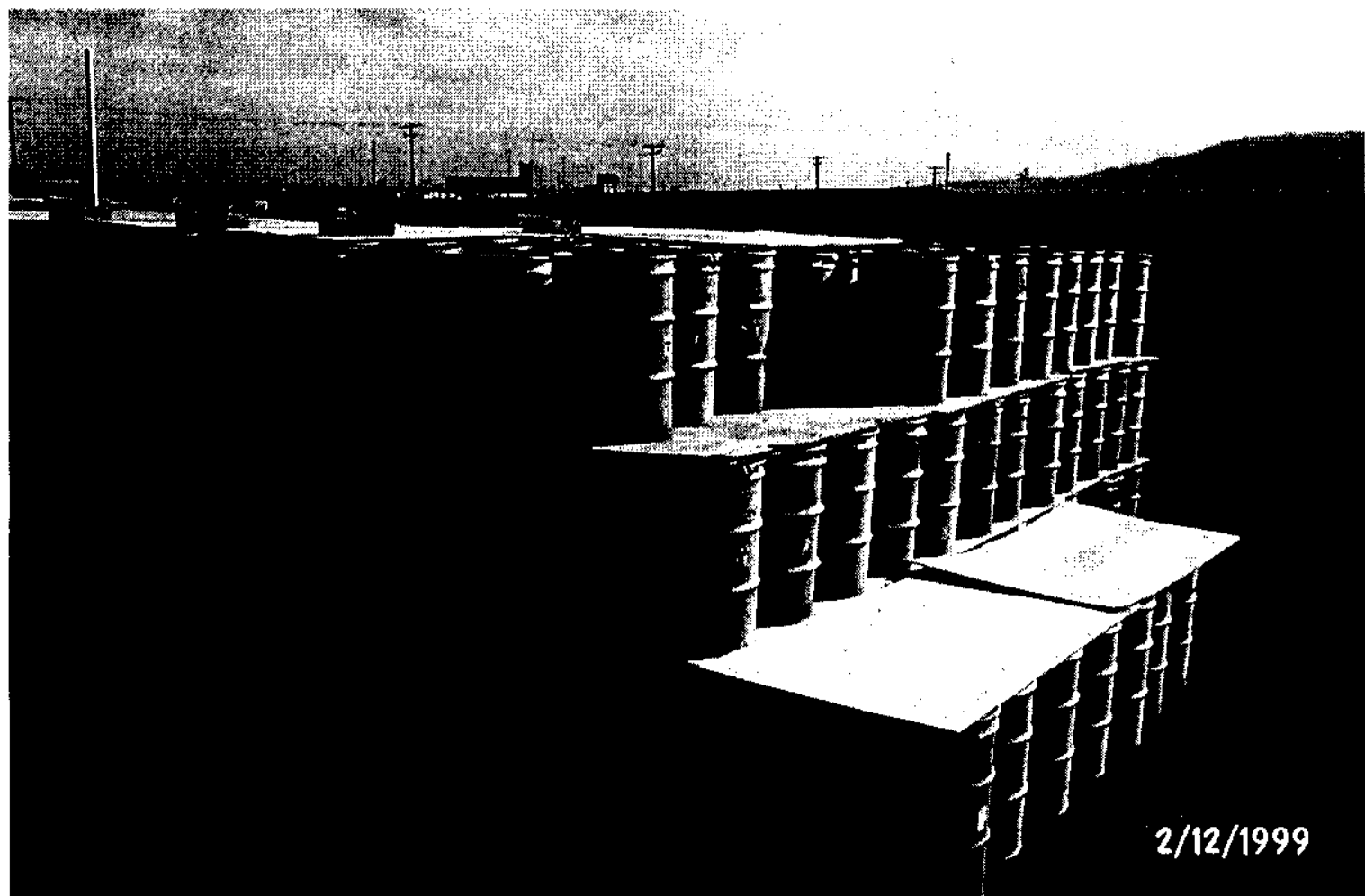




\section{EXECUTIVE SUMMARY}

Since 1970, approximately 37,400 suspect transuranic (TRU) and mixed-TRU (TRUM) waste containers have been placed in retrievable storage at the Hanford Site. The majority of these waste containers (approximately 26,200) are stacked vertically on asphalt pads in earth-covered trenches in the Solid Waste Burial Grounds (SWBG). Smaller amounts of TRU waste are in aboveground storage in the Central Waste Complex (CWC), a Resource Conservation and Recovery Act (RCRA) permitted storage unit. Current plans call for retrieval of the TRU and TRUM wastes from the SWBG. The retrieved waste containers will then be moved to interim storage at the CWC, where they will be staged prior to being accepted for processing at the Waste Receiving and Packaging (WRAP) Facility. WRAP will prepare the waste for shipment to the Waste Isolation Pilot Plant (WIPP) for disposal.

The Hanford Federal Facility Agreement and Consent Order, also referred to as the Tri-Party Agreement or TPA (Ecology et al., 1989), has several milestones associated with the retrieval of post-1970 TRU wastes. Tri-Party Agreement (TPA) milestone M-91-04 requires that the DOE "complete construction of small container contact handled (CH) TRU/TRUM retrieval facility(s) and initiate (Project W-113) retrieval of small container TRU/TRUM from 200 Area burial grounds" by September 30, 2000. Additionally, M-91-07 requires that the DOE "complete Project $W-113$ for post-1970 CH TRU/TRUM retrieval" by September 30, 2004. The retrieval activities encompassed by these two milestones are commonly referred to as Phase I retrieval.

When the TPA milestones were negotiated, Phase I retrieval was to have been accomplished by Project W-113. Project W-113 would have retrieved approximately 10,000 55-gallon drums (the "small containers" referred to in the TPA) of $\mathrm{CH}$ suspect TRU waste in Burial Ground 218-W$4 \mathrm{C}$, Trench 4. Project W-113 also included the construction of a structure over the trench, use of assay and non-destructive examination (NDE) equipment near the trench, support buildings, etc. Project $\mathrm{W}-113$, as originally proposed, is unfunded.

The approach used for the initial planning of Project W-113 was similar to the approach that was pursued at both Savannah River Site (SRS) and Los Alamos National Laboratory (LANL). Since 1997, however, both sites have demonstrated that retrieval, transportation, venting, and subsequent storage of unvented TRU 55-gallon drums can be conducted safely through open-air retrieval. Open-air retrieval has been proven to be safe, cost-effective, and in many ways, preferred over enclosed retrieval. This plan provides a new strategy for the Phase I retrieval that meets the intent of TPA milestone M-91 and Project W-113, and incorporates the lessons learned during TRU retrieval campaigns at Hanford, LANL, and SRS.

This Phase I retrieval plan describes the activities associated with the assessment of approximately 10,000 suspect TRU drums located in burial ground $218-\mathrm{W}-4 \mathrm{C}$ and the retrieval of those drums verified to contain TRU waste. Seven asphalt pad trenches in $218-\mathrm{W}-4 \mathrm{C}$ contain suspect-TRU waste; four of these (Trenches 1, 4, 20, and 29) contain large numbers of suspectTRU drums. Trenches 1, 20, and 29 contain waste that has not been covered with soil, which allows about 1500 drums to be retrieved without excavation. The other three trenches in $218-\mathrm{W}$ $4 \mathrm{C}$ (Trenches 7, 19, and 24) are not candidates for Phase I retrieval because they contain significant numbers of boxes.

The 55-gallon suspect-TRU drums will be retrieved from the four candidate trenches, checked for structural integrity, overpacked if necessary, and assayed to determine if the drum is LLW $(<100$ $\mathrm{nCi} / \mathrm{g}$ ) and can remain disposed of in the SWBG. TRU waste will be retrieved from the burial ground and stored at the CWC until it can be shipped to WRAP for processing. 


\section{TABLE OF CONTENTS}

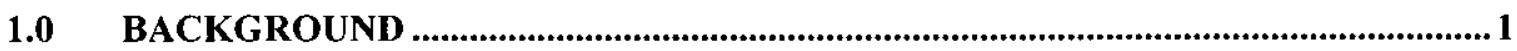

2.0 INTRODUCTION............................................................................................................

3.0 RETRIEVAL EXPERIENCE......................................................................................

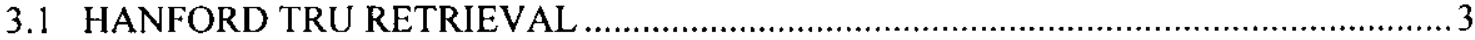

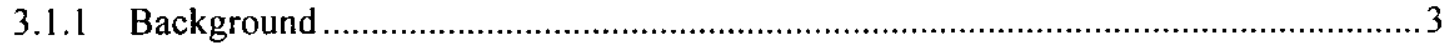

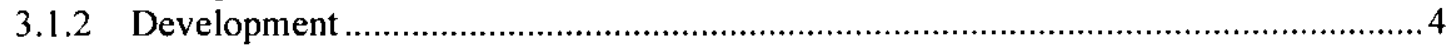

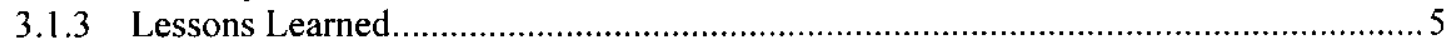

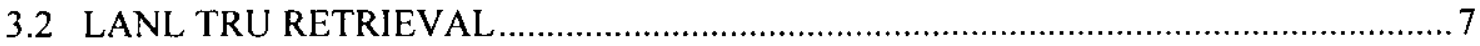

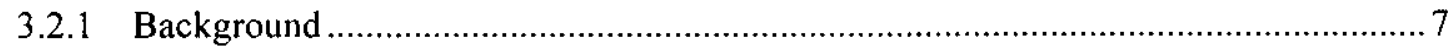

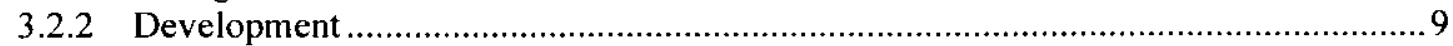

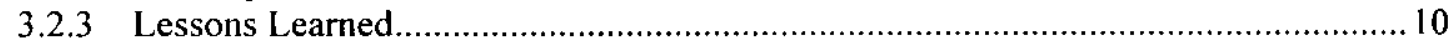

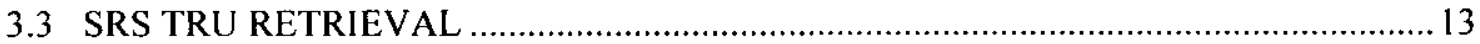

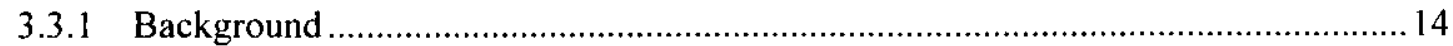

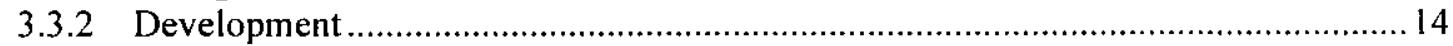

3.3.3 Lessons Learned.......................................................................................... 17

4.0 OPERATIONAL APPROACH .........................................................................20

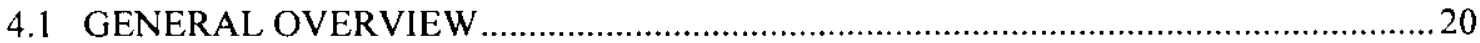

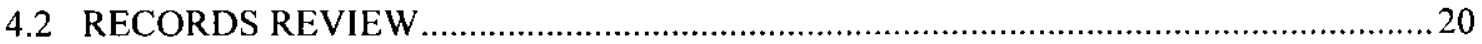

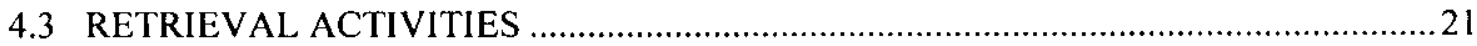

4.3.1 Pre-Start Steps

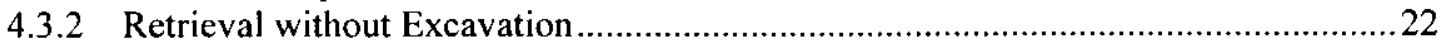

4.3.3 Retrieval with Excavation...............................................................................25

4.3.4 Retrieval Volumes/Annual Campaigns...............................................................26

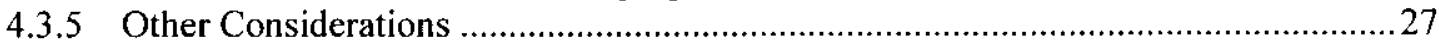

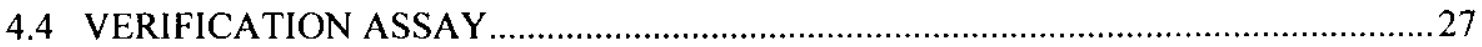

4.5 CONTAINER VENTING AND HEADSPACE GAS SAMPLING ………………......28

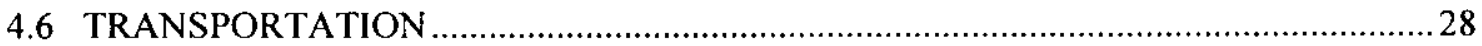

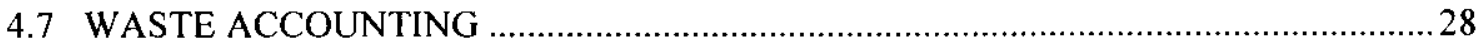

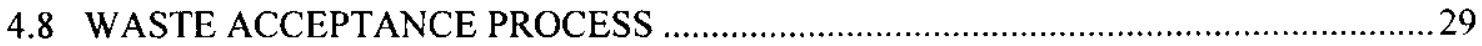

5.0 ALTERNATIVES CONSIDERED ……………….......................................................31

5.1 DRUM AGE

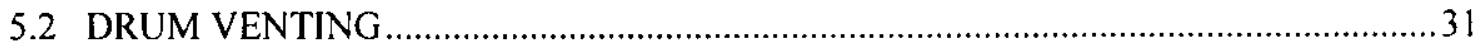

5.3 RETRIEVAL UNDER A CONTAINMENT STRUCTURE …………..........................31

6.0 DOCUMENTATION ...............................................................................................33

6.1 NATIONAL ENVIRONMENTAL POLICY ACT (NEPA) ………………………........33

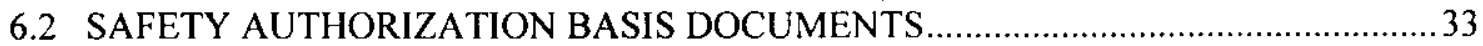

6.2.1 Solid Waste Burial Grounds Safety Basis.................................................................34

6.2.2 Safety Analysis Report for Packaging in Steel Drums ..............................................34

6.2.3 Central Waste Complex Interim Safety Basis..........................................................35

6.2.4 Waste Receiving And Packaging Facility Final Safety Analysis Report....................35

6.2.5 T Plant Interim Safety Basis ................................................................................36

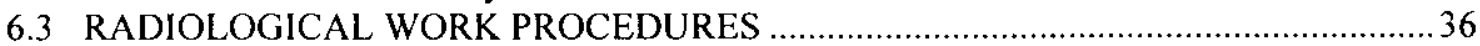

6.4 CRITICALITY PREVENTION SPECIFICATION ………………….......................... 


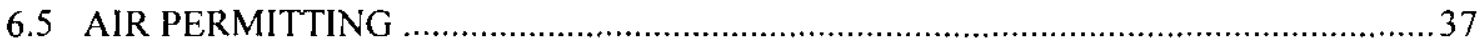

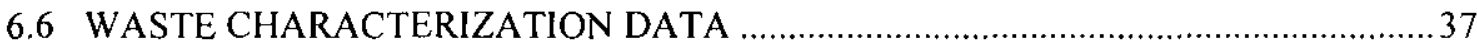

6.6.1 Historical Records for Post-1970 Suspect-TRU Waste............................................. 38

6.6.2 Documentation of Data Collected During Phase I Retrieval ................................... 39

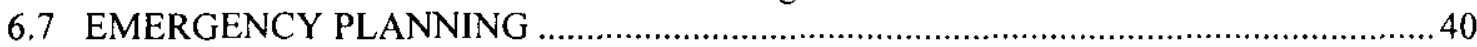

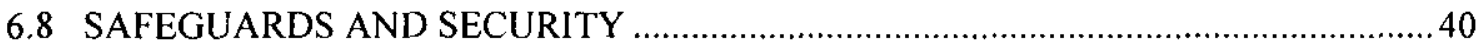

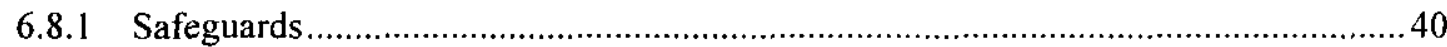

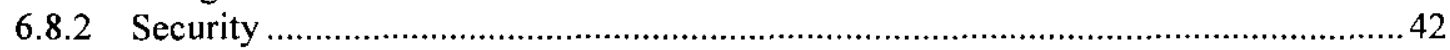

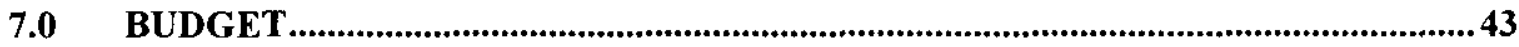

8.0 SCHEDULE

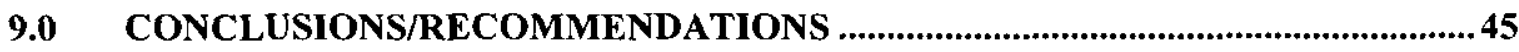

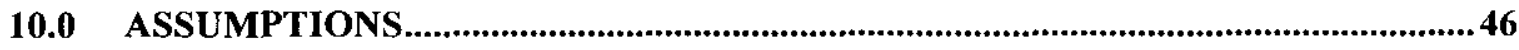

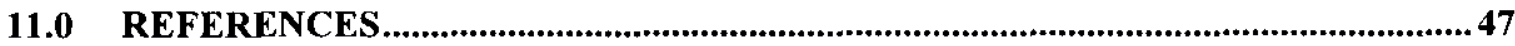

\section{LIST OF APPENDICES}

APPENDIX A Sample Statement of Work and Specification for Mobile Assay System ..........A-1

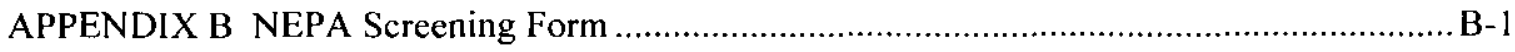

APPENDIX C Draft Strategy for Preparation of Notice of Construction for Operation of Container Venting System

APPENDIX D Cost Estimating Worksheet for Phase I Retrieval ........................................ D-1

APPENDIX E Schedule for Phase I Retrieval ................................................................... E-1 
HNF-4781, Revision 1

\section{LIST OF FIGURES}

Figure 4-1. TRU Retrieval Flow Diagram - No Excavation............................23

\section{LIST OF TABLES}

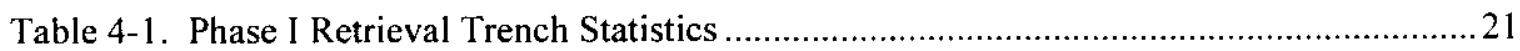

Table 4-2. Phase I Annual Retrieval of Suspect-TRU Drums. .................................................26

Table 7-1. Estimated Funding Requirements for Phase I TRU Retrieval..................................43 


\section{Acronyms and Abbreviations}

\begin{tabular}{|c|c|}
\hline AEC & U. S. Atomic Energy Commission \\
\hline $\mathrm{AK}$ & acceptable knowledge \\
\hline $\mathrm{CH}$ & contact handled \\
\hline $\mathrm{Ci}$ & curie \\
\hline CPS & Criticality Prevention Specification \\
\hline CVS & Container Venting System \\
\hline CWC & Central Waste Complex \\
\hline $\mathrm{DE}-\mathrm{Ci}$ & dose equivalent curies \\
\hline DNFSB & Defense Nuclear Facilities Safety Board \\
\hline DOE & U. S. Department of Energy \\
\hline DVS & drum venting system \\
\hline EAL & emergency action level \\
\hline Ecology & Washington State Department of Ecology \\
\hline EPA & U. S. Environmental Protection Agency \\
\hline FGE & fissile gram equivalent \\
\hline FONSI & finding of no significant impact \\
\hline FRP & fiberglass-reinforced plywood \\
\hline FSAR & Final Safety Analysis Report \\
\hline FY & fiscal year \\
\hline GPR & ground penetrating radar \\
\hline HDW-EIS & Hanford Defense Waste Environmental Impact Statement [see DOE 1987] \\
\hline HEPA & high efficiency particulate air [filter] \\
\hline HPT & Health Physics Technician \\
\hline HWOP & Hazardous Waste Operating Permit \\
\hline INEEL & Idaho National Engineering and Environmental Laboratory \\
\hline ISB & Interim Safety Basis \\
\hline ISPR & Independent Scientific Peer Review \\
\hline LANL & Los Alamos National Laboratory \\
\hline LEL & lower explosive limit \\
\hline LLW & low-level waste \\
\hline $\mathrm{nCi}$ & nanocurie \\
\hline NDE & non-destructive examination \\
\hline NEPA & National Environmental Policy Act of 1969 \\
\hline NFT & Nuclear Filter Technology, Inc. \\
\hline NMED & New Mexico Environmental Department \\
\hline NOC & notice of construction \\
\hline ORR & Operational Readiness Review \\
\hline PIN & Package Identification Number \\
\hline PPE & personnel protective equipment \\
\hline RCRA & Resource Conservation and Recovery Act of 1976 \\
\hline RH & remote-handled \\
\hline ROD & Record of Decision \\
\hline RTR & real time radiography \\
\hline RWP & radiological work permit \\
\hline RUBB & RUBB Building Systems, Inc. \\
\hline SAR & safety analysis report \\
\hline SARP & safety analysis report for packaging \\
\hline SRS & Savannah River Site \\
\hline SWITS & Solid Waste Information and Tracking System [database] \\
\hline
\end{tabular}


HNF-4781, Revision 1

TPA

TRU

TRUM

TSD

TWISP

USQ

USQD

WAP

WIPP

WRAP

Tri-Party Agreement (Hanford Federal Facility Agreement and Consent Order) transuranic

mixed-TRU [waste]

Treatment, Storage, and/or Disposal

Transuranic Waste Inspectable Storage Project (LANL)

unreviewed safety question

unreviewed safety question determination

Waste Acceptance Plan

Waste Isolation Pilot Plant

Waste Receiving and Packaging Facility 


\subsection{BACKGROUND}

Since 1970, approximately 37,400 of suspect transuranic (TRU) and mixed-TRU (TRUM) waste containers have been placed in 20-year retrievable storage. Most of this waste is buried in trenches of several different designs in the Solid Waste Burial Grounds (SWBG). Smaller amounts of TRU waste are in aboveground interim storage in the Central Waste Complex (CWC).

In the January 23, 1998 Federal Register, the U.S. Department of Energy (DOE) issued a Record of Decision (ROD) which announced its decision that final disposal of TRU waste is to occur at the Waste Isolation Pilot Plant (WIPP). This decision was based on the evaluation in the Department of Energy Waste Management Programmatic Environmental Impact Statement (DOE 1997). The Hanford Site Solid Waste Environmental Impact Statement, which is currently in preparation, will evaluate this and other disposal alternatives. For Hanford's post-1970 TRU waste to be disposed of at WIPP, the TRU and TRUM waste in the SWBG will need to be retrieved, characterized, and processed, as necessary, in the Waste Receiving and Processing (WRAP) facility to meet WIPP waste acceptance criteria.

The Hanford Federal Facility Agreement and Consent Order, also referred to as the Tri-Party Agreement or TPA (Ecology et al., 1989), has several milestones associated with the retrieval of post-1970 TRU wastes. Tri-Party Agreement (TPA) milestone M-91-04 requires that the DOE "complete construction of small container contact handled (CH) TRU/TRUM retrieval facility(s) and initiate (Project W-113) retrieval of small container TRU/TRUM from 200 Area burial grounds" by September 30, 2000. Additionally, M-91-07 requires that the DOE "complete Project W-113 for post-1970 CH TRU/TRUM retrieval" by September 30, 2004. The retrieval activities encompassed by these two milestones are commonly referred to as Phase I retrieval.

When the TPA milestones were negotiated, Phase I retrieval was to have been accomplished by Project W-113. Project W-113 would have retrieved approximately 10,000 55-gallon drums (the "small containers" referred to in the TPA) of CH suspect TRU waste in Burial Ground 218-W$4 C$, Trench 4. Project W-113 also included the construction of a structure over the trench, use of assay and non-destructive examination (NDE) equipment near the trench, support buildings, etc. Project W-113, as originally proposed, is unfunded.

The approach used for the initial planning of Project W-113 was similar to the approach that was pursued at both Savannah River Site (SRS) and Los Alamos National Laboratory (LANL). Since 1997, however, both sites have demonstrated that retrieval, transportation, venting, and subsequent storage of unvented TRU 55-gallon drums can be conducted safely through open-air retrieval. Open-air retrieval has been proven to be safe, cost-effective, and in many ways, preferred over enclosed retrieval. 


\subsection{INTRODUCTION}

From 1970 to 1987 , TRU and suspect TRU wastes at Hanford were placed in the SWBG. At the time of placement in the SWBG these wastes were not regulated under existing Resource Conservation and Recovery Act (RCRA) regulations, since they were generated and disposed of prior to the effective date of RCRA at the Hanford Site (1987). From the standpoint of DOE Order $5820.2 \mathrm{~A}^{\prime}$, the TRU wastes are considered retrievably stored, and current plans are to retrieve these wastes for shipment to WIPP for disposal.

This plan provides a strategy for the Phase I retrieval that meets the intent of TPA milestone M91 and Project $\mathrm{W}-113$, and incorporates the lessons learned during TRU retrieval campaigns at Hanford, LANL, and SRS. As in the original Project W-113 plans, the current plan calls for examination of approximately 10,000 suspect-TRU drums located in the $218-\mathrm{W}-4 \mathrm{C}$ burial ground followed by the retrieval of those drums verified to contain TRU waste. Unlike the older plan, however, this plan proposes an open-air retrieval scenario similar to those used for TRU drum retrieval at LANL and SRS.

Phase I retrieval consists of the activities associated with the assessment of approximately 10,000 55 -gallon drums of suspect TRU-waste in burial ground $218-\mathrm{W}-4 \mathrm{C}$ and the retrieval of those drums verified to contain TRU waste. Four of the trenches in 218-W-4C (Trenches 1, 4, 20, and 29) are prime candidates for Phase I retrieval because they contain large numbers of suspect TRU drums, stacked from 2 to 5 drums high, on an asphalt pad. In fact, three of the trenches (Trenches 1,20 , and 29) contain waste that has not been covered with soil, and about 1500 drums can be retrieved without excavation. The other three trenches in $218-\mathrm{W}-4 \mathrm{C}$ (Trenches 7,19 , and 24) are not candidates for Phase I retrieval because they contain significant numbers of boxes.

Drums will be retrieved from the four candidate trenches, checked for structural integrity, overpacked, if necessary, and assayed at the burial ground. A mobile assay system will be used to determine if the drum is LLW (i.e., contains $<100 \mathrm{nCi} / \mathrm{g}$ ). LLW will remain disposed of in the $218-\mathrm{W}-4 \mathrm{C}$ Burial Ground. TRU waste will be retrieved and staged in the burial ground until it can be shipped to the CWC. The TRU drums will be stored at the CWC until they can be moved to WRAP. The WRAP facility will prepare the waste for shipment to WIPP for final disposal. For planning purposes, approximately $50 \%$ of the 10,000 drums have been estimated to contain LLW.

${ }^{1}$ DOE Order 435.1, Radioactive Waste Management, was issued by DOE 7/9/99. The applicability of this Order will be determined in an Implementation Plan to be developed in FY 2000. 


\subsection{RETRIEVAL EXPERIENCE}

Inspections of contact-handled TRU drums were conducted at the four major DOE TRU drum storage sites: INEEL, SRS, LANL, and Hanford during the 1970s, 1980s, and 1990s. These inspections were designed to gather information on container storage life in the various underground storage environments to determine if the stored containers could comply with the 20-year Nuclear Regulatory Commission mandated retrievable storage limit. When the 20-year retrievable storage limit was imposed in 1970, it was envisioned that the waste would be retrieved and placed within a national geologic repository within 20 years.

Planning for large-scale retrieval of the contact-handled TRU wastes stored at DOE sites began in the late $1980 \mathrm{~s}$ in an effort to comply with newly mandated state and federal regulations. In all cases, very costly projects coupled with equally expensive processing buildings were originally envisioned to accomplish the necessary TRU retrieval activities. Over the last five years (19941999), contact-handled TRU waste retrieval has been conducted at Hanford, LANL, and SRS. Each of these three sites had different drivers to begin retrieval. The following sections provide the background and lessons learned from these retrieval activities.

\subsection{HANFORD TRU RETRIEVAL}

\subsubsection{Background}

The plan for the Hanford 1994 TRU Drum Retrieval Project, a pilot designed to study the retrieval process and gain information necessary for full-scale retrieval (then identified as Project W-113), was begun in 1988. The original planning document (Anderson, 1989) defined the scope and developed a plan to provide the information and methodology required to work-off retrievably stored Hanford wastes. The document divided the program into three parts:

- Part I, an existing records study;

- Part II, a TRU drum retrieval and container inspection project that would include nondestructive examination (NDE) and nondestructive assay; and

- Part III, a glovebox examination of the retrieved wastes to determine and characterize container contents.

The Part I document (Anderson, 1991), which was originally completed in May 1988, evaluated historical data from Hanford waste records. This document was controversial due to the estimated volume of Hanford remote-handled transuranic (RH-TRU) waste, which was increased to 5,000 cubic feet ( 600 percent higher than previous estimates). This new total equaled the national DOE total for RH-TRU waste. Previous documents had not recognized the volume of RH-TRU waste in trenches and presented only the volumes for RH-TRU contained in caissons.

The Part II document (Anderson and Duncan, 1989) described nineteen "sampling sites" selected to examine unique waste storage configurations and retrieve waste containers from among the entire inventory of Hanford stored TRU waste containers $(37,400)$. The selection of sampling sites was based on the waste storage configuration, while the sample size was derived statistically. The program was designed to collect the waste characterization data necessary to plan full-scale TRU retrieval at Hanford as well as to provide information necessary to support WRAP facility design. 
Part II was divided into two projects, which were governed by two separate safety analysis reports (SARs). One SAR (Joyce and Harker, 1993) was developed for the inspection and retrieval of vented drums (first five sites), while a proposed second SAR was to cover unvented container inspection and retrieval at the remaining fourteen sites. This division was made because of the postulated increased potential of hydrogen in the unvented drums (although no technical data had been gathered at the time to support this) and the possibility of drum explosions, resultant fire, and radionuclide release.

An additional Part Il task was the development, fabrication, and testing of a container venting system to vent unvented containers (i.e., those without a Hanford vent clip) that were placed in 20-year retrievable storage before 1978. The Container Venting System (CVS) was developed at Hanford to fulfill this purpose.

Hanford was the only DOE Site to vent drums (using the Hanford-developed vent clip) prior to the advent of the WIPP Nucfil ${ }^{12}$ filter. The Hanford vent clip is a one-inch wide strip of metal (26 gage stainless steel) bent to fit over the drum so the lid gasket would be compressed and not make a complete seal to the drum when tightened in place. The gap in the lid gasket allowed generated gases to escape the drum while retaining particulate radionuclides. The vent clip was designed to vent the maximum gas volume evolved during testing, and the vent rate exceeded the maximum gas generation rate by 900 percent (Ludowise, 1978). No contamination release was ever recorded as a result of the vent clip. The vent clips were installed on all TRU waste drums generated at Hanford by 1979. Shipments of offsite drums equipped with vent clips were first documented as being received in 1980 (Duncan, 1995).

In an initial Part III document (Demiter, 1988), facilities were identified for waste container opening, waste sorting, and waste characterization. The Part III program was discontinued in 1991 with the expectation that the WRAP facility would conduct all waste container opening, sorting, and characterization required to meet WIPP waste acceptance criteria.

\subsubsection{Development}

Plans for the Pilot TRU Drum Retrieval Project were driven largely by safety concerns. The SAR, which placed many restrictions on the project that affected work methods and development, became the over-riding element of the vented TRU Drum Retrieval Project. Procedures, Hazardous Waste Operating Permit (HWOP), soil sampling plan, training plan, and many other draft documents were prepared, based on the SAR requirements. Ultimately, drums were retrieved from the first two sites only. The most recent drums from these sites were placed in the burial grounds between 1980 and 1982 .

Training activities for the Pilot TRU Drum Retrieval Project included emergency response, onthe-job training, and procedures. Mock-up training was also included. A mock-up of a drum module was constructed and retrieval training was to be conducted step by step. However, in an effort to complete the mock-up training, steps were left out or done out of order. A critique of the mock-up training was never conducted and, as a result, the mock-up training was of minimal value.

Other parallel activities of the program continued, unaffected by the development of the SAR. These included the following activities:

\footnotetext{
${ }^{2}$ Nucfil is a registered trademark of Nuclear Filter Technology, Inc.
} 
- Hanford soils corrosion assessment, which was initiated by placing metal coupons in Hanford soils for evaluation in later years.

- Development of container venting capabilities, which consisted of the fabrication and testing of the CVS.

- Ultrasonic equipment development, which included deploying an NDE system in the field to inspect drum wall thickness and probe modules with a borescope at the retrieval sites.

- In situ inspection techniques of ground penetrating radar (GPR) to map the TRU burial ground trenches.

- Sharing of technologies, developments, and issues with other DOE sites.

Factory acceptance testing for the CVS was completed in April 1992, and the CVS was shipped to Hanford and tested to the Operational Testing Procedure. A Hanford site stop work delayed the start of CVS testing approximately nine months; however, operational testing of the CVS was finally completed in June 1993. The work delay did allow for completion of the CVS explosivity testing by the U.S. Bureau of Mines. A subsequent document "Explosion Testing of the Container Venting System" (Demiter, 1993) supported the CVS design and drilling concept to vent drums.

The Bureau of Mines work used an advanced infrared camera to quantify temperatures reached while drilling metal drum lid coupons and $1 / 4$-inch thick steel plate coupons (to simulate drilling boxes). The temperatures achieved during the testing were $365 \mathrm{C}$ below the ignition point of a stoichiometric hydrogen-air gas mixture and $835 \mathrm{C}$ below the ignition point of a methane-air stoichiometric gas mixture.

Redirection of Phase II program activities to vented drum retrieval caused a cessation of all CVS work at the end of fiscal year (FY) 1994. The CVS and all support equipment were shipped to storage in FY 1995.

Retrieval of uncovered drums in FY 2000 resulted in discovery of a larger number of unvented drums than was expected at that time. The unvented drums (about 76) came from two shipments of TRU waste from Sequoyah Fuels that were generated prior to 1985 under a version of acceptance criteria that did not require venting devices, but were shipped to the Low-Level Burial Grounds and placed in 1985 . None of the drums were visually observed to be pressurized.

\subsubsection{Lessons Learned}

The original scope of the Hanford Pilot TRU Drum Retrieval Project was to provide the information and methodology required for full-scale retrieval. Although TRU drum retrieval was conducted at only two retrieval sites, several findings concerning the condition of the drums stored in 20-year retrievable storage were made. The drums that were inspected and retrieved had been on an asphalt pad and covered with a tarp and soil for approximately 14 years. Some of the lessons learned from the pilot retrieval that are applicable to the current retrieval efforts are: 
1. Corrosion of the 55-gallon drums is expected to be negligible, and the suspect-TRU drums are estimated to have a life of 40 years in their present storage configuration. Drum corrosion data gathered during pilot retrieval directly correlated with earlier data gathered during a 1982 drum inspection (inspected after 8.5 years in earthen storage) (Morton 1982). Drum corrosion was the worst at the drum-tarp interface where condensate could form; however, even at this interface the drum corrosion (non-pitting) rate was found to be only one (1) mil per year. Corrosion within the module was negligible.

2. Airborne radionuclide contamination is expected to be minimal during Phase I retrieval. During the pilot retrieval, no airborne radionuclide contamination was found at either retrieval site. Air sampling, conducted through the trench module riser pipes prior to drum retrieval, detected no airborne contamination.

3. No airborne release of hazardous gases or other hazardous materials is anticipated during Phase I retrieval. Hazardous gases, including hydrogen, or hazardous materials were not detected at the pilot retrieval sites. Gas sampling conducted via the trench riser prior to TRU drum retrieval provided a simple, inexpensive method for data collection. The riser sampling helped bound pre-start conditions and provided hazardous/explosive gas and radionuclide information.

4. As found during pilot retrieval, the condition of the module should be dry and cool during Phase I retrieval. Pilot retrieval found no puddling of water in the drum modules as a result of the collection of tarp condensate.

5. Soil contamination by radionuclides or hazardous materials is not expected to be widespread, if it is present at all. Sampling results during pilot retrieval indicated no soil contamination by radionuclides or hazardous materials.

6. Ultrasonic testing to provide drum wall thickness data for quantitative assessment of drum corrosion is unnecessary, slow, and costly. The pilot retrieval discovered one drum with a pinhole, even though ultrasonic testing showed that the metal area around the hole was sound. The small hole may be due to pit corrosion, or it might reflect a pre-existing condition.

7. The safety authorization basis for Phase I retrieval should make use of existing documents and should be written as broadly as possible to allow for maximum flexibility during retrieval operations. The pilot retrieval project SAR (Joyce and Harker, 1993) was written very conservatively, thereby limiting the work scope that could be performed. This SAR, which was costly in terms of time, effort, and money, was a very limited use document.

8. Uncovering drums with shovels was labor intensive and required too much time. Mechanical means of removing the major portion of soil from covering drums is recommended for future retrieval.

9. The GPR used to assess distances to drums being retrieved gave poor results and should not be used in Phase I retrieval. Data gathered from GPR showed it to have negative field variance (i.e., the GPR gave distances that were much less than those actually measured in the field) ranging from -27 percent to -100 percent. The GPR was of little 
use in locating drums to be retrieved. Probing for drum tops and actual measurements of drums were the methods finally used to locate drums.

10. Phase I retrieval should include a re-assay to verify which drums are TRU and which are LLW. A re-assay of retrieved drums was performed during the pilot retrieval, and the assay results were compared to the assay values recorded for the drums when they were placed in storage in 1978 . When compared to the 1978 assay values, the plutonium reassay values taken in 1994 ranged from $+42 \%$ to $-46 \%$ of the original for drums containing 146 to 180 grams.

11. The work procedures should control the work activities without being so specific as to hamper work steps. The work procedures for pilot retrieval were too specific and limiting.

12. Continuous air monitoring service should be incorporated into future TRU Drum Retrieval activities involving excavation. During the pilot project, supplemental continuous air monitoring units were placed to measure any increase in radionuclide emissions beyond the background established for the burial grounds. The two units were placed east and northeast of the retrieval sites to assure downwind coverage. Although no increase in any radionuclide above background was detected, the units provided an increased measure of protection and advanced warning.

13. A mock-up of a drum module was used as part of the training for the pilot retrieval project. By beginning the Phase I project with the retrieval of the uncovered drums at the west end of trenches 01,20 , or 29 , the training for the Phase I retrieval staff can take advantage of the opportunity for on-the-job training. Except for the removal of the soil covering of the trench, the removal of these drums will simulate TRU drum retrieval utilizing the same personnel, retrieval equipment, and drum assay equipment.

14. The retrieval of uncovered TRU drums should be a standard burial ground operation. As such, retrieval should be included as an ongoing activity and bounded within the standard burial ground documentation.

15. Retrieval activities should include contingency planning for such events as discovery of a higher frequency of unvented drums than what might normally be expected.

\subsection{LANL TRU RETRIEVAL}

The information in the following section was gathered during two visits to LANL to obtain information concerning the Transuranic Waste Inspection and Storage Project (TWISP) retrieval, storage, and drum venting/purging activities presently being conducted. The first trip, in July 1998, was documented separately in a letter report (Demiter, 1998). Findings from the second trip, in June 1999, are incorporated into this document.

\subsubsection{Background}

Between 1970 and 1988, LANL placed 16,600 drums in 20-year retrievable storage on TRU pads 1,2, and 4. All drums were unvented. The drums were mainly 55 -gallon drums that had a rigid 
90-mil polyethylene liner placed inside the drum. The top of the liner either snapped on or screwed on. The liner was used to protect the inner surface of the drum from the waste form.

The TRU storage pads provided ground-level storage on asphalt. Drums were stacked four and five high, usually surrounded by fiberglass-reinforced plywood (FRP) or metal boxes, and covered with four feet of earth. The covered TRU pads were mounded above ground level, unlike the below grade asphalt pad storage at Hanford.

The LANL TRU storage pads are classified differently from those at Hanford. When the RCRA Part A and interim Part B permits were submitted to the New Mexico Environmental Department (NMED) in 1988, the TRU drums in 20-year retrievable storage were described as being in an active storage configuration. Therefore, the LANL retrievably stored drums as well as any associated activities to retrieve the drums after 1988 were governed by appropriate RCRA regulations.

In 1989, as retrieval activities at DOE sites began to increase, LANL indicated that technology developed by other DOE sites would be applied to the retrieval of stored TRU wastes from pads 1,2 , and 4 . Hanford became the lead site in the development of drum venting and the preparation of documentation required for the retrieval of TRU drums. LANL followed the retrieval progress of other sites and developed a generic TRU program.

In 1992, LANL decided to conduct a small sampling of TRU drums stored on pad 2, and sixteen (16) drums were retrieved in April of that year. One of the drums had a small pinhole and was left at the site. In May 1992, NMED conducted an audit of the LANL TRU pad storage and found the drum with the pinhole, which had not been overpacked. NMED found several other violations of RCRA regulations and concluded that LANL was not in compliance with RCRA. NMED issued a Notice of Deficiency, and LANL was fined $\$ 1.7$ million for non-compliance to RCRA hazardous, confinement, and inspection requirements for "stored" TRU-mixed wastes. The NMED fine was later reduced to $\$ 750,000$.

LANL developed an action plan and schedule for compliance with RCRA. The LANL TRU retrieval project was placed under a Consent Order Agreement to comply with RCRA regulations and remove the 16,660 drums from TRU pads 1,2, and 4 within five years. The LANL contacthandled retrieval project is known as the Transuranic Waste Inspectable Storage Project (TWISP). The title of the project indicates that the wastes are to be retrieved and placed in inspectable storage, but that no processing of the wastes is to be conducted.

The scheduled TRU retrieval activities supported the following milestone completion dates:

- Retrieve 4,880 unvented drums and 161 FRP boxes from TRU pad \#1 by September 30, 1998.

- Retrieve 4,540 unvented drums and 51 FRP boxes from TRU pad \#4 by September 30, 2000 .

- Retrieve 7,000 unvented drums from pad \#2 by September 30, 2003.

The schedule also included milestones to wash and vent drums and to place them in inspectable RCRA storage. 


\subsubsection{Development}

The LANL TRU Retrieval Project was instituted as a new burial ground activity, separate from standard burial ground operations. Therefore, the project did not take advantage of existing TRU documentation or activities (e.g., shipping, handling or movement of TRU wastes) conducted within Technical Area 54 at LANL. In this aspect, the LANL TRU retrieval project development differed greatly from the SRS retrieval project (see Section 3.3.2.).

Initial retrieval at LANL was conducted in an enclosed 300-foot fabric dome structure at pad \#1. The dome structure was designed with HEPA filtration to control contamination and dust. The project also anticipated retrieving drums that were in poor condition, and initially estimated that 50 percent of the retrieved drums would require overpacking. After soil removal, drum retrieval continued as follows:

1. Containers from the stacked array were removed with a multipurpose vehicle.

2. Drums were overpacked as required.

3. Drums were shipped to drum cleaning and venting.

4. Drums were cleaned.

5. Drums were vented.

6. Real time radiography (RTR) of drums was performed at a mobile unit.

7. Drums were placed in RCRA-compliant storage domes.

To assure safe operations, the project operations staff was supported by project-specific safety, industrial hygiene, and health physics staff members. The original plan was to move the dome structure from pad \#1 to pad \#4 once pad \#1 retrieval was completed, and to pad \#2 once pad \#4 retrieval was completed. The retrieved drums were to be transported approximately $1 / 4 \mathrm{mile}$ to the venting facility, which was also a fabric dome structure.

During FY 1991 and FY 1992, LANL was not involved in the drum venting development being conducted at SRS and Hanford. After the NMED Compliance Order was issued in 1993, however, LANL began serious development of a drum venting system. LANL drum venting concerns paralleled those of SRS because both sites used a rigid 90-mil polyethylene liner in the drum. LANL subsequently teamed with SRS to develop a filter-drill bit assembly for drilling the drum lid and 90-mil liner and removing a gas sample.

The Drum Venting System (DVS) was developed at LANL to provide for venting of retrieved drums. The DVS design incorporated several Hanford drum venting concepts: drum drilling, drum seal, multiple-cycle nitrogen drum back-fill capability, evacuating the drum drill area, and other design concepts co-developed with SRS or Hanford. The DVS inter-site design reviews were conducted during FY 1994 with the 50 percent design review conducted in January 1994, and the final design review conducted in May 1994.

During the 1994 TRU Partnership Meeting, LANL reported that funding for FY 1995 was reduced and would delay or impact the following aspects of the LANL TRU retrieval project:

1. TRU retrieval waste analysis and characterization would have to rely on mobile equipment because funding was not available to construct facilities.

2. Construction of new TRU storage facilities would be delayed. 
3. The Waste Acceptance Plan (WAP) submitted in 1994 was rejected by NMED and a Notice of Deficiency was issued by NMED. With limited funding, LANL could not resubmit the plan until March 1995.

4. The majority of the DVS would be fabricated on site (at LANL) because of high bids and reduced funding.

5. The reduced funding would slow fabrication of the DVS.

6. The entire TRU retrieval project would be delayed jeopardizing completion of NMED/DOE/LANL milestones for TWISP project completion in 10 years.

The DOE funding cuts for FY 1995 and subsequent project delay greatly disturbed NMED. The TWISP project began negotiations with DOE to restore FY 1995 funding. LANL also received new management with a renewed focus on project completion. DOE funding was reestablished for the project, the WAP was approved, and the DVS neared completion by the close of FY 1995.

During FY 1996, LANL finished construction and installation of retrieval, venting, and storage domes. The DVS was completed and testing begun. Preparations were underway for the TWISP Operational Readiness Review (ORR) for the Category 2 storage buildings, retrieval, and venting.

The ORR generated several findings concerning Category 2 storage and the DVS. The DVS was found to lack quality assurance documentation in several fabrication and testing areas. The DVS would require another $\$ 500,000$ and six months to correct the findings. The Category 2 storage buildings took 13 months to complete readiness.

During the ORR process LANL developed a very open working relationship with DOE and NMED. LANL had an open-door policy for DOE, NMED, and the Defense Nuclear Facilities Safety Board (DNFSB). Daily calls were made to the organizations concerning TWISP status, problems, and proposed solutions. In this manner, LANL developed a very trusted relationship with the agencies, which still exists today.

LANL held weekly meetings to update management on TWISP ORR progress, and DOE and NMED were invited to these weekly meetings. LANL also developed weekly employee meetings whereby all progress, developments, or needed changes could be heard and assessed first hand. Using this approach, the TWISP staff developed a very cohesive working relationship.

LANL finally demonstrated readiness in all phases of the TWISP project and began TRU retrieval from Pad \#1 on March 25, 1997.

\subsubsection{Lessons Learned}

LANL completed retrieval of TRU Pad \#1 on August 18, 1998, six weeks ahead of the September 30,1998 milestone. The unvented drums and boxes stored on Pad \#1 had been placed in retrievable storage from May 1979 through December 1984. Approximately 60 weeks of retrieval were required to retrieve the 4,880 drums and 161 boxes stored on the pad, which represents an average retrieval rate of 84 containers/week. Currently, LANL is retrieving wastes from TRU Pad \#4. The scheduled milestone completion date for retrieval of Pad \#4 is September 30,2000 . 
The LANL findings for TRU Pad \#1 and \#4 retrieval follow.

1. No airborne contamination was found despite the fact that LANL retrieved some highly loaded drums that contained $>300$ grams $\mathrm{Pu}$.

2. The drums were in very good condition after being in earth-covered storage for 17 years. Only 126 of the 4,880 retrieved drums (less than three percent) required overpacking due to visible signs of leaks, severe corrosion, or physical damage. (The initial project estimate was $50 \%$.)

3. LANL demonstrated unvented drums could be retrieved and transported some distance (drums were moved approximately 1/4-mile from retrieval to venting) without incident.

4. No hazardous gases or materials were detected at the retrieval site.

5. Up to 26 percent hydrogen was detected in the unvented drums during the venting operation. The hydrogen could be safely purged from the drums with the DVS nitrogen purge system. Each nitrogen purge cycle of the DVS took about 10 minutes and, similar to SRS experience, reportedly lowered the hydrogen level within the drum about $12 \%$ with each cycle.

6. The DVS was able to vent drums at a rate 150 percent above the design requirement. Four thousand $(4,000)$ retrieved drums were vented in 15 months. Because the DVS exceeded its drum venting design rate, another venting machine was not procured, which reduced project costs.

7. Criticality concerns are predicated on the assumption that drum integrity is lost. Because the retrieved drums were in good condition and a basis for structural collapse of drums or drum arrays was not found, criticality was not an issue.

8. The drum corrosion inhibitor, applied to the drums prior to storage, worked very well. The inhibitor, an oil-base product, was easily removed using a non-hazardous, citrusbased cleaner.

9. The project specific SAR developed for TRU retrieval at LANL was very restrictive and allowed little flexibility in retrieval operations. As a result, 24 unreviewed safety question determinations (USQDs) were identified during the first year of retrieval operations. LANL personnel estimated that these USQDs cost the project approximately $\$ 1.2$ million, including documentation, training, and USQ closure.

10. PPE (masks) may have been useful for protecting against dust (high silica content) from retrieval operations, but were not required for radionuclide particulate filtration because no airborne contamination was detected. Although the dust problem has improved in the open-air retrieval currently being conducted at pad \#4, the requirement for mask use is still in place. Again, the masks are driven by the presence of silica, not by any airborne radioactive contamination.

11. About 90 percent of LANL's retrieved drums are mixed waste, with waste codes established and applied before the drum was buried. 
12. The GPR conducted at the site, prior to retrieval, had poor accuracy and was of little use. Probing was used to locate drums prior to excavation.

13. The SKY TRAK ${ }^{\circledR 3}$ was an excellent choice for retrieval equipment. All vehicle attachments were used during retrieval: the forklift attachment, the front-end loader, bucket, the personnel basket, and the drum grabber. The vehicle was also capable of a 30 -foot reach.

14. Removing soil from atop the module was difficult in a dome structure (even though LANL removed about two feet of the soil overburden prior to placing the retrieval dome). The structure inhibited free movement of the vehicle removing the soil and trapped vehicle emissions, which necessitated constant monitoring by an industrial hygienist. Personnel work was restricted due to vehicle emissions, as tailpipe or exhaust tubes to vent the exhaust outside were sometimes impractical for use. A general safety problem resulted from the use of the retrieval dome.

15. Several FRP boxes were ruptured or broken open. This was attributed to poor box design and the inability of the boxes to withstand the soil loading and/or boxes were damaged during handling and placement.

16. The loose material from breached containers did not spread contamination. Only 1055 gallon drums were required to repackage loose material and locally contaminated soil from breached containers (mainly boxes).

Prior to subsequent retrieval activities at pad \#4, LANL removed the four feet of soil cover from the TRU pad. The soil removal was made possible because no airborne radionuclide contamination or hazardous contamination was found during TRU pad \#1 retrieval. The pad \#4 drums remained covered with a tarp until retrieval activities began in November 1998.

The entire retrieval of pad \#4 will be conducted in open air with no dome structure. Following completion of pad \#4 work, retrieval will begin at pad \#2. Retrieval of pad \#2 containers will also be conducted in open air.

Several activities conducted during LANL retrieval can be applied to future Hanford retrieval. Applicable findings and recommendations include the following:

1. Hanford retrieval should use versatile retrieval equipment, such as the SKY TRAK ${ }^{\circ}$. The SKY TRAK ${ }^{\circledR}$ retrieves drums using a drum grabber attachment. In addition, the SKY TRAK ${ }^{\circledR}$ equipment can be modified to perform the following tasks:

- pick up boxes or plywood with its fork attachments,

- remove soil from atop the stacked drums with the front-end loader attachment,

- carry two employees in the personnel basket attachment to inspect drums,

- remove plywood, or remove soil from top tiers of stacked drums, and

- maintain the required trench side-wall slope of $1.5 \mathrm{H}$ to $1.0 \mathrm{~V}$ with the tilting front-end loader.

\footnotetext{
${ }^{3}$ SKY TRAK is a registered trademark of Sky Trak International, Inc., a subsidiary of OmniQuip International, Inc.
} 
2. The safety authorization basis for Phase I Retrieval Project should make the maximum use of existing documentation and should be written as broadly as possible to allow for maximum flexibility during retrieval operations. LANL found that the development and review time of a project standalone SAR made it difficult to complete in a timely manner. In addition, LANL found changes, in the form of USQDs, were very costly and time consuming.

3. Based on the LANL experience, the drums to be retrieved during Phase I retrieval at Hanford are expected to be in good condition. LANL found few retrieved drums in poor condition after 17 years in earthen storage. The drum storage configuration and arid conditions at the Hanford site and LANL are similar, with the exception that Hanford drums are below grade. Hanford will be retrieving drums stored for approximately that same time.

4. Open-air retrieval should be used for Phase I retrieval at Hanford, and little to no airborne contamination is expected as a result of retrieval operations. Experience led LANL to switch to open-air retrieval. This decision was supported by findings of minimal drum corrosion and the lack of airborne contamination during the retrieval process, which included the retrieval of drums containing over 300 grams of $\mathrm{Pu}$. No problems with open-air retrieval have been experienced at LANL.

5. Drums stacked five high should present no additional problems for Phase I retrieval at Hanford. Like LANL, Hanford has drums stacked five high in three modules of 218-W$4 C$, Trench 04. LANL used a SKY TRAK ${ }^{\circledR}$ vehicle to remove stacked drums safely. In addition, no need to walk on modules during retrieval was demonstrated.

6. Hanford should cultivate and maintain a very open working relationship with regulatory and oversight entities. The LANL retrieval effort benefited from the strong relationship developed with the local DOE office, NMED, and the DNFSB.

7. Hanford should pattern its documentation on the LANL documentation developed during the TWISP project, as practical. This documentation is very similar to that required for the Hanford TRU retrieval project development.

8. Hanford will need to evaluate dust generated during retrieval of covered drums. LANL found that PPE was not required for radionuclide protection, but full-face masks provided useful protection from dust particulates.

9. When unvented drums are retrieved at Hanford, the Hanford-developed CVS should be evaluated for use and determination of drum venting rate. The drum venting experience from LANL indicates one venting machine can keep pace with retrieval needs.

\subsection{SRS TRU RETRIEVAL}

The following section is based on information concerning the TRU drum retrieval and venting/purging activities at the SRS "E" burial grounds that was gathered in April/May of 1997 (Demiter, 1997) and updated with SRS personnel in June 1999. 


\subsubsection{Background}

SRS began segregating TRU wastes from other radioactive wastes in 1970 following Atomic Energy Commission (AEC) Immediate Action Directive 0511-21 (AEC 1970). The TRU wastes at SRS were further separated by placing $<0.5$ curie wastes on earthen storage pads and $>0.5$ curie wastes in metal culverts or caissons (called casks at LANL). This was done because most of the retrievably stored TRU wastes at SRS are Pu-238, unlike LANL and Hanford TRU wastes which contain primarily Pu-239.

As at LANL, the SRS TRU drums stored on pads were unvented. SRS drums also had a rigid 90mil polyethylene liner placed inside the drum. The polyethylene liner was in two parts that either screwed or snapped together. The liner was to provide protection to the drum inner surface from waste forms.

The practice of storing unvented TRU wastes drums on earth-covered pads continued until 1985.

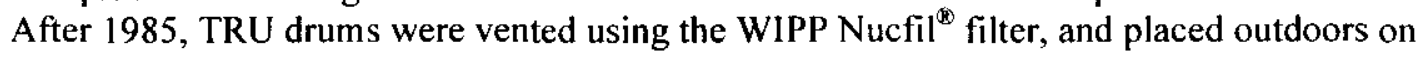
concrete Pads 7 through 13. Over the years, the vented drums collected water through the vent filter. The drums were radiographed, dewatered, and removed to covered storage during the early 1990s.

The remaining 8,810 unvented drums under earthen cover on TRU Pads 2 through 6 became the focus of the SRS TRU program. Like LANL and Hanford, SRS had conducted several activities to assess the drum conditions. SRS had buried metal coupons early in the TRU program, and corrosion data was taken at intervals. When compared to LANL and Hanford, drums buried at the SRS site were expected to show accelerated corrosion due to the abundant rainfall and more acidic soil.

Between FY 1988 and FY 1994, SRS developed several programs to focus on remote handling, characterization, and the processing of retrieved wastes. SRS also worked with LANL to develop a lancet drill bit/filter assembly to drill through the unvented drum lids and 90 -mil polyethylene liners. The hollow lancet would also pull a drum head-gas and liner gas sample in the same manner as the Hanford CVS. When the TRU funding from DOE-HQ dropped in 1995, most of these programs ended.

\subsubsection{Development}

In late 1994, SRS began an aggressive TRU retrieval project with a milestone of January 19,2000 to complete retrieval of the 8,810 unvented drums from the five TRU pads. SRS planned to conduct the project in phases and take credit for past TRU activity and operations conducted on the site. The retrieval of TRU drums was developed as a compilation of activities already conducted at the burial grounds as standard burial ground operations. The TRU retrieval methodology was accepted in 1995 , after 1.5 years of development.

The following rationale was presented to demonstrate that retrieval of the TRU drums was a composite of several activities already being conducted as standard burial grounds operation at SRS and that TRU drum retrieval would require only minor changes to current operations. 
1. The TRU Waste Facility report for the retrieval of the 8,810 drums was written and approved (Perella, 1995). The conclusion of the report was that the TRU retrieval project encompassed many elements of existing burial ground operations and should continue as outlined.

2. The venting and purging of 600 TRU unvented drums to gain data and to test the Nuclear Filter Technology, Inc. (NFT) venting unit was proposed. The activity was evaluated as less than hazard Category 3 . Meeting established design safety criteria, in conjunction with established SRS safety documentation, was justification that neither a Readiness Self-Assessment nor an ORR would not be required.

3. An Independent Scientific Peer Review (ISPR) was conducted (discussed below).

4. The TRU Retrieval Project was incorporated into the Basis for Interim Operation.

5. Meetings began with the State of South Carolina to (a) establish baseline soil sampling for site release and (b) provide a certified laboratory listing for soil analysis.

6. It was determined that a graded approach to DOE Order 5480.31, Startup and Restart of Facilities Operational Readiness Review and Readiness Assessments, would be applied.

7. SRS established an "open door policy" for DOE and the State of South Carolina whereby the agencies could walk in and review documentation of the project at any time.

The SRS project maintained that most retrieval hazards were already bounded by existing work conducted as standard burial grounds operations. Because SRS contended that TRU retrieval held no unbounded or new hazards, a graded approach to each element of retrieval was proposed.

SRS developed a criteria-weighted evaluation system for all aspects of the project. To gain acceptance of the project approach and to dispel concerns posed by the SRS Citizens Advisory Board, SRS established a national ISPR to evaluate the project. The ISPR supported the SRS TRU retrieval project approach and made the following conclusions:

1. Treatment technologies to treat TRU wastes will not be available for 10 to 14 years.

2. The soil-covered drums are corroding and should be moved to safer storage.

3. Assessing the soil-covered drums now is a preventive measure that deals with one of the highest near-term safety concerns at SRS.

4. The risk associated with retrieving and re-packaging the drums is well within the range of acceptable activities at SRS, which was directed at higher activity wastes than found in the retrieval drums.

5. The TRU waste drum retrieval project should proceed.

The SRS TRU project encompasses retrieval, venting, and subsequent RCRA-compliant storage of the TRU drums. The project is conducted at the Solid Waste Management "E" Area facilities and uses existing TRU-approved storage. After a successful venting demonstration to established 
criteria, the venting system was approved for TRU retrieval use. Following proof-testing of the venting system, retrieval documentation was written to define and govern the mode of retrieval.

SRS acquired the services of NFT to supply the venting machine. NFT developed a venting machine very similar to LANL and installed a HEPA filter train at the discharge. SRS installed the NFT venting machine and began the venting test in March of 1996. The system performed to established operating and safety procedures. In December 1996, the venting of the 600 drums was complete.

SRS began development of the retrieval criteria and documentation in 1995. An alternative study outlined retrieval activities to be conducted. SRS received overview and recommendations to continue retrieval activities as defined in the study, including retrieval in a dome structure, use of HEPA ventilation for the facility, and use of an inner retrieval face containment. The project began procurement of required equipment for the retrieval of TRU drums.

The ISPR completed its review of the TRU Retrieval Project in December 1995 and indicated that the retrieval of TRU drums was well within the bounds of normal burial ground operations. After the ISPR review, the project began to set methodology to retrieve drums. The project also submitted changes throughout 1995 to remove original retrieval design criteria supported in the alternative study. The removal of the design criteria was supported by the following factors:

1. Theoretical data was used to set original criteria, and recent activities had supplied actual data, which resulted in the removal of several uncertainties.

2. Employee experience removed many perceived safety concerns.

3. Excess equipment was postulated as the cause of several safety accident scenarios, and the project decided to delete unneeded equipment and procure multi-use vehicles.

SRS supplied supporting documentation to demonstrate that some of the original design criteria were not needed and did not improve safety. In some cases, the added criteria actually worsened safety. The following retrieval criteria were removed in this process:

1. Several pieces of large retrieval equipment were deleted. The project opted to use one forklift with a front-end drum grabber to retrieve drums.

2. The criterion to overpack all retrieved drums was deleted. Retrieval of test drum coupons provided the data needed to support this deletion.

3. The inner retrieval face containment (environmental control) was removed. Safety accident frequencies were reduced based on hydrogen concentration found in the vented test drums and drum coupon corrosion data. The new data supported the removal of the inner containment control.

4. The dome HEPA filtration system removal was supported by actual data reported in Item 3 above.

5. The RUBB Building Systems (RUBB) retrieval domes also were not required to supply a contamination control barrier. 
Since SRS had already ordered and received two RUBB domes, HEPA filter systems, and the inner retrieval face containment system, a return of the products was not possible. Orders for several large pieces of equipment were canceled. The RUBB domes were installed over the first two TRU retrieval pads as weather covers only. The inner retrieval face containment system and HEPA filtration units were never installed or put in service.

\subsubsection{Lessons Learned}

SRS completed the management review of the TRU Retrieval Project in January 1997 and began the retrieval of unvented drums of TRU in January 1997. Table 3-1 summarizes the SRS drum retrieval campaigns. As of June 15, 1999, a total of 8,250 drums had been retrieved over a 30 month period. The original milestone was to complete TRU drum retrieval from all 5 pads by September 2000; the new milestone is to complete the project by September 1999.

Table 3-1. TRU Drum Retrieval Campaigns at SRS

\begin{tabular}{|c|c|c|c|c|}
\hline $\begin{array}{c}\text { Storage } \\
\text { Pad }\end{array}$ & $\begin{array}{c}\text { Retrieval } \\
\text { Conditions }\end{array}$ & $\begin{array}{c}\text { Drum Placement } \\
\text { Dates }\end{array}$ & $\begin{array}{c}\text { Number of } \\
\text { Drums Retrieved }\end{array}$ & $\begin{array}{c}\text { Retrieval } \\
\text { Campaign Dates }\end{array}$ \\
\hline 6 & RUBB cover & Prior to 1985 & 1,933 & $1 / 97-8 / 97$ \\
\hline 4 & RUBB cover & $1975-1981$ & 1,959 & $8 / 97-12 / 97$ \\
\hline 5 & Open air & $1975-1981$ & 2,357 & $5 / 98-9 / 98$ \\
\hline 2 & Open air & $1974-75$ & 893 & $11 / 98-3 / 99$ \\
\hline 3 & Open air & $1977-78$ & 1,108 of $1,661^{*}$ & $3 / 99$ start \\
\hline
\end{tabular}

As of $6 / 15 / 99$

All drums from the five storage sites are designated as TRUM waste and are moved to RCRAcompliant storage pads. These drums will be stored at SRS until WIPP gets the dispensation to accept mixed waste. No drum processing facilities are planned at SRS.

SRS retrieves 40 to 60 drums per workday using one 10-hour work shift for retrieval and venting per day. The retrieval crew is composed of four employees: one radiation monitor, one operator to run the forklift to move and load drums, one operator to do the paperwork, and one operator to clean and label drums. Heavy equipment operators are also used to remove earth from the top of the storage pad.

SRS retained the original NFT venting machine following the test venting of 600 drums. The NFT venting machine was used to vent all retrieved drums until a second NFT machine was purchased and installed in June 1997. The two venting machines are able to keep pace with the SRS drum retrieval.

The following findings were made during SRS TRU drum retrieval:

1. Drums stored retrievably under earthen cover, for up to 24 years, were in very good condition, and there has been very little corrosion. Only 16 of the first 6,253 unvented TRU drums retrieved required overpacking. Twelve drums were overpacked due to corrosion, which occurred primarily in the bottom 4 inches of the drum. 
2. Unvented drums can be transported over a substantial distance (approximately $1 / 2 \mathrm{mile}$ from the SRS retrieval site to the venting building) without incident and without causing further gas generation.

3. During gas sampling, some unvented drums were found to contain hydrogen in excess of the lower explosive limit (LEL). SRS found hydrogen concentrations of up to 26 percent from the first retrieval site, and they report up to 60 percent hydrogen concentrations in one waste stream at the last site.

4. No loose or airborne contamination was detected at retrieval. No PPE was required for radionuclide control.

5. One piece of retrieval equipment (forklift with drum grabber attachment) was adequate for stacked drum retrieval.

6. The small crew of four employees was able to exceed original retrieval goals by 100 percent.

7. No hazardous gases (including hydrogen) or materials were detected in the ambient atmosphere during retrieval at the three sites.

8. Open-air retrieval of TRU drums can be conducted with a minimal work stoppage due to weather. (Note that 1997 was one of the wettest winter and spring at SRS.)

9. Two drum venting machines were required to keep pace with SRS drum retrieval.

10. It was agreed that several original design criteria (HEPA filtration, overpacks, dome covering, retrieval face containment, extra large equipment), removed from the project as unnecessary, would have hindered completion of the project.

11. The controls placed on the project were sufficient to demonstrate that TRU drum retrieval, transportation, venting, and subsequent storage could be accomplished safely in an open-air atmosphere without jeopardizing any burial ground operations standards.

12. No contamination has been found at any site. The drums do contain $90 \mathrm{mil}$ polyethylene liners.

13. SRS had to move boxes and casks in order to retrieve the drummed waste. High dose readings of $600 \mathrm{mR}$ at contact were associated with some of the casks, and some boxes and casks were moved to high-radiation storage.

14. No retrieved TRU drums have gone through RTR or assay yet. SRS maintains drums with their original assay value.

Several of the activities conducted at SRS during the development and execution of the TRU Drum Retrieva! Project may be applied to future Hanford TRU drum retrieval. Note that many of these activities are in agreement with the LANL TWISP findings as well. Findings and recommendations that may be applied to TRU retrieval at Hanford include the following: 
1. Phase I retrieval of TRU drums at Hanford does not require an enclosure. Retrieval experience gained at SRS led to the conclusion that open-air retrieval was more efficient, cost effective, and safer than retrieval within an enclosure. SRS found open-air retrieval could be conducted within existing burial ground operational limits.

2. Hanford should rely on one piece of retrieval equipment that is chosen for its adaptability and ability to meet specific retrieval site needs. SRS found that one piece of retrieval equipment was sufficient for all of their drum retrieval needs.

3. Hanford should use visual inspection to verify drum integrity. SRS found that the condition of drums retrieved from a 20 to 25 -year storage under earthen cover was very good, and that wall measurements were not needed to confirm sound drum integrity.

4. The SRS TRU retrieval project planning was based on the premise that retrieval activities are bounded by existing burial ground operations. A similar planning base should be adopted at Hanford.

5. SRS found that extensive training for the retrieval staff was not required, because the activities associated with the retrieval of TRU drums did not represent a significant departure from normal burial ground activities. For the same reason, specialized training should not be not needed for Phase I retrieval of uncovered TRU drums at Hanford.

6. Based on the retrieval experience at SRS, open-air retrieval is not expected to be compromised by radiological work control criteria (wind speed, temperature, and drum moisture). These criteria are the same at SRS, LANL, and Hanford. 


\subsection{OPERATIONAL APPROACH}

This section provides a general overview of Phase I TRU retrieval as well as a discussion of the basic steps necessary to retrieve TRU waste drums from the SWBG. Key retrieval activities include historical record review, removal of suspect-TRU waste drums from storage modules, verification assay, venting (as necessary), and transportation to the CWC, WRAP, or a final disposal trench in the SWBG.

The information presented in this section represents current planning efforts. Alternative approaches may be possible depending on changes in funding availability and/or other drivers. Several alternative approaches are discussed in Section 5.0.

\subsection{GENERAL OVERVIEW}

The overall approach selected as most likely for success, given project constraints that include limited funding and storage space, is to perform retrieval using a dedicated crew for a few months a year. Such a retrieval campaign would be done during a time when the weather is amenable to working outdoors, while avoiding the very busy summer months of July, August, and September. Although an initial retrieval campaign will occur in August-September 1999, it is assumed for the purposes of this plan that retrieval will be done either in the fall (October-November) or during the spring (March-June). The schedule, cost estimate worksheet, and Basis of Estimates (Appendices A, B, and C, respectively) show when each retrieval campaign will occur and how many drums will be retrieved during each.

The first drums to be retrieved will be the exposed (not covered with soil) drums in the $218-\mathrm{W}$ $4 \mathrm{C}$ burial ground, Trenches 1,20 , and 29. These three trenches contain about 1500 exposed drums. Retrieving these drums will be the scope of the retrieval effort for the first two years.

Following the retrieval of the uncovered drums, excavation will be necessary for continued retrieval of the TRU drums in earthen storage. The decision of whether to continue retrieval of buried drums in Trench 1,20, or 29, or to excavate and begin retrieval in Trench 4 will be made based on experience gained during the first two years of retrieval. It should be noted, however, that the full scope of Phase I retrieval, 10,000 drums, cannot be accomplished without retrieving some of the drums in Trench 4.

Retrieved drums will be assayed in the $218-\mathrm{W}-4 \mathrm{C}$ burial ground, using mobile assay equipment. The results of the assay will determine if a drum can be reclassified as LLW because it falls below the TRU activity limit of $100 \mathrm{nCi} / \mathrm{g}$. Drums that are reclassified as LLW waste will be staged nearby, paperwork will be updated to show that they are LLW, and they will be reburied in a trench with other LLW. Drums that assay as TRU waste will be moved to CWC for storage until such time as WRAP is ready to process them in preparation for shipment to WIPP.

\subsection{RECORDS REVIEW}

Before physical retrieval of the waste, a detailed review of existing waste records, similar to that done for the TRU drum relocate projects in FY96 and FY97 (Irwin, 1997), will be conducted. The reviewer will search available records such as the Solid Waste Information and Tracking System (SWITS) database, burial records, location maps, and supplemental generator records 
(discussed in more detail in Section 6.6.1). The purpose of the search is to divide the trench modules into waste streams with similar characteristics. As the module is retrieved, the drums will be staged to facilitate assay. It is anticipated that minimization of drum movement will be an important issue due to space constraints on the pad.

The review of historical records will also allow the retrieval team to identify drums that pose potential additional hazards to workers or that require special handling. Examples include drums with high gram quantities of fissile material, drums with high dose rates, drums containing animal carcasses, overweight drums, or drums from waste streams with a high potential for containing hazards such as pressurized containers (paint cans) etc. These drums can be flagged early in the process to avoid surprises during retrieval. (Specific criteria for the safe handling, movement, storage, treatment, and disposal of containers during Phase I retrieval are given in the safety basis documentation (see Section 6.2).)

Records review for the first uncovered drums to be retrieved has begun with FY99 funding.

\subsection{RETRIEVAL ACTIVITIES}

Current plans are for retrieval to begin with the exposed drums (i.e., those without soil cover) located in 218-W-4C burial ground Trench 1, Trench 20 , or Trench 29 . The recommended starting location is Trench 29 , which contains approximately 1000 uncovered drums (of a total 1500 in the burial ground). Trench 29 also has the smallest number of boxes. Boxes will not be retrieved as part of Phase I retrieval, but may need to be relocated within the trench to allow access to the retrievable drums. After the uncovered drums are removed from Trench 29 , the remaining uncovered drums in $218-\mathrm{W}-4 \mathrm{C}$, located in Trench 1 and Trench 20 , will be retrieved.

Although Trench 29 is the currently preferred starting point for retrieval, several other options are acceptable. For example, the detailed records review or operational needs may dictate that retrieval begin in Trench 1 or Trench 20 rather than in Trench 29. It may also be possible to schedule retrieval to occur simultaneously in all three trenches. Table 4-1 shows the numbers of drums and boxes currently stored in each trench.

Table 4-1. Phase I Retrieval Trench Statistics

\begin{tabular}{|l|c|c|c|c|c|}
\hline Container Type & Trench 1 & Trench 4 & Trench 20 & Trench 29 & Total \\
\hline Uncovered Drums & 351 & 0 & 168 & 1012 & 1531 \\
\hline Total Drums & 5080 & 9856 & 613 & 2544 & 18,093 \\
\hline Number of Boxes & 70 & 38 & 78 & 10 & 196 \\
\hline Total Containers* & 5150 & 9894 & 691 & 2554 & 18,289 \\
\hline
\end{tabular}

* This total may contain a small number of containers that do not fit into the categories above.

When retrieval of the exposed drums is completed, Phase I retrieval will begin the removal of the currently buried drums. Retrieval of these drums will not be possible without excavation. Because the SWBG Interim Safety Basis (ISB) currently prohibits excavation for retrieval, changes will be needed to the SWBG ISB to allow excavation. Changes to the SWBG safety authorization basis may also include changes to the Criticality Prevention Specification (CPS). These changes are being planned to coincide with the completion of exposed drum retrieval. Readiness activities will be conducted in accordance with Hanford Site procedures (e.g., FDH, $1998 \mathrm{~b}$; WMH, 1997) prior to beginning drum excavation activities. 
The best location to begin retrieval of drums requiring excavation will be dependent upon the retrieval or processing commitments in place at the time. If the commitment is still in place to retrieve the approximately 10,000 drums envisioned under former project W-113, then the retrieval of covered drums should occur at Trench 4, as that is the only location with sufficient quantities of waste to meet this commitment. If the commitments are reduced, or are tied to production rates, it may be more efficient to complete retrieval of Trench 29 . Completely retrieving the stored drums from Trench 29 is preferred from an operational standpoint as this makes the trench available for other uses. Retrieval could also be continued in Trench 20 or Trench 1, but would likely not add operational efficiencies, due to relatively large numbers of boxes that must be relocated. In addition, if continued retrieval occurs in Trench 1, it cannot proceed beyond Module 4 due to the location of 12 drums containing high levels of $238 \mathrm{Pu}(235$ to 590 grams). These drums will not be retrieved until Phase II Retrieval (Project W-221).

\subsubsection{Pre-Start Steps}

The following activities need to occur before retrieval of drums:

1. Review records for drums to be retrieved (as discussed in Section 4.2 above).

2. Conduct general housekeeping and cleanup in the trench where retrieval is to occur. Remove tumbleweeds, drifted sand, etc. Stage supplies as needed.

3. Identify the retrieval site with appropriate fencing, roped area, and signs, and provide access control, etc.

4. Mark coordinates of most westerly location of drums (necessary for Trench 4 only).

5. Set up the mobile assay system. There are at least three possible locations: in Trench 29, in Trench 24, or on the unused area between Trench 7 and Trench 14. Any or all of these locations may be utilized based on a number of factors as discussed in Section 4.4 below. Because drums that assay as LLW will be disposed of in a trench identified for permanent disposal, the assay system should be placed between the retrieval site and the LLW disposal trench in order to provide efficient drum flow to and from the unit. The mobile assay system will be trailer-mounted and self-contained. No utility services will be required.

6、 Identify and mark drum inspection areas (including radiological survey, visual check of drum integrity, and labeling), drum overpacking area, staging areas for drums awaiting assay, staging areas for TRU drums to be shipped, and staging areas for LLW prior to disposal.

\subsubsection{Retrieval without Excavation}

With the exception of the verification assay and any drum venting activities that may be required (see Sections 4.4 and 4.5), the retrieval of uncovered drums will be performed in accordance with existing SWBG procedures and practices. A flow diagram for the retrieval of uncovered drums is provided in Figure 4-I. 


\section{Figure 4-1. TRU Retrieval Flow Diagram}

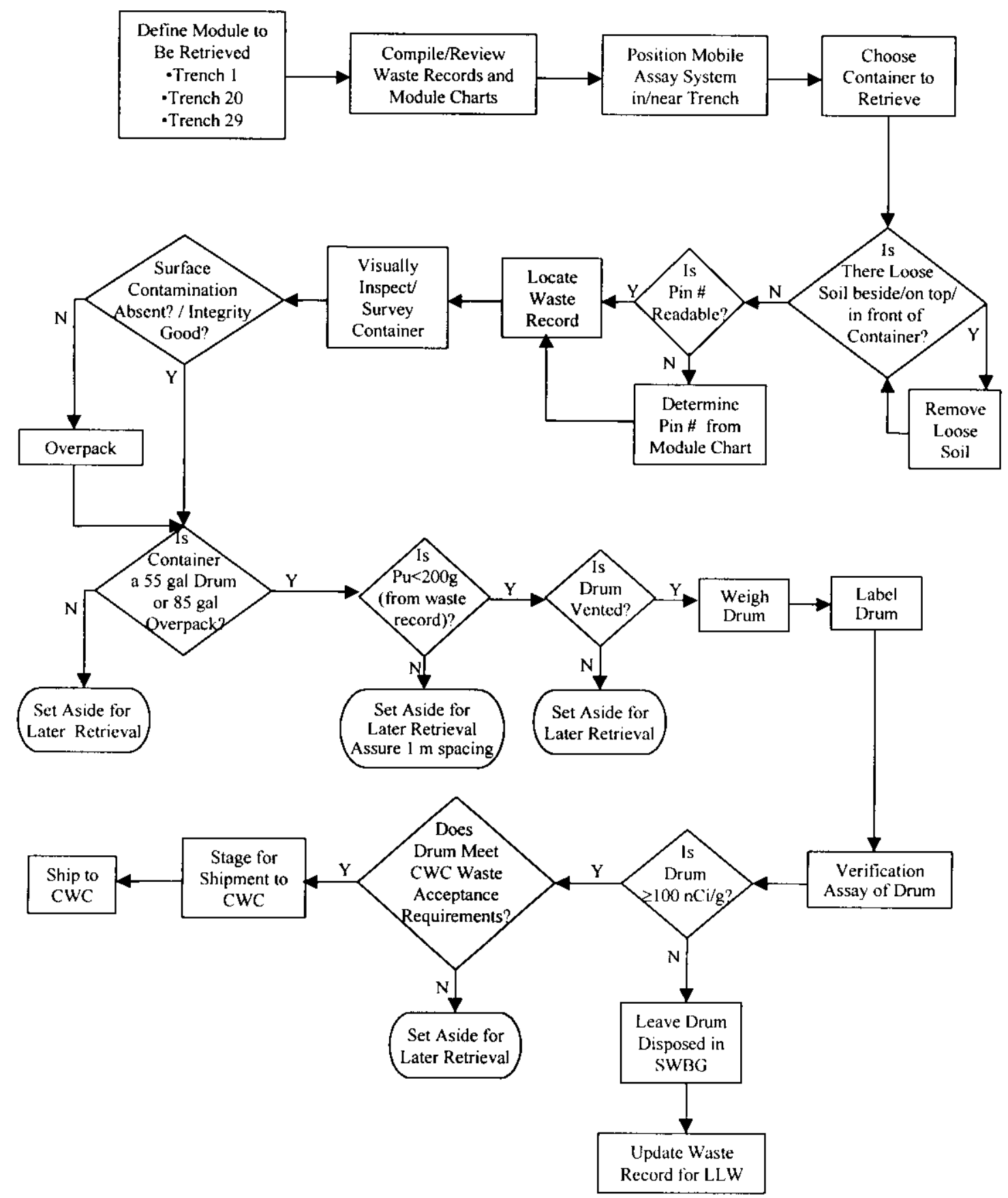


The following general activities should also be considered during the retrieval of uncovered drums.

1. A Waste Profile Data Sheet will be generated for the retrieved TRU drums. The form will record pertinent drum data from SWITS and other historical records as well as data about the retrieved drum collected during the retrieval process. New data may include information such as drum number, weight, size, surface dose rate, retrieval date, drum condition, verification assay results, and final disposition.

2. At the retrieval lay-down area, the drum will be surveyed, weighed, labeled as required, and the retrieved drum data sheet will be completed.

3. During retrieval, drums may first need to be raised slightly to inspect the drum bottom, or turned to inspect the rear face.

4. If the drum is damaged or visual inspection notes that drum integrity is suspect, the PPE requirements will be adjusted as directed by the Radiological Work Permit. If needed, the damaged area will be wrapped with plastic sheeting or otherwise secured for contamination control. An 85-gallon overpack will then be positioned as close as possible to the damaged drum, then the drum will be lowered into the overpack.

5. When boxes are encountered in the storage module, they will be visually inspected in the same manner as drums, and removed to a designated lay-down area at the trench perimeter.

6. Job planning will include measures to be taken when a high dose rate drums job is encountered. These measures include the attachment of lead shielding to the drum and placing the drum in an overpack. The additional shielding will be recorded on the retrieved drum data for along with both pre- and post-shielded dose rates.

7. Drums with high TRU gram loadings will be repositioned to provide safe storage in accordance with the SWBG Criticality Prevention Specification.

8. The retrievably-stored drums to be retrieved in Phase 1 were not regulated under RCRA at the time they were accepted at the SWBG. To ensure that the project will not be violating federal and state statues, TRU drums for which records indicate a high probability of containing hazardous chemicals will be segregated and remain on a retrievable pad in the burial ground pending acceptance into a TSD facility.

9. Phase I retrieval activities will not remediate the burial grounds. If contaminated soil is encountered during retrieval, the PPE will be adjusted as directed by the Radiological Work Permit. Small amounts of incidental contaminated soil may be placed in drums or boxes, and the packages will be staged as appropriate while the paperwork required for newly-generated waste is developed. As necessary, larger areas of contamination will be fixed and the area posted as a soil contamination area.

10. Unvented drums (i.e., those with no Nucfil ${ }^{\circledR}$ or ventclip) will be assayed using the mobile assay system. Drums that assay as LLW will be staged with other LLW drums to be returned to a disposal trench. Drums that assay as TRU will be vented using the CVS or a similar device. The vented drums will then be staged with the other TRU waste for shipment to CWC. 
11. Plywood removed from the modules will be stacked, then reused for stacking LLW drum tiers.

12. Drums will be transported from the retrieval trench to the mobile assay lay-down area within the $218-\mathrm{W}-4 \mathrm{C}$ Burial Ground using a forklift or transport truck.

13. At the assay lay-down area drums may be segregated into 55-gallon, 85 -gallon, shielded 85-gallon drums, etc., to facilitate assayer operations.

14. Drums will be assayed and moved out of the assay unit. The verification assay will be a LLW-TRU partition assay. Drums will keep the original assay value shown as they were placed in retrievable storage. TRU drums will be staged for shipment to $\mathrm{CWC}$ or another approved Treatment, Storage, and/or Disposal (TSD) unit. LLW drums will remain disposed in the SWBG.

15. TRU drums will be shipped to CWC in accordance with waste acceptance process developed for the retrieved drums (see Section 4.8).

16. SWITS database information will be amended to reflect drum movement locations, drum overpacking, drum content changes (if shielding is added), dose changes, etc.

\subsubsection{Retrieval with Excavation}

The general activities discussed for retrieval of uncovered drums in the previous section are also applicable to retrieval of covered drums (i.e., drums currently in earthen storage). In addition, the following activities will be necessary during the retrieval of covered drums.

1. For excavation at Trench 4 , the soil on the trench approach ramp will be removed by front-end loader. The soil will be piled nearby for future use, or may be moved elsewhere in the SWBG for use as backfill material. Soil removal will continue until the west face of the module is exposed.

2. The soil overburden will be removed from the drums beginning at the west-end of the stack. This will be done using a front-end loader or a SKY TRAK ${ }^{\circledR}$-type vehicle (see Section 3.3) with the front-end loader attachment. Excavation can be performed from the asphalt pad or from the north or south rim. Operation of excavation equipment is usually limited to greater than one foot away from waste, with the remainder of the excavation being done using vacuum equipment or by hand.

3. Overburden soil will generally be removed one module at a time. In addition, the reach on the excavation equipment may limit the amount of soil that can be removed at one time. If supplemental safety analysis allows, the amount of overburden removed at one time may increase with experience. LANL was able to remove the overburden from an entire trench, about 4,500 drums, at one time.

4. Soil adjacent to the trench (north and south) will be removed by backhoe or a SKY TRAK $^{\otimes}$ type vehicle. Soil removal will be conducted so that the correct trench wall slope ( 1 vertical to 1.5 horizontal) is maintained. 
5. Industrial safety and health physics personnel will assess the retrieval site conditions and provide approval to proceed with retrieval.

6. Once soil is removed from the module and the safe slope established, personnel will roll the tarp back to expose the trench drum face and remove the plywood from the top of the module.

\subsubsection{Retrieval Volumes/Annual Campaigns}

A number of factors influence how much waste to retrieve in a given year. These include anticipated funding levels for retrieval, anticipated funding levels and associated volumes for TRU waste processing, CWC storage capacity, WIPP shipment schedule, retrieval crew availability, and relative fractions of waste that assay as LLW and TRU. This plan seeks to achieve a balance among these factors in order to determine the volume of waste to be retrieved in a given time year.

To utilize personnel resources most efficiently, annual retrieval campaigns will last from a few weeks to a few months. These campaigns will occur during months when the weather is amenable to outdoor operations (i.e., typically not December or January) and will avoid peak operational periods in the SWBG (i.e., July, August, and September). This plan assumes a single annual retrieval campaign to occur each spring beginning in April 2000. Depending on operational readiness, however, retrieval activities could occur in short campaigns distributed throughout the year, at the discretion of the operations manager.

The minimum operations crew required for retrieval of the uncovered drums consists of three operators and one Health Physics Technician (HPT). In addition, an operations team lead must be immediately available, and intermittent assistance from Industrial Safety/Industrial Hygiene and a Teamster will be required. For retrieval of drums requiring excavation, a heavy equipment operator will be needed. As retrieval progresses, crew requirements will be reevaluated to determine the optimal number of operators and/or HPTs.

The number of drums to be retrieved each year is shown in Table 4.2. Plan numbers are approximate and have been established based on the factors discussed above. Dramatic changes in WRAP processing rates or WIPP shipment rates may necessitate changing the number of drums retrieved in a given year. Similarly, if the fraction that assays LLW is significantly higher or lower than $50 \%$, the retrieval rates may need to be adjusted.

Table 4-2. Phase I Annual Retrieval of Suspect-TRU Drums.

\begin{tabular}{|c|c|c|c|}
\hline $\begin{array}{c}\text { Fiscal } \\
\text { Year }\end{array}$ & $\begin{array}{c}\text { Number of } \\
\text { Drums }\end{array}$ & $\begin{array}{c}\text { Probable } \\
\text { Trench(es) }\end{array}$ & Status \\
\hline 1999 & 200 & 29 & Uncovered \\
\hline 2000 & 400 & 29 or 1 & Uncovered \\
\hline 2001 & 700 & $1,20, \& 29$ & Uncovered \\
\hline 2002 & 1,000 & $1,4,20$, or 29 & Covered \\
\hline 2003 & 1,700 & $1,4,20$, or 29 & Covered \\
\hline 2004 & 2,000 & $1,4,20$, or 29 & Covered \\
\hline 2005 & 2,000 & $1,4,20$, or 29 & Covered \\
\hline 2006 & 2,000 & $1,4,20$, or 29 & Covered \\
\hline TOTAL & 10,000 & & \\
\hline
\end{tabular}




\subsubsection{Other Considerations}

Equipment necessary for Phase I retrieval will include a forklift in locations where drums are no more than three high (Trench 20 and Trench 29) and a SKY TRAK ${ }^{1}$-type vehicle for locations where the drums are more than three high (Trench 1 and Trench 4). The SKY TRAK ${ }^{\circledast}$ vehicle allows visual inspection of the integrity of higher drums prior to moving them. Additional resources that will be used during retrieval activities include overpacking supplies, labeling supplies, and contamination control materials. Depending on the results of the Notice of Construction for radioactive air emissions, additional air monitoring equipment may be required for venting operations and covered drum retrieval.

\subsection{VERIFICATION ASSAY}

All retrieved waste drums will be assayed to determine whether the drum is TRU or LLW. Waste containers that are confirmed to be $<100 \mathrm{nCi} / \mathrm{g}$ will remain disposed as LLW. Waste containers that are confirmed to be $>100 \mathrm{nCi} / \mathrm{g}$ will be staged for transfer to $\mathrm{CWC}$.

Depending on the size and portability of the chosen assay equipment, the system could be set up on the asphalt pad in the trench, or at a central location within $218-\mathrm{W}-4 \mathrm{C}$. Ideally, it will be located as close to the retrieval operation as possible, without being so close that it hinders the operation or that background radiation from the drums in the trench interferes with obtaining accurate assay results.

As confidence with the verification assay operation and results increases, it may be possible to designate some drums as TRU without the need for the assay step. In order to do this a gram/weight factor will need to be developed. This factor will be applied to highly loaded suspect TRU drums with relatively low weights, as recorded on existing drum records. The application of this factor will allow selected drums to be designated as and staged immediately for transport to the CWC.

The assay system most capable of determining the TRU/LLW threshold for the majority of the expected waste drums will be selected. However, there may be some waste matrices or radioisotopes for which the chosen system is not capable of performing at the desired sensitivity. In these instances, a conservative approach will be taken to assure that potential TRU drums are not disposed of as LLW.

Procurement of mobile assay vendor services is simplified by doing retrieval in campaigns. A separate procurement can be prepared for each campaign, if necessary, or a single procurement can cover multiple campaigns. A sample statement of work for a vendor to perform drum assay has been included in Appendix A.

The chosen vendor will mobilize their equipment, assay the designated drums over a relatively short amount of time, and then leave. A typical vendor can assay and provide the results for between 10 and 20 drums during the workday. It is important that the detailed planning and scheduling of each campaign take into account the rate at which the assay system is capable of processing drums. 


\subsection{CONTAINER VENTING AND HEADSPACE GAS SAMPLING}

Vent clips were required on all TRU drums after about 1979. Although drums packaged before 1979 are not expected during the first few years of Phase I retrieval, it is conceivable that an occasional unvented drum will be encountered. This could be because the vent clip was never installed or, if a vent clip was installed, it has somehow broken off, making it impossible to verify that the drum is vented. In either case, TRU drums that cannot be verified as vented, will be vented prior to storage in CWC and processing at WIPP.

Container venting, and other aspects of handling unvented drums are addressed in the Unvented Drum Handling Plan, (McDonald and DeRosa, 2000). This plan was developed as a result of discovering a larger number of unvented drums than was previously expected during retrieval of uncovered suspect-TRU waste. The plan recommends use of a commercial vendor to provide drum-venting equipment as needed to support retrieval.

Headspace gas sampling is not currently planned as part of retrieval; however, the possibility of sampling newly vented drums for hydrogen, using a real-time flammable gas detector is being considered. Headspace gas sampling, as required for WIPP certification, will not be conducted at the retrieval site, but will be conducted after the TRU drums are characterized at WRAP.

\subsection{TRANSPORTATION}

Vehicular movement of waste containers within the SWBG during Phase I retrieval will occur in accordance with existing SWBG procedures. The staging of individual waste containers within the retrieval trench as well as movement of these containers between trenches in the burial ground will generally be done using a forklift. If a larger batch of similar waste containers require movement between trenches, for example 55-gallon drums of LLW being relocated within the disposal units, a truck may be used.

The movement of multiple TRU drums within the SWBG for staging or to another solid waste facility (e.g., CWC or T Plant) will be accomplished using a covered van or other vehicle as permitted by the governing Safety Analysis for Packaging (SARP) (see Section 6.2.2). The number of TRU drums that may be transported in a single-shipment is contingent on the FGE loadings of the drums. Administrative controls that are commonly employed when moving TRU drums onsite include the use of an escort, reduced speed limits, and two-way communication capability.

\subsection{WASTE ACCOUNTING}

Each suspect TRU drum to be retrieved has been assigned a unique Package Identification Number (PIN). If the PIN is missing or illegible, a new PIN will be assigned. As each drum is retrieved it will be given a barcode label that corresponds with the PIN. This barcode will be used to track the drum anytime it moves from one location to another.

A checklist will be developed for each drum that assays as TRU. This checklist takes information in the SWITS record, along with any supplemental information from the original burial record, and compares it with facility acceptance limits for the receiving facility. The completed checklist, new assay results, and any other paperwork that is generated (e.g., radiation surveys, 
etc.) during retrieval of each drum will be added to the file for that drum. This file will be used to build the AK package when the drum is prepared for shipment to WIPP. For the drums that assay as LLW, new assay results will be appended to the record along with a letter or other such documentation to show that the drum has been redesignated as LLW.

There may be instances where the original drum label or marking is unreadable and the PIN cannot be identified. When this occurs it should be possible to identify the drum using the module charts and SWITS location records. As a last resort, the drum will be given a new identification number and processed and tracked like other drums.

\subsection{WASTE ACCEPTANCE PROCESS}

Drums that are determined to be LLW by the verification assay will be transferred to dedicated trenches within the same burial ground. Current waste acceptance criteria for the SWBG will not be applicable to confirmed LLW since the waste is previously disposed.

Drums that assay as TRU will be retrieved from the SWBG during Phase I and transported to the CWC for storage. These drums will remain in storage until they are accepted at the WRAP facility, where they will be processed for shipment to WIPP for disposal. Some of the retrieved drums may also need to be vented at T-Plant prior to being shipped to the CWC. In order to assure that the retrieved drums can be stored and/or treated in a safe and compliant manner at other Hanford TSD facilities, a Project-Specific Alternative Waste Management Plan is being prepared. This alternative plan, which requires approval by the Washington State Department of Ecology, is in accord with the provisions of the Waste Analysis Plans for the CWC (FDH, 1999a) and WRAP (FDH, 1999b). This plan will document the basis for determining that there is sufficient knowledge for safe storage of the retrieved drums and will provide the specific process by which retrieved TRU drums will be accepted at Hanford Site solid waste facilities.

Because the Phase I retrieved wastes are not newly generated, the plan for acceptance of the retrieved TRU drums at solid waste facilities will be based on assuring compliance with the safety authorization basis and permits for the accepting facility. The acceptance process will rely on the historical records and process knowledge available for the waste as well as data gathered during the retrieval process. Section 6.6 discusses the characterization documentation that will be key to the waste acceptance process.

Because all TRU wastes drums will eventually be transferred to $\mathrm{CWC}$ and WRAP, Acceptable Knowledge (AK) requirements pursuant to WAC 173-303-300, as specified by the CWC and WRAP Waste Analysis Plans, will be implemented. The CWC and WRAP Waste Analysis Plans acknowledge that "waste analysis requirements could be met through application of acceptable knowledge when such knowledge provides sufficient information to ensure that waste will be stored properly... Acceptable knowledge... (includes) waste previously disposed of before the effective date of the regulation that has been or will be retrieved for storage at CWC/WRAP, and for which adequate information has been obtained to ensure proper storage at CWC/WRAP."

The historical data available for each TRU drum in combination with the data collected during the retrieval process will form a strong basis for the application of AK requirements. The Waste Profile Data Sheets, which will be used to document the information gathered for and obtained from Phase I retrieval activities, will form the basis for the creation of an AK documentation package. 
All of the suspect-TRU waste in the SWBG met the solid waste acceptance criteria in effect at the time that it was accepted for storage/disposal. Although many of these criteria have remained the same since this waste was generated, modification and additions to Hanford site waste acceptance criteria have been made over the years to reflect new regulatory requirements (Duncan, 1995). Prior to being shipped for final disposal at WIPP, all retrieved TRU wastes will be processed at WRAP, where they will be characterized to meet WIPP waste acceptance criteria. 


\subsection{ALTERNATIVES CONSIDERED}

During the development of this plan, alternative approaches to three key activities were considered. The following section discusses the rationale behind choices to begin retrieval with newer drums, to acquire drum-venting equipment, and to conduct retrieval operations without a containment structure.

\subsection{DRUM AGE}

The original Phase I retrieval (Project W-113) was to have begun, not with the oldest drums, but with some of the newest drums. The rationale for this approach is that the experience gained during the retrieval of less complicated configurations of TRU drums is desirable prior to retrieving more difficult configurations, remote handled drums and boxes, and containers with questionable structural integrity. There is much to be gained, especially in the area of worker safety, by beginning retrieval with a known set of conditions (i.e., the newest drums).

The opposing argument is, of course, that the older drums should be retrieved first, since they have a higher chance of being breached and posing a hazard to human health and the environment. By retrieving the older drums first a release to the environment might be prevented.

During this Phase I retrieval planning effort, the original decision was deemed to be valid. The first year of excavation retrieval (FY 2002) is expected to provide a wealth of data on covered drum condition. At that point in time a decision should be made whether to continue with retrieval of the newer drums or whether resources should be reprioritized to begin early retrieval of the older drums.

\subsection{DRUM VENTING}

Because Phase I retrieval will begin with newer drums that were vented prior to storage/disposal in the SWBG, a relatively small number of drums are expected to need venting during the next few years. The CVS should be capable of handling these drums. However, when retrieval begins on drums placed in storage prior to 1979 , the number of drums that need to be vented will increase significantly. Prior to retrieval of these older drums, consideration should be given to acquiring the Drum Venting System (DVS) from LANL. LANL's retrieval activities are scheduled for completion in FY2004, after which the DVS may be available as excess equipment.

\subsection{RETRIEVAL UNDER A CONTAINMENT STRUCTURE}

Because Hanford has many days that are not amenable to performing outdoor work (due to wind, snow, heat, etc.), consideration was given to providing some sort of cover over the retrieval location. Although a structure with the rigor of the original Project $\mathrm{W}-113$ was not considered feasible, there are many types of covers that could be used.

A cover would provide a few advantages. Retrieval could continue in wind, rain, or snow, and the cover would provide some shade, relief from summer heat. The cover could also provide a form of containment in case of airborne radioactive contamination. However, lessons learned 
from retrieval activities at LANL and SRS (see Section 3.2 and 3.3, respectively) show that covered retrieval has some definite disadvantages. These include decreased equipment and personnel mobility, difficulty in dispersing dust from the excavation, and potential for buildup of vehicle exhaust fumes.

Retrieval activities at LANL and SRS reported a significant absence of airborne contamination. If the experience during Hanford retrieval is similar, and there is no reason to believe that it should be otherwise, then there is no need for an expensive cover over the retrieval trench. After some experience is gained doing buried drum retrieval at Hanford, the need for a containment structure over the retrieval site can be reevaluated, and a cover can be designed if necessary.

Experience from other sites indicates that about 40 to 50 drums can be retrieved in a day, although only about 15 to 20 can be assayed in a day. At the retrieval rates proposed in this plan, about 50 working days/year will be required for retrieval; there should be no problem finding 50 days with mild enough conditions for outdoor work. The verification assay of the drums will require approximately twice as many processing days, but, unlike retrieval, assay work can continue in mildly windy conditions. Much of the time spent doing assay is spent waiting for the machine to perform the count, and the operator can spend this time in a controlled environment rather than in the trench with the assay equipment. Because the assay work is not as sensitive to weather conditions as are the other facets of retrieval, it should not be difficult to find enough working days to accomplish the given scope outdoors. 


\subsection{DOCUMENTATION}

This section focuses on the documentation that either effects the Phase I TRU Retrieval Project or is affected by it. Document updates, revisions, and changes that may be required are discussed, as applicable.

\subsection{NATIONAL ENVIRONMENTAL POLICY ACT (NEPA)}

Over the past 20 years, several NEPA documents have considered the activities associated with TRU waste retrieval.

- In the Final Environmental Impact Statement: Disposal of Hanford Defense High-Level, Transuranic and Tank Wastes, Hanford Site, Richland, Washington (HDW-EIS) [DOE 1987] Record of Decision (ROD) (53 Federal Register (FR) 12449, 1988), DOE determined that it would retrieve and process all TRU and suspect TRU waste that has been retrievably stored at the Hanford Site since 1970.

- In the Environmental Assessment: Solid Waste Retrieval Complex, Enhanced Radioactive and Mixed Waste Storage Facility, Infrastructure Upgrades, and Central Waste Support Complex (DOE, 1995), the DOE proposed to initiate retrieval activities in Burial Ground 218-W-4C, Trench 04 . The proposal included construction of support facilities as necessary to carry out the retrieval operations, and resulted in a finding of no significant impact (FONSI).

- The Final Waste Management Programmatic Environmental Impact Statement For Managing Treatment, Storage, and Disposal of Radioactive and Hazardous Waste (DOE 1997) examined the impacts associated with the management of radioactive and hazardous wastes (including TRU) throughout the DOE complex. The DOE issued the ROD on the treatment, storage, and disposal of TRU waste in the January 23, 1998 edition of the Federal Register.

- A NEPA screening has been performed (Appendix B) for the activities associated with the retrieval of the uncovered drums. It was determined that this retrieval effort has no effect on cultural or ecological resources, and is, in fact, implementing the HDW-EIS ROD, as well as the TRU ROD for the Waste Management Programmatic EIS.

Another screening should be performed prior to retrieval of the covered drums, since the excavation activities have the potential to effect local ecological resources. The continuation of retrieval activities should also be reevaluated upon issuance of the impending Hanford Site Solid Waste Environmental Impact Statement ROD, as it may affect the results of previous TRU waste decisions.

\subsection{SAFETY AUTHORIZATION BASIS DOCUMENTS}

The following safety basis documents are either directly applicable to Phase I retrieval or are substantially affected by planned retrieval activities:

- Solid Waste Burial Grounds (SWBG) Interim Safety Analysis (Bushore, 1998a) and the SWBG ISB (Bushore, 1998b) 
- Safety Analysis Reports for Packaging (SARPs) of Steel Drums (McCormick, 1998; Stevens, 1994)

- CWC ISB (Sargent, 1998; Ames and Bendixen, 1997)

- WRAP SAR (Weidert, 1997)

- T Plant ISB (Meyer, 1997)

The following sections discuss each of these documents and the revisions and/or supplements that may be required to accommodate planned retrieval activities.

\subsubsection{Solid Waste Burial Grounds Safety Basis}

The retrieval of the uncovered drums early in Phase I retrieval and the retrieval of the covered drums in the succeeding years are associated with slightly different hazards. For this reason, changes to the SWBG safety authorization basis (Bushore, 1998a and 1998b) should be performed in two stages: one to address the retrieval of uncovered drums and the other to address the retrieval of buried waste.

Because the activities planned for the retrieval of uncovered drums constitute standard activities for the SWBG, the SWBG safety basis currently allows retrieval of the approximately 1500 drums that do not require excavation. The SWBG safety basis does not currently address container venting operations, however, and an USQ evaluation will need to be performed prior to initiating this activity. The USQ will determine if the safety basis will need to be modified and the extent of such modifications.

Modifications to the SWBG safety authorization basis will be required prior to the excavation of buried drums. The SWBG ISB currently states that "Retrieval of buried TRU waste beyond the vented drums as analyzed in [WHC-SD-WM-SAR-058] will require approval of additional safety analyses that revise the Solid Waste Burial Ground authorization basis." The referenced document is the Final Safety Analysis for Contact-Handled Transuranic Waste Drum In Situ Inspection and Vented Drum Retrieval (Joyce and Harker, 1993). Thus, the existing safety basis will allow exhumation of about 100 buried drums, but the remainder can not be excavated without a specific modification to the ISB. These modifications are not necessary for the retrieval of uncovered drums, but are required before excavation of buried drums can occur.

\subsubsection{Safety Analysis Report for Packaging in Steel Drums}

Two SARPs for steel drums are currently in place. The SARP for 55 gallon drums (McCormick, 1998) has been recently updated, but is quite restrictive on TRU payloads. A revision (unrelated to the TRU retrieval effort) is currently being prepared to reevaluate many of these restrictions. A separate effort is being pursued to evaluate the existing 55 gallon SARP and the 85 gallon drum SARP (Stevens, 1994) to assure an approved safety authorization basis for the packaging activities associated with the TRU retrieval effort. This effort will include evaluation of the following items:

- Minor changes to the lifting requirements to allow greater operational flexibility 
- Methodology required for shipping unvented drums to T-Plant if necessary

- New tie-down analysis and potential use of stake-bed trucks

The initial retrieval campaign can begin, however, without the SARP changes discussed in the previous paragraph in place. This is possible because the drums will be moved within a given trench, or, if they moved to a different trench, the movements will remain within the SWBG. In both cases, no access to the road (in this case Dayton Ave.) will be required. When the retrieved TRU drums are moved to CWC for storage the applicable SARP will need to be followed or a road closure will need to be approved.

\subsubsection{Central Waste Complex Interim Safety Basis}

Only minor changes, if any, would be required to the CWC ISB to accommodate retrieval. These changes can be addressed at later stages of Phase I retrieval, as needed. Some examples of CWC restrictions that will need to be addressed and the extend of their effect on TRU drum retrieval follow:

- There is a 200 fissile gram equivalent (FGE) maximum for drums to be received at CWC. Less than one percent of the drums in Trenches 1, 4, 20, and 29 exceed this value.

- The maximum drum weight for receipt at $\mathrm{CWC}$ is $1,000 \mathrm{lbs}$. Greater than ninety-nine percent of drums in Trenches 1, 4, 20, and 29 meet this requirement. For the one- percent that do not meet the requirement, other plans must be made.

\subsubsection{Waste Receiving And Packaging Facility Final Safety Analysis Report}

The WRAP FSAR (Weidert, 1998) currently contains requirements that may restrict the acceptance of some retrieved drums into the WRAP facility. Analysis of these requirements and appropriate changes to the WRAP FSAR (or the Solid Waste Master SAR that is currently being developed) will need to be scheduled in time to facilitate the processing of these drums. Some examples of WRAP restrictions that need to be addressed and the effect on the processing of retrieved TRU drums follow:

- All TRU drums are required to be equipped with Nucfil ${ }^{\mathbb{1}}$ filters. Approximately $90 \%$ of vented drums in Trenches $1,4,20$, and 29 have vent clips, but not Nucfil ${ }^{(3)}$ filters.

- WRAP has a 35 dose equivalent curies (DE-Ci) maximum per drum. Approximately 11 percent of drums in Trenches 1, 4, 20, and 29 exceed this value.

- There is a 200 FGE maximum for drums to be received at WRAP. Less than one percent of drums in Trenches 1, 4, 20, and 29 exceed this value.

- There is a 177 FGE maximum for reprocessing in the gloveboxes. As many as four percent of drums in Trenches 1, 4, 20, and 29 may exceed this value.

- The maximum drum weight for receipt at WRAP is 1,000 lbs. Greater than ninety-nine percent of drums in Trenches 1, 4, 20, and 29 meet this requirement. For the one- percent that do not meet the requirement, other plans must be made. 
- There are strict limits on toxic materials allowed (Table 3-29 in Weidert, 1998). Because records on hazardous material are sketchy for drums generated prior to 1987 , it is difficult to estimate how many drums in Trenches 1, 4, 20, and 29 will not meet these requirements.

These issues need to be addressed before drums are moved to WRAP; however, retrieval of drums and movement to CWC can occur prior to revising WRAP's safety authorization basis.

\subsubsection{T Plant Interim Safety Basis}

The participation of T Plant and 2706-T in Phase I drum retrieval is expected to be minimal. The $T$ Plant Complex may participate in performing head gas sampling of retrieved drums as part of the WIPP certification, but this activity requires no changes to the T Plant ISB.

It is also possible that T Plant may be used for venting the previously unvented drums encountered during retrieval. Current plans call for venting activities to occur in the SWBG, as close to the retrieval site as is practical. However, if SWBG safety authorization basis changes become prohibitively lengthy, or if air permitting becomes too restrictive, consideration will be given to moving this activity to the T Plant complex. Both SRS and LANL have successfully moved unvented drums to another location to be vented. SRS ships unvented drums about $1 / 2$ mile from the retrieval site to the venting location, and LANL ships unvented drums about $1 / 4 \mathrm{mile}$. Both sites have shipped thousands of unvented drums without incident.

\subsection{RADIOLOGICAL WORK PROCEDURES}

Most uncovered drum retrieval will be conducted as part of normal SWBG operations, and existing Radiological Work Procedures (RWPs) will be used. An evaluation of the adequacy of the current RWPs will need to be performed based on the operating procedures for the mobile assay system and the container venting system. Either of these two operations may require a new RWP.

Retrieval operations that include excavation will likely require the development of a new RWP. RWPs to address contingencies (such as a breached drum) will be developed on an as-needed basis. For example, a contamination spread resulting from a breached drum will typically invoke some level of emergency response. When the contamination has been stabilized, then an RWP will be developed to govern cleanup activities.

\subsection{CRITICALITY PREVENTION SPECIFICATION}

There are a few drums in Trenches 1, 4, 20, and 29 that have a FGE loading greater than 200 . A criticality prevention specification (CPS) and special handling procedures will need to be written for these containers. A careful review of drum records will assure that none of these containers are encountered during retrieval, until such time as the proper procedures are in place.

See also Section 6.8.1.1 below. 


\subsection{AIR PERMITTING}

The initial retrieval activities for uncovered drums consist of the following steps:

- inspecting the drums;

- relabeling drums as necessary;

- assaying retrieved drums in the SWBG;

- moving those retrieved drums that assay as LLW to a LLW disposal trench for final disposal, and

- moving those retrieved drums that assay as TRU to CWC to await processing in WRAP.

No potential to increase air emissions is associated with any of these activities; therefore, there is no need for additional air permitting.

The venting of unvented drums, however, does have the potential to increase emissions to the environment and will require a notice of construction (NOC) (permit) for radioactive air emissions and an evaluation for toxic air emissions. A strategy for the required notice of construction (NOC), including source terms, potential to emit, maximally exposed individual, etc., is currently being developed (see Appendix C). Since it is expected that less than $1 \%$ of the Phase I drums will require venting, the source term is not large. If, for some reason, this strategy is not acceptable to the Washington Department of Health, consideration will be given to moving the venting activity to the T Plant Complex or another approved facility.

The excavation of buried drums has the potential to create significant air emissions and is considered a new activity from an air emissions standpoint. The development of air permitting documentation for excavation retrieval will need to begin in FY 2001 to support buried drum retrieval.

\subsection{WASTE CHARACTERIZATION DATA}

Waste characterization data for the suspect-TRU wastes in burial ground $218-\mathrm{W}-4 \mathrm{C}$ are both an important input to and output of Phase I retrieval.

- The initial review of historical records, discussed previously in Section 4.2, will allow similar drums to be batched for retrieval operations.

- Review of historical records allows early identification of drums that may pose potential hazards to workers or require special handling.

- Careful documentation of the data collected during both the records review and the retrieval process will provide the characterization data necessary for the subsequent storage and processing of TRU drums in accordance with the waste acceptance process (see Section 4.8).

- Data gathered during Phase I TRU retrieval will aid in the planning of subsequent TRU retrieval efforts. 
The following sections present a brief discussion of the documentation available for the initial records review, especially the SWITS database, as well as the proposed methodology to update the existing documentation with new data gathered during the retrieval process. Documentation of the data gathered from both historical records and retrieval is key to ensuring that retrieved TRU drums meet the waste acceptance criteria for safe and compliant storage at CWC as well as for processing at WRAP.

\subsubsection{Historical Records for Post-1970 Suspect-TRU Waste}

Existing records that may be consulted for use in the planning of retrieval operations include burial records and the SWITS database, process knowledge documents, and historical waste management documents. These records were created, in large part, to document compliance with the waste acceptance criteria in force at the time that the waste was generated and sent to storage/disposal.

\subsubsection{Burial Records and the SWITS Database}

Throughout the past forty years a number of documents and databases have been used to archive waste content data and track waste containers. The use of standardized burial records began about 1968, and, although the information included on them has changed over time, microfilmed copies of the original burial records are available for the suspect-TRU drums to be retrieved in Phase 1 . Records from the early 1970's include information on radioactive contents, drum weight, and generator. Later burial records contain physical content descriptions and, since 1987, information on the non-radioactive chemical waste constituents has been required.

The SWITS database is used to track the radioactive solid waste that has been buried or stored in the 200 Area burial grounds and waste storage facilities. Information on SWITS has been derived from the burial records. Information that can be tracked by SWITS for an individual waste container includes generator, container type and size, storage or burial location, radioactive contents, hazardous/corrosive contents, and waste form information.

\subsubsection{Process Knowledge}

Understanding the processes that generated the retrievably stored, suspect-TRU waste at Hanford provides additional waste characterization data. Waste characterization reports that include significant discussion of process knowledge are available for the largest generators of suspectTRU waste: the Plutonium Finishing Plant (Duncan et al., 1993), PUREX (Pottmeyer et al., 1993a), 231-Z (Pottmeyer et al., 1993b), the 325 Laboratory (Pottmeyer et al., 1993c), General Electric's Vallecitos Nuclear Center (Vejvoda et al., 1993), Babcock and Wilcox (Duncan, 1994a), and Westinghouse Advanced Reactor and Nuclear Fuels Divisions (Duncan et al., $1994 \mathrm{~b}$ ). As a group, these generators produced approximately $86 \%$ of the suspect-TRU waste in retrievable storage at the SWBG.

\subsubsection{Historical Waste Management Documentation}

All suspect-TRU waste to be retrieved was previously accepted into the SWBG under the waste acceptance criteria in force at the time the waste was accepted. The Hanford Site's historical waste acceptance criteria as well as former waste management requirements and waste handling and packaging practices may provide information of use in the planning of retrieval operations 
and in meeting waste acceptance criteria for the CWC, WRAP, and/or WIPP. These data have been documented in the Solid Waste Management History of the Hanford Site (Duncan, 1995).

\subsubsection{Documentation of Data Collected During Phase I Retrieval}

In addition to the historical information gathered for each TRU drum, data generated as a result of the retrieval process will be key to meeting waste acceptance criteria for safe storage in the CWC, processing at WRAP, and ultimate acceptance at WIPP. The following sections describe the data that will be routinely generated during Phase I and how those data will be documented.

\subsubsection{Verification Assay Results}

All suspect-TRU waste was accepted into the SWBG under the waste acceptance criteria in force at that time. Because of changes in the definition of TRU waste as well as the methods by which waste was determined to be TRU, however, some fraction of the waste initially disposed of as TRU is considered to be LLW under current definitions (i.e., the waste contains $<100 \mathrm{nCi} / \mathrm{g}$ ). The primary purpose of the drum assay step (see Section 4.4) is to verify the correct designation of each suspect-TRU drum as either LLW or TRU.

Drum assay results will be retained with the drum paperwork on a Waste Profile Data Sheet (discussed in the Section 6.6.2.2). In addition, the SWITS database will be updated to reflect the assay results and the final drum classification as either LLW or TRU.

\subsubsection{Waste Profile Data Sheets}

Information from the comprehensive records review as well as any new data collected during the retrieval process will be used to complete waste profile data sheets. The CWC waste acceptance personnel will review the data sheet per their WAC and document an independent decision regarding its acceptability for storage. Project scope will end once confirmed TRU wastes are transported to CWC.

\subsubsection{Updates to the SWITS Database.}

In addition to creation of Waste Profile Data Sheets, the SWITS database will be updated to reflect information gained during the retrieval process. Key information that will be recorded in SWITS will include, but not be limited to, the following:

- Changes in the storage or disposal location of a waste container. This includes waste in 55-gallon drums as well as other containers that may need to be moved to permit the retrieval of TRU drums.

- New waste type designations based on the verification assay results.

- Verification assay values.

- Surface dose rate.

- Drum weight. 
- Additions of vent clips and/or filter packs to the drums.

- Placement of a drum into an overpack.

\subsection{EMERGENCY PLANNING}

With the exceptions of drum venting and drum excavation, which are discussed below, the activities associated with Phase I retrieval are standard SWBG activities. Therefore, the types of accidents that can be encountered during retrieval of the uncovered drums are no different than the scenarios that have already been considered for the SWBG. No revisions to emergency planning documents (WMH, 1998) or bases (e.g., emergency action levels (EALs)) will be required.

When detailed planning of the container venting system is complete, analysis of the hazards associated with drum venting activities will need to be performed. Potential accident scenarios will then need to be assessed to assure that emergency planning efforts are adequate. At this time, however, there is little reason to believe that current facility EALs will be affected as a result of venting activities.

Evaluation of the hazards associated with burial ground excavation activities may also provide accident scenarios that have not been considered in current SWBG emergency plans. When detailed planning of excavation retrieval is complete, evaluation of the activities will need to be performed to assure that emergency planning is adequate to address potential accident scenarios.

\subsection{SAFEGUARDS AND SECURITY}

\subsubsection{Safeguards}

Drums retrieved during Phase I of the Hanford TRU retrieval project will be retrieved from four TRU trenches (Trench 01, Trench 04, Trench 20, and Trench 29) in burial ground 218-W-4C. The retrieved drums, which were placed in these trenches from April 1978 through February 1988, will typically be vented (contain a Hanford vent clip) and be contact-handled (CH). All four trenches have had drum and box placement mapping conducted as part of the 1994 Pilot TRU Retrieval Project or Project W-113.

Three safeguards concerns will require evaluation during Phase I Retrieval:

- criticality,

- special waste forms, and

- classified waste.

Each of these concerns is discussed in the sections below.

\subsubsection{Criticality}

All containers placed in the burial grounds retrievable storage from 1978 to 1990 have been reviewed for criticality concerns (WHC, 1994). As a result of this evaluation, restrictions were 
placed on the length of time drums of criticality concern could remain in earthen storage. Based on the expected lifetime of a drum stored underground, storage time was restricted to 18 years for painted drums and 20 years for galvanized drums. These time restriction limits are applicable to 36 "sequences" of high-Pu-content 55-gallon drums within the 218-W-4C trenches that are to be retrieved in Phase I. Drum sequences are defined as high-Pu-content if the drums are determined to collectively contain $1,500 \mathrm{~g}$ Pu within a 25 drum horizontal cluster.

The underground storage limits determined in the criticality evaluation (WHC, 1994) were based on the assumption that "long-term corrosion of the drums in underground storage could result in drum array collapse or leachout of TRU". The subsequent analysis of the buried drum arrays, however, was based on two erroneous inputs. First, the drum sequences were determined from shipping records rather than the drum stacking placement records, which reflect actual drum configurations. Second, the horizontal assessment of drum failure for "redistribution of fissile material contents" is not a viable assessment mode for "collapse and leachout of TRU" for vertically placed drums.

It should also be noted that the assumed rates for drum corrosion in the criticality evaluation may be overly conservative. The 1994 Pilot TRU Retrieval Project, which retrieved 55-gallon drums from Trenches 01 and 04 , found that drum corrosion was negligible after 14 years in underground storage. Of the 36 high-Pu-content sequences in $218-\mathrm{W}-4 \mathrm{C}$ burial ground, 24 of those sequences are contained in Trenches 01 and 04.

New corrosion data has also been obtained from the recent TRU drum retrieval projects at SRS and LANL. SRS has retrieved TRU 55-gallon drums that have been in underground storage from 1972, and LANL has retrieved drums from underground storage dating from 1975. Both DOE sites conduct a visual inspection of all drum surfaces for soundness. After retrieval, the drums are transported about $1 / 2$ mile in an open truck to the venting facilities. No incidents have occurred due to drum corrosion.

The criticality documentation should be updated to:

- extend the allowable underground storage time based on the new drum corrosion data from Hanford, LANL, and SRS;

- reevaluate the high-Pu-content sequences based on drum placement records; and

- present a viable drum-failure mode analysis based on vertical drum storage and the new drum storage data.

\subsubsection{Special Waste Forms}

Special high-risk wastes will be avoided during Phase I retrieval until further assessments can be conducted. Of specific concern is a group of 12 high- $\mathrm{Pu}^{238}$ drums. Drum placement mapping indicated these drums are located in $218-\mathrm{W}-4 \mathrm{C}$, Trench 01 , module 4 , tier 4 . The drums are distributed throughout the tier. The drums were shipped to Hanford from the Savannah River Plant for criticality testing. The material was considered Pu oxide scrap. The Pu oxide is triple contained, in two aluminum cans and a stainless steel pipe, and positioned in the drum using a drum-centering device. Each drum contains from 235 to $590 \mathrm{~g}$ of approximately 85 weight 
percent oxide. $\mathrm{Pu}^{239}$ fissile gram equivalent estimates, corrected to the year 2000, range from 153 to $373 \mathrm{~g}$. This waste form will not be retrieved during the Phase I TRU Retrieval Project.

\subsubsection{Classified Wastes}

Database entries indicate that no classified wastes were disposed of to the $218-\mathrm{W}-4 \mathrm{C}$ burial ground trenches. The SWITS database indicates the majority of classified wastes were placed in the 218-W-3A burial ground. Smaller amounts of classified wastes were placed in the $218-\mathrm{W}-$ $3 \mathrm{AE}$ and 218-W-4B (Trench 07 and Trench V-7) burial grounds. Future TRU drum retrieval, beyond Phase I, will require site evaluation and guidance from the site Safeguards and Security organization.

\subsubsection{Security}

With the exclusion of classified waste and special waste forms from the scope of the Phase I TRU Retrieval Project, no special security measures will be needed. It is anticipated that the retrieval will progress module by module within a trench, with LLW drums being moved to a LLW disposal trench and TRU drums being transferred to CWC at regular intervals. This regular movement of drums will not require security forces to escort/monitor drum transfers or conduct road closures. 


\subsection{BUDGET}

Table 7.1 provides a summary of the total estimated funding required for each year. The base funding figures are shown in the second column; the funding estimates in the third column were modified based on a systematic analysis of the project risk factors. Project risk may result from incomplete design, unforeseen and unpredictable conditions, or uncertainties within the defined project scope. These estimated costs, including those that include consideration of project risk, fall within the baseline case funding estimates for FY 1999 through FY 2004 in the WMH Priority Planning List.

Table 7-1. Estimated Funding Requirements for Phase I TRU Retrieval.

\begin{tabular}{|c|c|c|}
\hline Fiscal Year & $\begin{array}{c}\text { Base Funding } \\
\text { Requirement }\end{array}$ & $\begin{array}{c}\text { Funding Requirement } \\
\text { Including Project Risk } \\
\text { Factors }\end{array}$ \\
\hline 1999 & $\$ 410,000$ & $\$ 444,000$ \\
\hline 2000 & $\$ 1,042,000$ & $\$ 1,174,000$ \\
\hline 2001 & $\$ 1,580,000$ & $\$ 1,825,000$ \\
\hline 2002 & $\$ 1,527,000$ & $\$ 1,865,000$ \\
\hline 2003 & $\$ 2,425,000$ & $\$ 3,029,000$ \\
\hline 2004 & $\$ 2,801,000$ & $\$ 3,577,000$ \\
\hline 2005 & $\$ 2,801,000$ & $\$ 3,656,000$ \\
\hline 2006 & $\$ 2,754,000$ & $\$ 3,679,000$ \\
\hline Total & $\$ 15,340,000$ & $\$ 19,249,000$ \\
\hline
\end{tabular}

The derivation of the base funding costs presented in Table 7.1 is shown in a detailed cost estimating worksheet, which can be found in Appendix D. This worksheet breaks down the work into four activities spread over eight years: Pre-Retrieval Activities, Records Reviews, Uncovered Retrieval Campaigns, and Covered Retrieval Campaigns. 


\subsection{SCHEDULE}

A schedule of the retrieval campaigns as well as the number of drums to be retrieved during each campaign was presented previously in Table 4.2. A more detailed schedule of the key tasks/components required to accomplish retrieval is given in Appendix E.

The schedule provides for retrieval to be accomplished at a rate that provides a continual feedstock for WRAP processing, without retrieving drums at a rate so fast that CWC storage capacity is overwhelmed. The schedule attempts to minimize expenditures in FY 2000, when funding is most severely limited, while maintaining a sustainable level of retrieval. 


\subsection{CONCLUSIONS/RECOMMENDATIONS}

Phase I retrieval of post-1970 TRU wastes from burial ground $218-\mathrm{W}-4 \mathrm{C}$ can be done in a safe, efficient, and cost-effective manner. Initiating TRU retrieval by retrieving uncovered drums from Trenches 1, 20, and 29, will allow retrieval to begin under the current SWBG safety authorization basis. The retrieval of buried drums from Trenches 1, 4, 20, and 29, which will require excavation, will commence once the uncovered drum are retrieved. This phased approach allows safety analysis for drum venting and drum module excavation to be completed and approved before the excavation proceeds. In addition, the lessons learned and the operational experience gained from the retrieval of uncovered drums can be applied to the more complicated retrieval of the buried drums.

Precedents that have been set at SRS and LANL to perform retrieval without a trench cover, in the open air, should be followed. Open-air retrieval will result in significant cost savings over the original plans for Phase I retrieval (Project W-113). Based on LANL and SRS experience, openair retrieval will have no adverse impacts to the environment or to the health and safety of workers or the public.

Assaying the waste in the SWBG using a mobile assay system, will result in additional cost savings. It is expected that up to $50 \%$ of the suspect-TRU wastes will assay as LLW, allowing those waste to remain disposed of in the SWBG. Further processing, with its associated costs, will only occur to the portion of the waste that is verified to be TRU.

Retrieval should be done, to the extent possible, under the current SWBG safety authorization basis as a normal part of SWBG operations. The use of existing personnel and existing procedures should be optimized. By working retrieval campaigns, typically during the slow months, it is easier to coordinate the availability of necessary operations personnel, and it is easier to coordinate the availability of a mobile assay vendor. 


\subsection{ASSUMPTIONS}

A number of assumptions were necessary to develop this plan. Key assumptions are discussed below, along with the impact on the plan if the assumption is incorrect.

1. The DOE (and Ecology if necessary) will approve the Project-Specific Alternative Waste Management Plan that is currently being prepared. This plan allows the LLW fraction of the suspect-TRU to remain disposed of in the SWBG and the TRU fraction to be moved to CWC and, subsequently, to WRAP without further characterization. Full characterization of the TRU waste will occur at WRAP in preparation for shipment to WIPP.

This assumption is crucial to the success of the plan. To process the LLW fraction of retrieved drum as newly generated waste would prohibitively increase the cost of retrieval. To fully characterized the TRU fraction before sending to CWC and WRAP would also increase costs prohibitively. The WRAP facility was constructed to perform this characterization.

2. The TRU waste can be shipped to CWC without meeting the criteria for newly generated waste as specified in the Hanford Site Solid Waste Acceptance Criteria (FDH, 1998a). Retrieved waste can be safely shipped and stored based on the knowledge available, and receipt will be based on ensuring the requirements of the safety authorization basis and the permit for the CWC are met.

This assumption is also crucial. To meet the existing waste acceptance criteria would require a full characterization of the waste prior to receipt at CWC. However, this characterization cannot occur until WRAP has processed the waste.

3. A containment structure is not required for retrieval.

If a containment structure is found to be necessary to contain radiological releases or to provide a weather enclosure, the cost of retrieval will rise substantially. In addition to the cost of the structure, experience at LANL and SRS has shown that an enclosure limits the mobility of equipment and personnel as well as concentrates vehicular emissions.

4. Drums to be retrieved in Phase I are in good condition, and only a small percentage will need to be overpacked.

The cost estimating worksheet currently assumes that 5\% of the uncovered drums and $20 \%$ of the covered drums will require overpacking. Numbers different than this will change the costs, but should not hinder the overall project. If drums are found that are highly damaged. and accompanied by significant levels of radioactive contamination, this may significantly slow retrieval progress while contingency plans are developed.

5. Upon assay it will be found that approximately half of the drums assay as LLW.

The assumption of a 50-50 split between LLW and TRU waste is not crucial. Retrieval costs increase slightly with a higher percentage of TRU, but the increase is not significant. 


\subsection{REFERENCES}

53 Federal Register (FR) 12449, Record of Decision, Final Environmental Impact Statement: Disposal of Hanford Defense High-Level, Transuranic and Tank Wastes, Hanford Site, Richland, Washington, 1988.

AEC, 1970, Immediate Action Directive 0511-21, U. S. Atomic Energy Commission, Washington, D. C.

Ames, R. R., and R. B. Bendixsen, 1997, Central Waste Complex Interim Operations Safety Requirements, HNF-SD-WM-TSR-005, Revision 0, Waste Management Federal Services of Hanford, Inc., Richland, Washington.

Anderson, B. C., 1989, Characterization Plan for Stored Contact-Handled Transuranic Waste, WHC-EP-0223, Westinghouse Hanford Company, Richland, Washington.

Anderson, B. C., and D. R. Duncan, 1989, Sampling Plan for Retrievably Stored ContactHandled Transuranic Waste at the Hanford Site, WHC-EP-0226, Westinghouse Hanford Company, Richland, Washington.

Anderson, B. C., 1991, Contact-Handled Transuranic Waste Characterization Based on Existing Records, WHC-EP-0225, Revision 1, Westinghouse Hanford Company, Richland, Washington.

Bushore, R. P., 1998a, Solid Waste Burial Grounds Interim Safety Analysis, WHC-SD-WMSARR-028, Revision 3B, Waste Management Federal Services of Hanford, Richland, Washington.

Bushore, R. P., 1998b, Solid Waste Burial Grounds Interim Safety Basis, HNF-SD-WM-002, Revision 3A, Waste Management Federal Services of Hanford, Richland, Washington.

Demiter, J. A., 1988, Glovebox Site Evaluation Study for the Characterization of Retrievably Stored Solid TRU Wastes, WHC-IP-0292, Westinghouse Hanford Company, Richland, Washington.

Demiter, J. A., 1993, Explosion Testing for the Container Venting System, WHC-EP-0686, Westinghouse Hanford Company, Richland, Washington.

Demiter, J. A., 1997, Transuranic Drum Retrieval and Venting/Purging at the Savannah River Site - Trip Report, SESC-97-259, SGN Eurisys Services Corporation, Richland, Washington.

Demiter, J. A., 1998, Transuranic Retrieval and Vent/Purging at the Los Alamos National Laboratory - Trip Report, Cogema-98-879, COGEMA Engineering Corporation, Richland, Washington.

DOE, 1987, Final Environmental Impact Statement: Disposal of Hanford Defense High-Level, Transuranic and Tank Wastes, Hanford Site, Richland, Washington, 5 volumes, DOE/EIS0113, U.S. Department of Energy, Washington, D.C. 
DOE, 1995, Environmental Assessment: Solid Waste Retrieval Complex, Enhanced Radioactive and Mixed Waste Storage Facility, Infrastructure Upgrades, and Central Waste Support Complex, DOE/EA-0981, U.S. Department of Energy, Richland, Washington.

Duncan, D. R., et al., 1993, Characterization of Past and Present Solid Waste Streams from the Plutonium Finishing Plant, WHC-EP-0621, Revision 0, Westinghouse Hanford Company, Richland, Washington.

Duncan, D. R., 1994a, Radioactive Waste Shipments to Hanford Retrievable Storage from Babcock and Wilcox, Leechburg, Pennsylvania, WHC-EP-0719, Revision 0, Westinghouse Hanford Company, Richland, Washington.

Duncan, D. R., 1994b, Radioactive Waste Shipments to Hanford Retrievable Storage from Westinghouse Advanced Reactors and Nuclear Fuels Divisions, Cheswick, Pennsylvania, Pennsylvania, WHC-EP-0718, Revision 0, Westinghouse Hanford Company, Richland, Washington.

Duncan, D. R., 1995, Solid Waste Management History of the Hanford Site, WHC-EP-0845, Revision 0 , Westinghouse Hanford Company, Richland, Washington.

Ecology, EPA, and DOE, 1989, Hanford Federal Facility Agreement and Consent Order, as amended, Washington State Department of Ecology, U. S. Environmental Protection Agency, and U.S. Department of Energy, Olympia, Washington.

FDH, 1998a, Hanford Site Solid Waste Acceptance Criteria, HNF-EP-0063, Revision 5, Fluor Daniel Hanford, Richland, Washington.

FDH, 1998b, Facilities Start-Up Readiness, HNF-PRO-055, Revision 1, Fluor Daniel Hanford, Richland, Washington.

FDH, 1999a, Central Waste Complex Waste Analysis Plan, HNF-1886, Revision 0A, Fluor Daniel Hanford, Richland, Washington.

FDH, 1999b, Waste Receiving and Processing Facility Waste Analysis Plan, HNF-2165, Rev. 0A, Fluor Daniel Hanford, Richland, Washington.

Irwin, R. M., 1997, TRU Relocation Status Report, HNF-SD-WM-RPT-287, Revision 0, Rust Federal Services of Hanford, Inc., Richland, Washington.

Joyce, J. P., and M. R. Harker, 1993, Final Safety Analysis for Contact-Handled Transuranic Drums In-Situ Inspection and Vented Drum Retrieval, WHC-SD-WM-SAR-058, Revision 0, Westinghouse Hanford Company, Richland, Washington.

Ludowise, J. D., 1978, Radiolytic Gas Evolution in Z-9 Soil Drums, RHO-CD-681, Rockwell Hanford Operations, Richland, Washington.

McCormick, 1998, Safety Analysis Report for Packaging (Onsite) Steel Drum, HNF-2209, Revision 0, Waste Management Federal Services, Inc., Northwest Operations, Richland, Washington. 
McDonald, K. M., and D. C. DeRosa, 2000, Unvented Drum Handling Plan, HNF-6920, Revision 0, Fluor Hanford, Richland, Washington.

Meyer, M. F., 1997, Interim Safety Basis Document for Solid Waste Facilities (T Plant), HNFSD-WM-ISB-006, Revision 0, Waste Management Federal Services of Hanford, Richland, Washington.

Morton, R. L., 1982, Inspection of Retrievably Stored Transuranic Waste Containers, SD-WMTRP-002, Rockwell Hanford Operations, Richland, Washington.

Perella, V. F., 1995, Alternative Study, TRU Waste Drum Retrieval, G-ADS-E-00001, Revision 0, Westinghouse Savannah River Company, Aiken, South Carolina.

Pottmeyer, J. A., et al., 1993a, Characterization of Past and Present Waste Streams from the Plutonium-Uranium Extraction (PUREX) Plant, WHC-EP-0646, Revision 0, Westinghouse Hanford Company, Richland, Washington.

Pottmeyer, J. A., et al., 1993b, Characterization of Past and Present Waste Streams from 231-Z, WHC-EP-0659, Revision 0, Westinghouse Hanford Company, Richland, Washington.

Pottmeyer, J. A., et al., 1993c, Characterization of Past and Present Waste Streams from the 325 Radiochemistry Building, WHC-EP-0696, Revision 0, Westinghouse Hanford Company, Richland, Washington.

Sargent, F. D., 1998, Central Waste Complex Interim Safety Basis, HNF-SD-WM-ISB-007, Revision 1-C, Waste Management Federal Services of Hanford, Inc., Richland, Washington.

Stevens, P. F., 1994, Safety Analysis Report for Packaging (Onsite) 85-Gallon Retrieval Drum, SD-TP-SARP-006, Rev. 0A, Westinghouse Hanford Company, Richland, Washington.

Vejvoda, E., et al., 1993, Radioactive Waste Shipments to Hanford Retrievable Storage from the General Electric Vallecitos Nuclear Center, Pleasanton, California, WHC-EP-0672, Revision 0, Westinghouse Hanford Company, Richland, Washington.

Weidert, J. R., 1998, Waste Receiving and Processing Facility Final Safety Analysis Report, HNF-SD-W026-SAR-002, Revision 0H, Waste Management Federal Services of Hanford, Richland, Washington.

WHC, 1994, Criticality Safety Evaluation Report 91-003, Criticality Safety Review for 1978-1990 Burial Ground Placement, WHC-SD-SQA-CSA-20346, Westinghouse Hanford Company, Richland, Washington.

WMH, 1997, Waste Management Hanford Procedures, WMH-200, Revision 0, Section 1.6, Operational Readiness Activities, Waste Management Federal Services of Hanford, Richland, Washington.

WMH, 1998, Building Emergency Plan for the Low-Level Burial Grounds, HNF-IP-0263-BG, Revision 6, Waste Management Federal Services of Hanford, Richland, Washington. 


\section{Appendix A}

Sample Statement of Work and Specification for

Mobile Assay System 


\section{Statement of Work \\ LLW-TRU Segregation Assay \\ CH-TRU Drum Retrieval Project}

July 8, 1999

\subsection{Purpose}

The purpose of this contract is to obtain mobile non-destructive assay (NDA) services that are capable of determining whether drums of suspect transuranic (TRU) waste retrieved from the burial grounds are low-level or TRU waste.

\subsection{Background/Introduction}

A primary element of the TRU waste retrieval project is the performance of NDA at the retrieval site. The purpose of the assay is to determine whether suspect TRU drums retrieved from the Hanford low-level waste burial grounds are low-level or TRU waste. Waste determined to be low-level will be repositioned in the burial grounds for permanent emplacement. Waste determined to be TRU will be removed from the burial grounds and placed in storage. The assay must be performed in or near the trench from which the waste is retrieved; thus, the assay equipment must be readily movable. During August 1999, about 200 drums of waste will be retrieved from 218-W-4C, Trench 1, Trench 20 , or Trench 29 . The assay service shall provide "on the spot" raw assay results to facilitate segregation of TRU from LLW, and shall provide a final data package to be used for final decisions on waste disposition.

The assay system will be operated outside in a remote desert environment without utility services. The temperature over the contract period can be expected to vary between 50 and 110 degrees Fahrenheit. Winds and dusty conditions can affect production capability.

The Contractor shall supply these services from contract award, through August 31 , 1999.

\subsection{Scope: Work Tasks, Description and Requirements}

1. The Contractor shall provide a mobile assay system that will be located in or near the burial trenches.

2. The system provided by the Contractor shall be capable of performing nondestructive assay to determine the radionuclide content of 55-gallon drums of waste weighing a maximum of 1,000 pounds. Information about the waste drums to be assayed is provided in Appendix 1 of this SOW including: drum weight, waste physical description, generating facility and radionuclide content data. The Buyer 
will provide the radionuclides of concern to the Contractor for each drum prior to assay.

3. The assay system must possess the sensitivity adequate for the Buyer to determine whether the waste is low-level or TRU using Contractor-supplied assay results. The waste is low-level if it contains TRU radionuclides as defined per Hanford Site Solid Waste Acceptance Criteria, HNF-EP-0063 (can be found at http://www.hanford.gov/wastemgt/wac/criteria.htm) at levels less than or equal to 100 nanocuries per gram waste. The waste is TRU if greater than 100 nanocuries per gram TRU radionuclides exist in a drum. The determination that the waste is lowlevel shall be made with at least an $85 \%$ confidence, that is the assay value plus the uncertainty necessary to provide $85 \%$ confidence for a one-sided distribution, shall be 100 nanocuries per gram or less of TRU constituents. The waste container shall be counted sufficiently long enough to produce an overall uncertainty of less than $20 \%$ at the one-sided $85 \%$ confidence interval.

4. The Contractor shall provide personnel to operate the assay system, and is responsible to maintaining and servicing the equipment. Drum handling activities, including placing and removing drums from the assay system will be done by the Buyer.

5. The Contractor shall provide assay services for assay of up to 200 suspect-TRU drums, averaging at least 10 drums per day, plus necessary QA/QC checks.

6. The Buyer will deliver drums to and receive drums from the assay unit and provide radiation control support to the Contractor.

7. The Contractor shall provide utilities to the assay system including electrical power.

8. Buyer will provide rest room facilities and drinking water to Contractor personnel.

9. The Contractor shall determine and report the weight of each drum with at least $95 \%$ accuracy.

10. The Contractor shall maintain source control at less than $\mathrm{K}_{\mathrm{eff}}$ of 0.95 .

11. The Contractor shall comply with Hanford Site Radiation Control Manual HSRCM-1, latest revision.

12. The assay service shall provide "on the spot" raw assay results for the purpose of distinguishing between waste that is low-level and that which is TRU (or suspect TRU).

13. The Contractor shall provide the following support and assays:

- Every tenth container shall be reassayed to serve as a duplicate for this effort. The duplicate shall have a separate run number and the letter " $\mathrm{D}$ " shall be associated with the container identification number to differentiate it from the original count. Any differences in the results for duplicate assays that do not agree at a two-sided $95 \%$ confidence interval shall be evaluated and resolved in the final reports.

- An empty count of the assay system may need to be done depending upon the Health Physics survey data of the exterior of the waste container. Care must be taken to assure that cross contamination does not occur and that neutron absorbers 
or other light nuclides are present in the waste container will not invalidate the measurement.

- The predominant high-energy photon emitters of interest shall be reported. Results that are less than the method detection limit (MDL) shall be reported for the nuclides of interest.

14. The Contractor shall demonstrate that the following minimum accuracy and precision items are addressed through the Contractor's procedures. The Contractor shall perform this demonstration in the presence of Buyer representatives upon arrival at the work site and prior to the start of drum assay work. The approach provided below is oriented to a Gamma Energy Analysis (GEA) system for developing calibration charts and performing calibration checks. Passive neutron system calibration and calibration checks shall comply with the method provided below but may be performed for an entire drum rather than sections of a drum.

- Establish the system calibration charts. Initially, a minimum of five determinations for each section of the standard container shall be done to establish the control chart.

- Perform system calibration checks:

- Before and after the assay of a day's batch of containers, the same standard shall be used to perform an energy and efficiency calibration check. Each section of the standard container assay shall be evaluated against its control chart to assure that the assay is functioning properly.

- The control charts shall have two and three sigma error bars to determine the performance of the assay system. Depending upon the calibration check results, a conformance or nonconformance determination must be made for the assay system. A nonconforming result shall require resolution by the Contractor up to and including reassay of the drums from the point at which the calibration check last produced a conforming result. Given below is the decision rule to be employed to determine conformance and nonconformance:

- If a control check is within the two-sigma error bars of the control chart, the system is functioning properly.

- For sectioned drum, if one of the control checks is between the two and three sigma error bars and the other control checks are within the twosigma error bars of the control chart, the system is functioning properly.

- For sectioned drum, if two of the control checks are between the two and three sigma error bars of the control chart, a nonconformance report must be written and resolved with the Buyer Technical Representative (BTR) before proceeding with any further work.

- If any of the control checks are outside of the three-sigma error bars of the control chart, a nonconformance report must be written and resolved with the BTR. 
The characterization methods used shall be in accordance with NUREG/CR-5550, Passive Nondestructive Assay of Nuclear Materials; and NUREG 1575, Multi-Agency Radiation Survey and Site Investigation Manual.

\subsection{Deliverables}

The Contractor shall supply the following deliverables:

- Provide a safety plan, as described in the On-Site Services Provisions, for review and approval, within 5 working days from contract award.

- Weekly written reports to the BTR that identify number of units assayed, and any issues associated with the assays.

- A written report for each waste container upon completion of a count sequence that provides sufficient data and documentation to perform the decision process as outlined in Item 3 of Section 3.0 of this SOW. The original shall be provided to the buyer. The brief report shall be in a hard copy format with the following minimum information:

- The container identification number.

- The assay date.

- The total TRU radionuclides content in nanocuries per gram result and container weight in kilograms.

- The uncertainty at the $85 \%$ confidence interval as a nanocuries per gram result.

- The Contractor's comment regarding any noncompliance issue and other comments. If no noncompliance issues exist, the Contractor shall, at a minimum, make a comment such as "no compliance issues exist with this container's TRU assay".

- The Contractor shall sign and date the report. The Contractor personnel's name shall be printed or typed below their signature.

- A space for a brief Buyer comment regarding the disposition of the waste container and any other comments.

- A space for the Buyer's signature and date. The Buyer's name should also be printed below their signature.

- A final written assay report shall be provided for each container within two weeks of the assay of that container. The report may be on an individual container basis, or may group containers together. The Contractor shall use their stationery that shows the company name, address, and phone number. The final report shall have, at a minimum, the following information:

- Date of the report and report number. 
- Title.

- A brief description of the containers assayed for that report. The container identification number for each container shall be used in this section.

- An introduction to the data and where it can be found in the report.

- A discussion of the data and any qualifiers.

- A discussion of any noncompliance issues. If no noncompliance issues exist, a statement shall be made, such as "no noncompliance issues exist with this container's TRU assay".

- A section to provide conclusions and recommendations.

- The Contractor shall sign and date the report. The Contractor personnel's name shall be printed or typed below their signature.

- The data sheet computer printouts shall be attached to the report. The minimum data that shall be reported is each nuclide/analysis with its result, method detection limit and associated uncertainties. The results shall be reported in nanocuries per gram for TRU radionuclides, in an activity per gram value for other radionuclides. The associated uncertainties calculated at the one-sided $85 \%$ confidence interval for TRU radionuclides, and calculated at the two-sided $85 \%$ confidence interval for other radionuclide. The results reported shall include all identified radionuclides of concern and all others that have been detected. The container weight shall be reported in kilograms.

- The MDLs for all radionuclides of concern and all others detected shall be reported at the $85 \%$ confidence interval for their respective type of distributions. A fissile result in grams, using only the available data, shall be generated for each container and reported with the result computer printout.

- The Contractor shall provide the Buyer signed copies of all the associated calibration and system check.

\subsection{Training and Whole Body Count}

Personnel performing work at the Buyer's facility under this task order shall meet the following minimum training: Hanford General Employee Training (HGET), Radiation Worker II, and burial ground facility orientation. Personnel performing work at the Buyer's facility under this task order shall also receive a whole body count.

The requirements stated herein shall apply to all lower tier subcontractors.

\subsection{Quality Assurance}

The contractor shall maintain and implement a Quality Assurance program in compliance with the following ASME NQA-1 (latest edition) requirements:

$$
\text { Requirement } 1 \quad \text { Organization }
$$




\begin{tabular}{|c|c|}
\hline Requirement 2 & Quality Assurance Program \\
\hline Requirement 3 & Design Control \\
\hline Requirement 5 & Instructions, Procedures and Drawings \\
\hline Requirement 6 & Document Control \\
\hline Requirement 10 & Inspection \\
\hline Requirement 12 & Control of Measuring and Test Equipmen \\
\hline Requirement 14 & Inspection, Test, and Operating Status \\
\hline Requirement 15 & Control of Nonconforming Items \\
\hline Requirement 16 & Corrective Action \\
\hline Requirement 17 & Quality Assurance Records \\
\hline
\end{tabular}

The Contractor is subject to Title 10, Code of Federal Regulations, Part 830.120 (10 CFR830.120), Quality Assurance Requirements, and the enforcement actions under 10 CFR 820, General Statement of Enforcement Policy. The applicable requirements of 10 CFR 830.120 shall be passed down to all subcontractors performing to this SOW.

\subsection{Environmental, Safety and Health (ES\&H)}

The Contractor shall comply with all ES\&H requirements contained in the On-Site Services Provisions when operating at the Buyer's facility. The Buyer and the Contractor shall both have the authority and the responsibility to "stop work" whenever a safety concern is identified.

\subsection{Insurance}

The Contractor shall maintain liability insurance in accordance with the On-Site Service Provisions of this contract. The Contractor shall be responsible for any additional property and liability insurance required for the transportation of the Contractor's equipment on or off the Hanford Site. The Buyer shall not be liable for damage to the Contractor's property or any other liability associated with the transportation of the Contractor's equipment.

\subsection{Buyer Support}

The Buyer will provide all of the required support operators, health physics personnel, craft personnel, and other personnel required for the movement of waste containers in support of the Contractors performance of NDA. 


\subsection{Schedule to Perform Work}

The Contractor shall Provide Safety Plan, accomplish Training Requirements, and mobilize equipment within 5 working days from the award of contract.

The Contractor shall supply assay services on the Hanford Site from August 2, 1999, through August 31, 1999.

Demobilization and removal of Contractor equipment shall be completed within five working days after assay of the final drum.

The Contractors shall submit final assay reports within two weeks of the last assay.

The Contractor shall perform work at the Buyer's site during normal buyer's work days and work hours. For this contract the work days are Monday through Friday, August 2, 1999 through August 31, 1999, with the exception of Friday August 6 and Friday August 20 which are non-working days. Work hours are from 7:00 a.m. to 4:30 p.m. with 1/2 hour lunch at 11:30 a.m.

\subsection{Buyer's Technical Representatives}

Kent McDonald, (509) 373-4981

Dave DeRosa, (509) 376-7900 
HNF-4781, Revision 1

\section{Appendix B}

NEPA Screening Form

B-1 


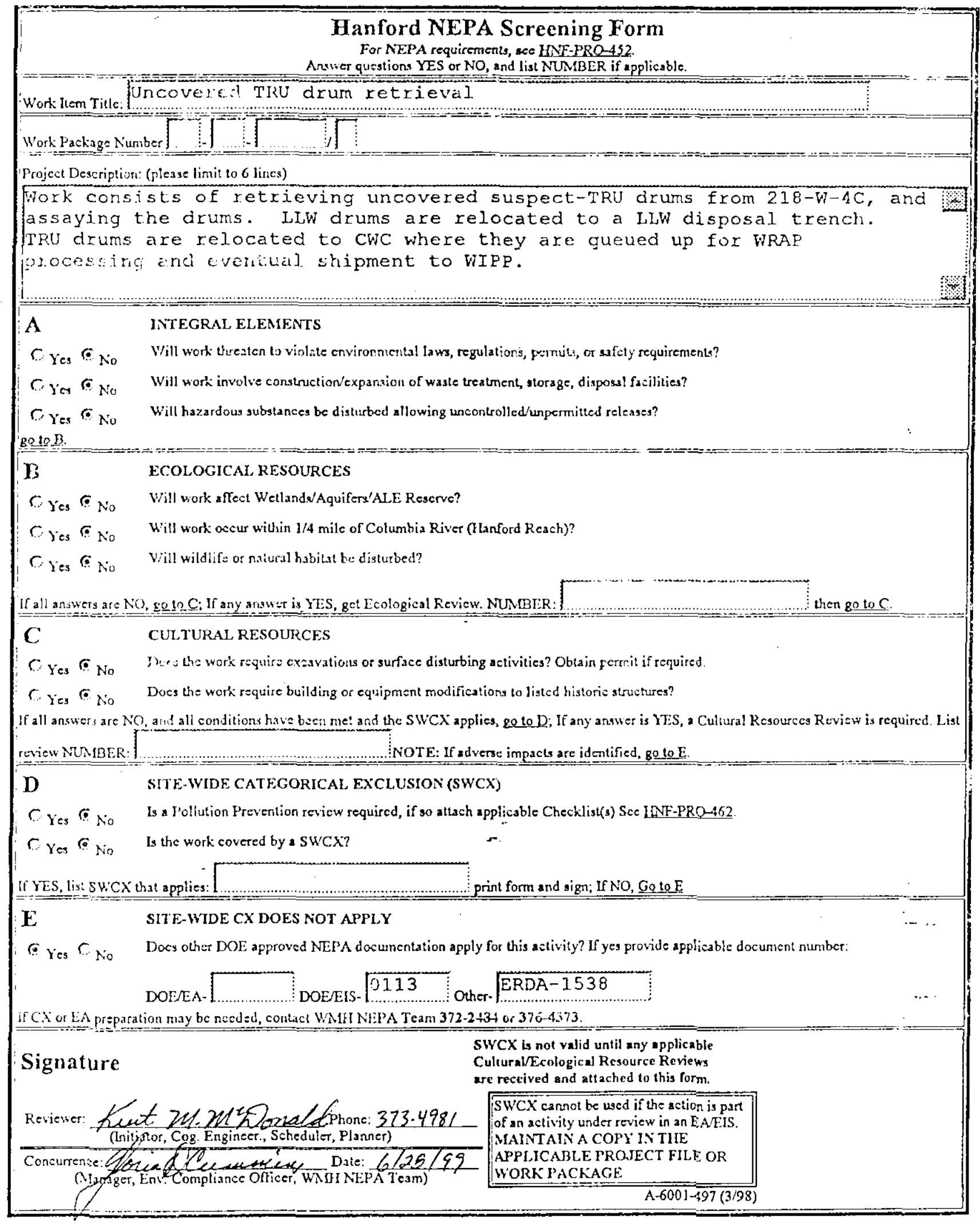

\section{Hanford Home Page | WMH Home Page}

\section{$B-2$}




\section{Appendix C}

DRAFT Strategy for Preparation of A Notice of Construction for Operation of The Container Venting System 
NOC Strategy Worksheet

\section{Phase I Transuranic (TRU) Retrieval from the LLBG}

\section{a) Basic, brief project description:}

From 1970 to 1988 , management of TRU and suspect-TRU waste containers consisted of placement of these containers in the Low Level Burial Grounds (LLBG). A DOE-RL programmatic decision has been made to retrieve the TRU waste containers for eventual transfer to the Waste Isolation Pilot Project (WIPP). Trenches 1, 20, and 29 of LLBG 218-W-4C include 1530 containers that are prime candidates for Phase I TRU retrieval. These containers have not been covered with soil, hence no excavation would be necessary during retrieval (see attached photograph).

Containers of TRU waste are required to be vented as a safety measure to prevent the buildup of hydrogen gas and as part of the certification process to meet WIPP waste analysis criteria. It is estimated that a small percentage (less than 1\%) of the TRU containers to be retrieved are not vented. Drums that are not vented will be subjected to the Container Venting System (CVS), which includes drilling a hole in the container lid with a spark resistant titanium nitride drill bit, extracting gases, and backcharging the drum with inert gas. A NucFil ${ }^{\circledR}$ filter, or equivalent, will then be installed by hand. While attached to the drum, the CVS is sealed to the drum such that any emissions are released through the HEPA-filtered exhaust for the CVS. See the attached photograph for a perspective of the CVS.

The purpose of this NOC is to obtain prior approval for venting the non-vented containers that are retrieved during the Phase I TRU retrieval process. Venting of containers will take place at the LLBG.

\section{b) Annual possession quantity (APQ)}

The SWITS database was queried regarding the radionuclides present in the 1530 drums that are candidates for Phase I TRU retrieval. All plutonium isotopes were combined and represented as Pu-239. Americium-241 was conservatively selected as being representative of all alpha emitters and $\mathrm{Sr}-90$ was conservatively selected to represent all beta/gamma emitters. The SWITS database was further queried for the individual drums with the maximum curie inventory of plutonium, alpha emitters, and beta/gamma emitters. It was conservatively assumed that these maximum inventories are located in a single drum ("maximum drum"). For added conservatism, it was assumed that a total of 60 drums (approximately $4 \%$ of the total number of drums) would be vented by the CVS. The inventory of the maximum drum was multiplied by 60 drums to determine a total APQ. See attached spreadsheet. 


\section{c) Approach for determining the potential-to-emit (PTE)}

As a condition of the NOC for $\mathrm{CWC}, \mathrm{NucFil}^{\circledR}$ filters are to be analyzed to determine radionuclide retention on the filters. In concert with the radionuclide inventory of the container associated with a particular filter, a release fraction will be calculated for a vented non-filtered container. This release fraction will be applied to the APQ to determine the potential-to-emit.

\section{d) Abatement technology (BARCT or ALARACT and/or T-BACT)}

ALARACT is the abatement technology and will consist of HEPA filtration for the CVS exhaust and administrative controls to minimize, and at worst case limit the time any single drum is open and venting, without filtration, to one hour.

\section{e) Appropriate monitoring and sampling, including periodic confirmatory measurements, if applicable}

Due to the CVS configuration it is very difficult to sample the CVS exhaust. Emissions from vented drums are considered to be fugitive. The ongoing near-field air monitoring program for the Hanford Site will be used to confirm low emissions. Ambient air monitors N-449, N-457, N964 , and $\mathrm{N}-433$ will be maintained for the duration of this project as monitors of diffuse and fugitive emissions. In addition, swipe samples will be obtained on the drum lids on the area surrounding the vent point after installation of the NucFil ${ }^{\circledR}$ filters to verify low emissions.

\section{(f) Rationale for NOC application style and schedule needs}

The NOC application will be a short form due to the low unabated PTE. Based on preliminary results of the CWC NucFil ${ }^{8}$ filter study, it is anticipated that the total unabated dose will be very low. Regarding schedule needs, Phase I TRU retrieval is scheduled to begin by September 30 , 1999.

\section{Signatures:}

Concurrence that the above description is an acceptable path forward for NOC application development.

Eric M. Greager, Manager WMH Air \& Water Services

\section{Date}

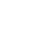

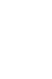

\author{
John Bates, FDH
}

Date 


\title{
Appendix D
}

\section{Cost Estimating Worksheet for Phase I Retrieval}

\author{
Consisting of: \\ Pre-Retrieval Activities \\ Records Reviews \\ Uncovered Retrieval Campaigns \\ Covered Retrieval Campaigns \\ Summary
}




\section{Pre-Retrieval Activities}

Task/Assumptions Resource Number Multiplier Units Total Hrs Org Unit Cost Total Cost

Waste Management Plan Draft Waste Management Plan Tech Plan $\mathrm{MacTec}$ Tech Ops ECO

Gen Svcs

$20 \mathrm{hrs}$ $300 \mathrm{hrs}$ $20 \mathrm{hrs}$ $20 \mathrm{hrs}$

$40 \mathrm{hrs}$

Respond to DOE/FDH Comments Tech Plan

MacTec

Tech Ops

ECO

Gen Svcs

Ecology Comment Resolution/Approval

Tech Plan
MacTec
Tech Ops
ECO
Gen Svcs

Subtotal WAP

Procure Mobile Assay System

Develop Data Quality Objectives for Mobile Assay

Tech Plan
Gen Svcs
QA
PO Contract

$20 \mathrm{hrs}$

$80 \mathrm{hrs}$

$10 \mathrm{hrs}$

$10 \mathrm{hrs}$

$10 \mathrm{hrs}$

$20 \mathrm{hrs}$

$100 \mathrm{hrs}$

$20 \mathrm{hrs}$

$20 \mathrm{hrs}$

20 hrs

$20 \mathrm{hrs}$

$100 \mathrm{hrs}$
$2032 \mathrm{KOO}$

$300 \mathrm{MacTec}$

$20 \quad 32 \mathrm{~B} 00$

$40 \quad 32 A 00$

$40 \quad 33200$

$20 \quad 32 \mathrm{KOO}$

$80 \mathrm{MacTec}$

$10 \quad 32 \mathrm{~B} 00$

$10 \quad 32 A 00$

$10 \quad 33200$

$20 \quad 32 \mathrm{KOO}$

$100 \mathrm{MacTec}$

$20 \quad 32800$

$20 \quad 32 \mathrm{AOO}$

$20 \quad 33200$
$\$ 65.09$

$\$ 53.28 \quad \$ 1,066$

$\$ 60.54 \quad \$ 2,422$

$\$ 55.06 \quad \$ 2,202$

$\$ 65.09$

$\$ 80.00$

$\$ 53.28$

$\$ 60.54$

$\$ 55.06$

$\$ 65.09$

$\$ 80.00$

$\$ 53.28$

$\$ 60.54$

$\$ 55.06$
$\$ 1,302$

$\$ 8,000$

$\$ 1,066$

$\$ 1,211$

$\$ 1,101$

$\$ 53,061$ $\begin{array}{ll}20 & 32 K 00 \\ 20 & 33200\end{array}$

20
100

Write Spec for Mobile Assay System

Tech Pian

Tech Ops

COGEMA

QA

Buyer

Issue RFP for Mobile Assay System

Tech Plan

Buyer

80 hrs

$80 \mathrm{hrs}$

$80 \mathrm{hrs}$

$20 \mathrm{hrs}$

$20 \mathrm{hrs}$

$10 \mathrm{hrs}$

$40 \mathrm{hrs}$

$40 \mathrm{hrs}$

$40 \mathrm{hrs}$

40 hrs

$\begin{array}{ll}\$ 65.09 & \$ 1,302 \\ \$ 55.06 & \$ 1,101 \\ \$ 60.79 & \$ 1,216 \\ \$ 90.00 & \$ 9,000\end{array}$

$\$ 65.09$

$\$ 53.28$

$\$ 80.00$

$\$ 60.79$

$\$ 42.54$

$\$ 65.09$

$40 \quad 30000 \quad \$ 42.54 \quad \$ 1,702$

$\$ 651$

Award Bid for Mobile Assay Lease

Tech Plan

QA

Buyer

$40 \quad 32 K 00$

$40 \quad 31500$

4030000

$\$ 65.09$

$\$ 60.79$

$\$ 42.54$

$\$ 2,604$

$\$ 2,432$

$\$ 1,702$

Mobile Assay Selup/Operation/Demobilization See individual campaigns on retrieval tabs.

Mobile Assay Procurement Subtotal

$\$ 39,644$

Container Venting System

CVS Assess Operability

COGEMA
$40 \mathrm{hrs}$

$20 \mathrm{hrs}$
$40 \quad 08000$

$20 \quad 32 \mathrm{KOO}$
$\$ 80.00$

$\$ 65.09$
$\$ 3,200$

$\$ 1,302$ 


\section{Pre-Retrieval Activities}

\section{Task/Assumptions Resource
Tech Ops Engineering Maintenance Materials NPO}

CVS Write Procedures

Engineering
QA
Nuclear Safety
1st line spvsr
Indust. Hygiene
Health Physicist
Proc. Writer
Tech Ops
NPO

CVS Training

Engineer
Trainer
NPO
NPO
Indust. Hygiene
RCT

Subtotal Container Venting System

Air Permitting

Write NOC for CVS

$$
\begin{aligned}
& \text { Env. Svcs } \\
& \text { Eco } \\
& \text { Tech Plan } \\
& \text { Tech Ops }
\end{aligned}
$$

Subtotal NOC for CVS

Write NOC for Excavation Retrieval Draft NOC

$$
\begin{aligned}
& \text { Env. Sves } \\
& \text { ECO } \\
& \text { Tech Plan }
\end{aligned}
$$$$
\text { Tech Ops }
$$

DOE/FDH Approval/Comments

$$
\begin{aligned}
& \text { Env. Svcs } \\
& \text { Eco } \\
& \text { Tech Plan } \\
& \text { Tech Ops }
\end{aligned}
$$

DOH/EPA Negotiations

$$
\begin{aligned}
& \text { Env. Svcs } \\
& \text { ECO } \\
& \text { Tech Plan } \\
& \text { Tech Ops }
\end{aligned}
$$

Subtotal NOC for Excavation

Subtotal Air Permitting

$\begin{array}{cc}\text { Number Multiplier Units } \\ 1 & 40 \mathrm{hrs} \\ 1 & 40 \mathrm{hrs} \\ 1 & 40 \mathrm{hrs} \\ 1 & 5000 \mathrm{\$} \\ 3 & 40 \mathrm{hrs}\end{array}$

Total H

Unit Cost Total Cost

\section{$\$ 53.28$}

$\$ 64.58$

$\$ 49.28$

1.20

$12063 A 00$

$\$ 53.99$

$\$ 2,131$

$\$ 2,583$

$\$ 1,971$

$\$ 6,000$

$\$ 6,479$

$40 \mathrm{hrs}$
$8 \mathrm{hrs}$
$8 \mathrm{hrs}$
$8 \mathrm{hrs}$
$8 \mathrm{hrs}$
$8 \mathrm{hrs}$
$40 \mathrm{hrs}$
$20 \mathrm{hrs}$
$20 \mathrm{hrs}$

$40 \mathrm{hrs}$

$80 \mathrm{hrs}$

$40 \mathrm{hrs}$

$4 \mathrm{hrs}$

$4 \mathrm{hrs}$

$4 \mathrm{hrs}$
$\$ 64.58$

$\$ 60.79$

$\$ 65.72$

$\$ 84.67$

$\$ 58.81$

$\$ 57.79$

$\$ 36.21$

$\$ 53.28$

$\$ 53.99$

$\$ 2,583$

$\$ 486$

$\$ 526$

$\$ 677$

$\$ 470$

$\$ 462$

$\$ 1,448$

$\$ 1,066$

$\$ 1,080$

$\$ 53.99$

$\begin{array}{lr}\$ 64.58 & \$ 2,583 \\ \$ 47.68 & \$ 3,814 \\ \$ 53.99 & \$ 2,160 \\ \$ 53.99 & \$ 2,160 \\ \$ 58.81 & \$ 470 \\ \$ 49.56 & \$ 991\end{array}$

$\$ 44,644$
$\$ 55.06$
$\$ 60.54$
$\$ 55.09$
$\$ 53.28$

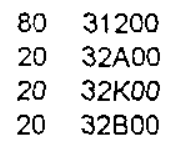

$20 \quad 32 \mathrm{~B} 00$
$\$ 4,405$

$\$ 1,211$

$\$ 1,302$

$\$ 1,066$

$\$ 7,983$

$\$ 8,810$

$\$ 2,422$

$\$ 2,604$

$\$ 2,131$

$\$ 60.54$

$\$ 65.09$

$\$ 53.28$

$\$ 55.06$

$\$ 60.54$

$\$ 65.09$

$\$ 53.28$

$\$ 4,405$

$20 \mathrm{hrs}$

$20 \mathrm{hrs}$

20 hrs

$80 \mathrm{hrs}$
$20 \mathrm{hrs}$
$20 \mathrm{hrs}$
$20 \mathrm{hrs}$

$\$ 55.06$

$\$ 60.54$

$\$ 65.09$

$\$ 53.28$
$\$ 1,211$

$\$ 1,302 \ldots$

$\$ 1,066$

$\$ 4,405$

$\$ 1,211$

$\$ 1,302$

$\$ 1,066$

$\$ 31,932$

$\$ 39,915$ 


\section{Pre-Retrieval Activities}

Task/Assumptions Resource Number Multiplier Units Total Hrs Org Unit Cost Total Cost Safety Basis Modifications

ISB Mods for CVS/Mobile Assay (LLBG) Draft Mods

Engineer
Nuc Safely
PO Contract

80 hrs

$40 \mathrm{hrs}$

$\begin{array}{ll}80 & 32800 \\ 40 & 31400\end{array}$

$\$ 64.58$

$\$ 2,629$

PO Contract

$\$ 100.00 \$ / h r$

$240 \quad 08000$

Internal Reviews
Engineer

RCT

1st line spvsr

Env. Svcs

ECO

Tech Plan

Tech Ops

Nuc Safety

Gen Svcs

QA

Health Physicist

Indust. Hygiene

DOE/FDH Approval/Comments

$\begin{array}{llr}\text { Engineer } & 1 & 80 \mathrm{hrs} \\ \text { Nuc Safety } & 1 & 40 \mathrm{hrs} \\ \text { PO Contract } & 1 & \$ 10000 \mathrm{~s} / \mathrm{hr}\end{array}$

PO Contract
24 hrs

$8 \mathrm{hrs}$

8 hrs

8 hrs

$8 \mathrm{hrs}$

$8 \mathrm{hrs}$

$8 \mathrm{hrs}$

$8 \mathrm{hrs}$

$8 \mathrm{hrs}$

$8 \mathrm{hrs}$

8 hrs

8 hrs

8 hrs

$\$ 100.00 \$ / h r$
$24 \quad 32900$

$16 \quad 63 A 00$

$8 \quad 63 A 00$

$832 \mathrm{AOO}$

$8 \quad 31200$

$832 A 00$

$832 \mathrm{KOO}$

$832 \mathrm{BOO}$

831400

833200

831500

$8 \quad 32 A 00$

831300

$\begin{array}{ll}80 & 32900 \\ 40 & 31400\end{array}$

$240 \quad 08000$
$1.2 \$ 28,800$

$\$ 64.58$

$\$ 53.99$

$\$ 49.56$

$\$ 84.67$

$\$ 55.06$

$\$ 60.54$

$\$ 65.09$

$\$ 53.28$

$\$ 65.72$

$\$ 55.06$

$\$ 60.79$

$\$ 57.79$

$\$ 58.81$

$\$ 1,550$

$\$ 864$

$\$ 396$

$\$ 677$

$\$ 440$

$\$ 484$

$\$ 521$

$\$ 426$

$\$ 526$

$\$ 440$

$\$ 486$

$\$ 462$

$\$ 470$

$\$ 64.58$

$\$ 65.72$

$\$ 5,166$

$\$ 2,629$

$\$ 28,800$

Subtotal ISB Mods for CVS/Mobile Assay (LLBG)

ISB Mod's for CWCMRAP Draft Mods

Engineer Nuc Safety

PO Contrac

$80 \mathrm{hrs}$

$\$ 100.00 \$ / h r$

$\begin{array}{ll}80 & 32900 \\ 40 & 31400\end{array}$

$240 \quad 08000$

$\$ 64.58$

$\$ 65.72$

$\$ 5,166$

1.2

$\$ 2,629$

$\$ 28,800$

Internal Reviews

Engineer

NPO

RCT

1 st line spvsr

Env. Svcs

ECO

Tech Plan

Tech Ops

Nuc Safety

Gen Sves

QA

Health Physicist

Indust. Hygiene

$24 \mathrm{hrs}$

$8 \mathrm{hrs}$

$8 \mathrm{hrs}$

$8 \mathrm{hrs}$

8 hrs

$8 \mathrm{hrs}$

$8 \mathrm{hrs}$

$8 \mathrm{hrs}$

8 hrs

$8 \mathrm{hrs}$

$8 \mathrm{hrs}$

$8 \mathrm{hrs}$

$8 \mathrm{hrs}$

$$
\begin{array}{rl}
24 & 32900 \\
8 & 63 A 00 \\
8 & 63 A 00 \\
8 & 32 A 00 \\
8 & 31200 \\
8 & 32 A 00 \\
8 & 32 K 00 \\
8 & 32 B 00 \\
8 & 31400 \\
8 & 33200 \\
8 & 31500 \\
8 & 32 A 00 \\
8 & 31300
\end{array}
$$

$\$ 64.58$

$\$ 53.99$

$\$ 49.56$

$\$ 84.67$

$\$ 55.06$

$\$ 60.54$

$\$ 65.09$

$\$ 53.28$

$\$ 65.72$

$\$ 55.06$

$\$ 60.79$

$\$ 57.79$

$\$ 58.81$

$\$ 1,550$

$\$ 432$

$\$ 396$

$\$ 677$

$\$ 440$

$\$ 484$

$\$ 521$

$\$ 426$

$\$ 526$

$\$ 440$

$\$ 486$

$\$ 462 \ldots$

$\$ 470$

DOE/FDH Approval/Comments

$\begin{array}{llr}\text { Engineer } & 1 & 80 \mathrm{hrs} \\ \text { Nuc Safety } & 1 & 40 \mathrm{hrs} \\ \text { PO Contract } & 1 & \$ 10000 \mathrm{~s} / \mathrm{hr}\end{array}$

$\begin{array}{rr}80 & 32900 \\ 40 & 31400 \\ 240 & 08000\end{array}$

$\$ 64.58$
$\$ 65.72$

$\$ 5,166$

$\$ 2,629$

$\$ 28,800$

$\$ 80,503$

Subtotal ISB Mods for CWCMRAP

CSER/CPS ModS

Draft Mods

Engineer

Nuc Safety

PO Contract

$\begin{array}{lr}1 & 80 \mathrm{hrs} \\ 1 & 40 \mathrm{hrs} \\ 1 & \$ 100.00 \$ / \mathrm{hr}\end{array}$

$80 \quad 32900$

$\$ 64.58$

$\$ 5,166$

$40 \quad 31400$

$240 \quad 08000$
$\$ 2,629$

$\$ 28,800$ 


\section{Pre-Retrieval Activities}

Task/Assumptions Resource Number Multiplier Units Total Hrs Org Unit Cost Total Cost

DOE/FDH Approval/Comments

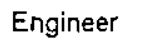

PO Contract $\begin{array}{lr}1 & 80 \mathrm{hrs} \\ 1 & \$ 100.00 \$ / / \mathrm{rr}\end{array}$ $\begin{array}{rr}80 & 32900 \\ 240 & 08000\end{array}$

$\$ 64.58$

$\$ 5,166$

$\$ 28,800$

$\$ 70,562$

Design Retrieval Process (covered drums)

Draft Design

Engineer
Tech Planning
PO Contract

DOE/FDH Approval/Comments

Engineer
PO Contract

$\begin{array}{lr}1 & 80 \mathrm{hrs} \\ 1 & 80 \mathrm{hrs} \\ 1 & \$ 100.00 \$ / \mathrm{hr}\end{array}$

$\begin{array}{cr}1 & 80 \mathrm{hrs} \\ 1 & \$ 100.00 \$ / \mathrm{hr}\end{array}$

Subtotal Design Retrieval Process

MSAR Modifications for Retrieval Draft Mods

Engineer
Nuc Safety
PO Contract

Internal Reviews

Engineer
NPO
RCT
1st line spvs

Env. Sves

ECO

Tech Plan

Tech Ops

Nuc Safety

Gen Svcs

QA

Health Physicist

Indust. Hygiene

DOE/FDH Approval/Comments

$$
\begin{aligned}
& \text { Engineer } \\
& \text { Nuc Safety } \\
& \text { PO Contract }
\end{aligned}
$$

Subtotal MSAR Modifications for Excavation

Subtotal Safety Basis Modifications
240

$720 \quad 08000$

72

24

24

24

24

24

$32 \mathrm{AOO}$

$2432 \mathrm{KOO}$

$24 \quad 32800$

2431400

$24 \quad 33200$

$24 \quad 31500$

$2432 \mathrm{A00}$

$24 \quad 31300$

$240 \quad 32900$

$120 \quad 31400$

$720 \quad 08000$
$120 \quad 31400$

$\begin{array}{rr}\$ 64.58 & \$ 15,499 \\ \$ 65.72 & \$ 7,886 \\ 1.2 & \$ 86,400\end{array}$

$\$ 64.58 \quad \$ 4,650$

$\$ 53.99 \quad \$ 1,296$

$\$ 49.56 \quad \$ 1,189$

$\$ 84.67 \quad \$ 2,032$

$\$ 55.06 \quad \$ 1,321$

$\$ 60.54 \quad \$ 1,453$

$\$ 65.09 \quad \$ 1,562$

$\$ 53.28 \quad \$ 1,279$

$\$ 65.72 \quad \$ 1,577$

$\$ 55.06 \quad \$ 1,321$

$\$ 60.79 \quad \$ 1,459$

$\$ 57.79 \quad \$ 1,387$

$\begin{array}{rr}\$ 64.58 & \$ 15,499 \\ \$ 65.72 & \$ 7,886 \\ 1.2 & \$ 86,400\end{array}$

$\$ 241,510$

$\$ 546,650 \ldots$
$\$ 58.81 \quad \$ 1,411$

SARP Modifications

Evaluate SARP Modifications

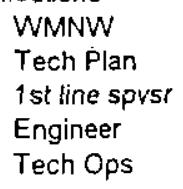

$100 \mathrm{hrs}$

$10 \mathrm{hrs}$

$10 \mathrm{hrs}$

$10 \mathrm{hrs}$

$10 \mathrm{hrs}$

$100 \quad 08000$

$\$ 80.00$

$\$ 65.09$

$\$ 84.67$

$\$ 64.58$

$10 \quad 32 A 00$

$10 \quad 32900$

$\begin{array}{llll}10 & 32900 & \$ 64.58 & \$ 646 \\ 10 & 32 \mathrm{~B} 00 & \$ 53.28 & \$ 533\end{array}$

$\$ 8,000$

$\$ 651$

$\$ 847$

$\$ 646$

MOdify SARPS

WMNW
Tech Plan
1s! line spysr

$300 \mathrm{hrs}$

$300 \quad 08000$

$\$ 80.00$

$\$ 65.09$

$\$ 24,000$

$20 \mathrm{hrs}$

$20 \quad 32 \mathrm{KOO}$

$\$ 84.67$

$\$ 1,302$

$\$ 1,693$ 


\section{Pre-Retrieval Activities}

Task/Assumptions

\begin{abstract}
Resource
Tech Ops

Engineer
\end{abstract}

Number Multiplier Units

$40 \mathrm{hrs}$
Total Hrs

$\begin{array}{ll}20 & 32800 \\ 40 & 32900\end{array}$
Unit Cost Total Cost

$\$ 53.28$

$\$ 64.58$

$\$ 1,066$

$\$ 2,583$

$\$ 41,320$

Subtotal SARP Modifications

NEPA

Evaluate NEPA Dacumentation

Env. Svcs
ECO
Tech Plan

$\begin{array}{ll}1 & 80 \mathrm{hrs} \\ 1 & 20 \mathrm{hrs} \\ 1 & 20 \mathrm{hrs}\end{array}$

$80 \mathrm{hrs}$
$20 \mathrm{hrs}$

$20 \mathrm{hrs}$

$\begin{array}{ll}80 & 31200 \\ 20 & 32 A 00\end{array}$

$20 \quad 32 \mathrm{KOO}$

$\$ 55.06$

$\$ 60.54$

$\$ 65.09$

$\$ 4,405$

$\$ 1,211$

$\$ 1,302$

$\$ 6,917$

Health Physic

NPO

Subtotal Procedures (uncovered retrieval)

Review/Rewrite Procedures (excavation retrieval)

Number of procedure revisions

Engineer

Proc. Writer

1st line spvsr

QA

Nuc Safely

Indust. Hygiene

Tech Ops

Health Physic

NPO

Subtotal Procedures (uncovered retrieval)

Subtotal Procedure Revisions

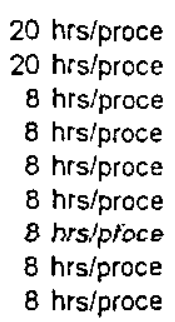

$8 \mathrm{hrs} / \mathrm{proce}$

$\begin{array}{ll}320 & 32900 \\ 320 & 31400 \\ 128 & 32 A 00 \\ 128 & 31500 \\ 128 & 31400 \\ 128 & 31300 \\ 128 & 32 B 00 \\ 128 & 32 A 00 \\ 128 & 63 A 00\end{array}$

$32 \mathrm{~B} 00$

$32 \mathrm{~A} 00$

$63 A 00$
$\$ 64.58$

$\$ 36.21$

$\$ 84.67$

$\$ 60.79$

$\$ 65.72$

$\$ 58.81$

$\$ 53.28$

$\$ 57.79$

$\$ 53.99$
$\$ 5,166$

$\$ 2,897$

$\$ 2,709$

$\$ 1,945$

$\$ 2,103$

$\$ 1,882$

$\$ 1,705$

$\$ 1,849$

$\$ 1,728$

$\$ 27,985$

$\begin{array}{ll}\$ 64.58 & \$ 20,666 \\ \$ 36.21 & \$ 11,587 \\ \$ 84.67 & \$ 10,838 \\ \$ 60.79 & \$ 7,781 \\ \$ 65.72 & \$ 8,412 \\ \$ 58.81 & \$ 7,528 \\ \$ 53.28 & \$ 6,820 \\ \$ 57.79 & \$ 7,397 \\ \$ 53.99 & \$ 6,911\end{array}$

$\$ 87,939$

$\$ 109,924$

\section{Training}

Training for uncovere d retrieval

See training under CVS.

Training tor excavation retrieval

Engineer
Trainer
Tech Ops
Indust. Hygiene
NPO
NPO
RCT

$\begin{array}{rr}1 & 160 \mathrm{hrs} \\ 1 & 480 \mathrm{hrs} \\ 1 & 40 \mathrm{hrs} \\ 1 & 40 \mathrm{hrs} \\ 1 & 40 \mathrm{hrs} \\ 10 & 8 \mathrm{hrs} \\ 5 & 8 \mathrm{hrs}\end{array}$

Subtotal Training

RCT

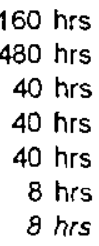

$\begin{array}{rr}160 & 32900 \\ 480 & 32800 \\ 40 & 32 B 00 \\ 40 & 31300 \\ 40 & 63 A 00 \\ 80 & 63 A 00 \\ 40 & 63 A 00\end{array}$
$\$ 64.58$

$\$ 47.68$

$\$ 53.28$

$\$ 58.81$

$\$ 53.99$

$\$ 53.99$

$\$ 49.56$
$\$ 10,333$

$\$ 22,886$

$\$ 2,131$

$\$ 2,352$

$\$ 2,160$

$\$ 4,319$

$\$ 1,982$ 


\section{Pre-Retrieval Activities}

Task/Assumptions Resource Number Multiplier Units Total Hrs Org Unit Cost Total Cost

Prestart Activities

NPO
1st line spvsr
RCT
Materials
1st line spvsr

$\begin{array}{cc}2 & 80 \mathrm{hrs} \\ 1 & 20 \mathrm{hrs} \\ 1 & 80 \mathrm{hrs} \\ 1 & 5000 \mathrm{~S} \\ 1 & 20 \mathrm{hr}\end{array}$

$\begin{array}{rrrr}160 & 63 A 00 & \$ 53.99 & \$ 8,638 \\ 20 & 32 A 00 & \$ 84.67 & \$ 1,693 \\ 80 & 63 A 00 & \$ 49.56 & \$ 3,965 \\ & & 1.20 & \$ 6,000 \\ 20 & 32 A 00 & \$ 84.67 & \$ 1,693\end{array}$

Subtotal Prestart Activities

$20 \mathrm{hr}$

$\$ 21,990$

\section{Operational Readiness Review \\ Prepare readiness checklistaffadavits

Engineer
NPO
RCT
1 st line spvsr
Env. Svcs
ECO
Tech Plan
Tech Ops
QA
Nuc Safety
Gen Svcs
Health Physicist
Indust. Hygiene

Subtotal Readiness Checklist

Readiness team review

WMH Engineer FDH Engineer

Subtotal Readiness Review Team

Grand Total Pre-Retrieval Activities

$160 \mathrm{hrs}$
$160 \mathrm{hrs}$
$160 \mathrm{hrs}$
$160 \mathrm{hr}$
$160 \mathrm{hrs}$
$160 \mathrm{hrs}$
$160 \mathrm{hrs}$
$160 \mathrm{hrs}$
$160 \mathrm{hrs}$
$160 \mathrm{hrs}$
$160 \mathrm{hrs}$
$160 \mathrm{hrs}$
$160 \mathrm{hrs}$

$480 \quad 32900$

$160 \quad 63 A 00$

$160 \quad 63 \mathrm{A00}$

$160 \quad 32 A 00$

$160 \quad 31200$

$160 \quad 32 \mathrm{A00}$

$160 \quad 32 \mathrm{KOO}$

$160 \quad 32800$

$160 \quad 31500$

$160 \quad 31400$

$160 \quad 33200$

$160 \quad 32 \mathrm{AOO}$

$160 \quad 31300$

$\$ 64.58$
$\$ 53.99$
$\$ 49.56$
$\$ 84.67$
$\$ 55.06$
$\$ 60.54$
$\$ 65.09$
$\$ 53.28$
$\$ 60.79$
$\$ 65.72$
$\$ 55.06$
$\$ 57.79$
$\$ 58.81$

$480 \quad 32900$

$360 \quad 32900$

$\begin{array}{ll}8 & 60 \mathrm{hrs} \\ 4 & 90 \mathrm{hrs}\end{array}$

$\begin{array}{ll}8 & 60 \mathrm{hrs} \\ 4 & 90 \mathrm{hrs}\end{array}$
$\$ 30,998$
$\$ 8,638$
$\$ 7,930$
$\$ 13,547$
$\$ 8,810$
$\$ 9,686$
$\$ 10,414$
$\$ 8,525$
$\$ 9,726$
$\$ 10,515$
$\$ 8,810$
$\$ 9,246$
$\$ 9,410$

$\$ 146,256$

$\$ 64.58 \quad \$ 30,998$

$\$ 64.58 \quad \$ 23,249$

$\$ 54,247$

$\$ 1,150,733$ 


\section{Records Reviews}

\section{Task/Assumptions Resource Number Multiplier Units Total Hrs Org Unit Cost Total Cost}

\section{Records Review 1st campaign}

Includes batching, location/accesibility, possible hazards, pick lists

\# of drums in campaign 300

$\begin{array}{lllrll}\text { Gen Svcs } & 1 & 0.5 \mathrm{hr} / \mathrm{drum} & 150 & 33200 & \$ 55.06 \\ \text { SWITS } & 1 & 0.1 \mathrm{hr} / \mathrm{drum} & 30 & 32800 & \$ 55.06 \\ \text { 1st line spvsr } & 1 & 0.1 \mathrm{hr} / \mathrm{drum} & 30 & 32400 & \$ 84.67 \\ \text { Health Pysici } & 1 & 0.1 \mathrm{hr} / \mathrm{drum} & 30 & 31700 & \$ 57.79\end{array}$

Subtotal Records Review 1st Campaign

\section{Records Review 2nd campaign}

Includes batching, location/accesibility, possible hazards, pick lists, and 500 records review to support safety analysis \# of drums in campaign 1000

$\begin{array}{lllll}\text { Gen Sves } & 1 & 0.5 \mathrm{hr} / \text { drum } & 500 & 33200 \\ \text { SWITS } & 1 & 0.1 \mathrm{hr} / \mathrm{drum} & 100 & 32 \mathrm{~B} 00 \\ \text { 1st line spvsr } & 1 & 0.1 \mathrm{hr} / \text { drum } & 100 & 32 \mathrm{AOO} \\ \text { Health Pysici } & 1 & 0.1 \mathrm{hr} / \mathrm{drum} & 100 & 31700\end{array}$

$\$ 55.06 \quad \$ 27,530$

$\$ 55.06 \quad \$ 5,506$

Health Pysic

$0.1 \mathrm{hr} / \mathrm{drum}$

$\$ 84.67$

$\$ 57.79$

\section{Records Review 3rd campaign}

Includes batching, location/accesibility, possible hazards, pick lists

\# of drums in campaign

$\begin{array}{lll}\text { Gen Sves } & 1 & 0.5 \mathrm{hr} / \mathrm{drum} \\ \text { SWITS } & 1 & 0.1 \mathrm{hr} / \mathrm{drum} \\ \text { ist line spvsr } & 1 & 0.1 \mathrm{hr} / \mathrm{drum} \\ \text { Health Pysici } & 1 & 0.1 \mathrm{hr} / \mathrm{drum}\end{array}$

Subtotal Records Revlew 3rd Campaign

\section{Records Review 4th campaign}

Includes batching, location/accesibility, possible hazards, pick lists

$\#$ of drums in carnpaign

Gen Sves
SWITS
1 st line spvsr
Health Pysici
500

Subtotal Records Review 3rd Campaign

Records Review 5th campaign

Includes batching, location/accesibility, possible hazards, pick lists

\# of drums in campaign

Gen Svcs
SWITS
1st line spvsr
Health Pysici
2000

Subtotal Records Review 4th Campaign $\begin{array}{ll}750 & 33200 \\ 150 & 32 \mathrm{BO0} \\ 150 & 32 \mathrm{AOO}\end{array}$

0.1

$0.1 \mathrm{hr} / \mathrm{drum}$

$0.1 \mathrm{hr} / \mathrm{drum}$

$150 \quad 31700$

$\begin{array}{rr}350 & 33200 \\ 70 & 32800 \\ 70 & 32 A 00 \\ 70 & 31700\end{array}$

$\$ 55.06$

$\$ 55.06$

$\$ 84.67$

$\$ 57.79$
$\$ 19,271$

$\$ 3,854$

$\$ 5,927$

$\$ 4,045$

$\$ 33,097$

$\$ 41,295$

$\$ 8,259$

$\$ 12,701$

$\$ 8,669$

$\$ 70,923$

$$
\text { .... }
$$

$\$ 55,060$

$\$ 11,012$

$\$ 16,934$

$\$ 11,558$

$\$ 94,564$ 
Records Review 6th campaign

Includes batching, location/accesibility, possible hazards, pick lists

\# of drums in campaign 2000

Gen Svcs
SWITS
1st line spvsr
Health Pysici

$\begin{array}{ll}1 & 0.5 \mathrm{hr} / \mathrm{drum} \\ 1 & 0.1 \mathrm{hr} / \mathrm{drum} \\ 1 & 0.1 \mathrm{hr} / \mathrm{drum}\end{array}$

$200 \quad 32 \mathrm{~A} 00$

$\$ 55.06$

$\$ 55.06$

$\$ 84.67$

$0.1 \mathrm{hr} / \mathrm{drum}$

$200 \quad 31700$

$\$ 57.79$

$\$ 55,060$

$\$ 11,012$

$\$ 16,934$

$\$ 11,558$

Subtotal Records Review 5 th Campaign

$\$ 94,564$

Records Review 7th campaign

Includes batching, location/accesibility, possible hazards, pick lists

\# of drums in campaign

2000
Gen Svcs
SWITS
1st line spvsr
Health Pysici

1

$0.5 \mathrm{hr} / \mathrm{drum}$

$0.1 \mathrm{hr} / \mathrm{drum}$

$0.1 \mathrm{hr} / \mathrm{drum}$

$200 \quad 32 \mathrm{A00}$

$\$ 55.06$

$\$ 55.06$

$\$ 55,060$

$\$ 11,012$

$200 \quad 31700$

$\$ 84.67$

$\$ 57.79$

$\$ 16,934$

$\$ 11,558$

Subtotal Records Review 6th Campaign

$\$ 94,564$

\section{Records Review 8th campaign}

Includes batching, location/accesibility, possible hazards, pick lists

\# of drums in campaign 1000

Gen SvCs
SWITS
1 st line spvsr
Health Pysici

$\begin{array}{ll}1 & 0.5 \mathrm{hr} / \mathrm{drum} \\ 1 & 0.1 \mathrm{hr} / \mathrm{drum} \\ 1 & 0.1 \mathrm{hr} / \mathrm{drum} \\ 1 & 0.1 \mathrm{hr} / \mathrm{drum}\end{array}$

$\begin{array}{ll}500 & 33200 \\ 100 & 32 B 00 \\ 100 & 32 A 00 \\ 100 & 31700\end{array}$

$\$ 55.06$

$\$ 55.06$

$\$ 27.530$

$\$ 5,506$

$\$ 8,467$

$\$ 5,779$

Subtotal Records Review 7th Campaign

$\$ 47,282$

Grant Total Records Reviews

$\$ 416,082$ 


\section{Uncovered Retrieval}

\section{Task/Assumptions Resource Number Multiplier Units Total Hrs Org Unit Cost Total Cost}

\section{Retrieval 1st campaign}

\section{Retrieval Activities}

Includes retrieval, inspection, staging, labeling, providing to assay, slage LLW, and stage TRU waste

1 hour per drum

\# of drums in campaign

200

$\begin{array}{lrc}\text { NPO } & 3 & 1 \mathrm{hr} / \mathrm{drum} \\ \text { RCT } & 1.5 & 1 \mathrm{hr} / \mathrm{drum} \\ \text { 1st line spvsr } & 0.5 & 1 \mathrm{hr} / \mathrm{drum} \\ \text { Safety } & 0.5 & 1 \mathrm{hr} / \mathrm{drum} \\ \text { Crane Crew } & 0 & 3580 \$ / \text { day } \\ \text { Malerials } & 200 & 20 \$ \text { drum }\end{array}$

$\begin{array}{rr}600 & 63 A 00 \\ 300 & 63 A 00 \\ 100 & 32 A 00 \\ 100 & 32 A 00 \\ 0 & \end{array}$

$\$ 53.99$

$\$ 49.56 \quad \$ 14,868$

$\$ 84.67 \quad \$ 8,467$

$\$ 65.72 \quad \$ 6,572$

$1.2 \$ \$ \$ 0$

Mobile Assay campaign

Assay systern setup/testing

mob/demob fee

NPO

PO Contract

$80 \mathrm{hr}$

$40000 \$$

$80 \quad 63 A 00$

$\$ 53.99$

1.2

$\$ 4,319$

Assay Operations

Po Conracl

$500 \$ /$ drum

1.2

$\$ 120,000$

Overpacking

Fraction of drums requiring overpacking

NPO

RCT

Materials

$1 \mathrm{hr} / \mathrm{drum}$
$1 \mathrm{hr} / \mathrm{drum}$
200

$20 \quad 63 A 00$

$10 \quad 63 A 00$

$\$ 53.99$

$\$ 49.56$

1.2

$\$ 1.080$
$\$ 496$

$\$ 2,400$

Vent unvented drums

Assume venting is done at LLBG

Fraction of drums requiring venting

NPO

RCT

Indust. Hyg

Materials

Ship TRU Drums to CWC

Fraction of Relrieved Drums which are TRU

Review/Correct Paperwork Gen Svcs

Ship Waste to CWC

SWITS

$\begin{array}{ll}\text { NPO } \\ \text { RCT } \\ \text { Teamster } \\ \text { WMNW } \\ \text { Receive Waste at CWC } & \\ & \text { NPO } \\ \text { RCT } \\ \text { Malerials } \\ \text { SWITS }\end{array}$

Dispose orLLW in LLEG

Fraclion of Retrieved Drums which are LLW

Review/Correct Paperwork Gen Svcs

SWITS

Ship Waste/Place in LLBG

NPO

RCT

Teamster

SWITS

WMNW

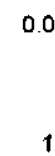

0.05

2

$\begin{aligned} & 1 \mathrm{hr} / \mathrm{drum} \\ & 1 \mathrm{hr} / \mathrm{drum} \\ &+1 \mathrm{hr} / \mathrm{drum} \\ & 50 \mathrm{~s} / \mathrm{drum}\end{aligned}$

$20 \quad 63 A 00$

$10 \quad 63 A 00$

$\$ 53.99$

$\$ 49.56$

1031300

$\$ 58.81$

1.2

$\$ 1,080$

$\$ 496$

$\$ 588$

$\$ 600$

0.5

$2 \mathrm{hr} / \mathrm{drum}$

$200 \quad 33200$

3332800

$\$ 55.06$

$\$ 55.06$

$\$ 11,012$

$0.33 \mathrm{hr} / \mathrm{drum}$

$10 \quad 63 A 00$

$0.1 \mathrm{hr} / \mathrm{drum}$

$0.1 \mathrm{hr} / \mathrm{drum}$

$10 \quad 63 \mathrm{AOO}$

$\$ 53.99$

$0.1 \mathrm{hr} / \mathrm{drum}$

$10 \quad 63700$

$\$ 49.56$

$\$ 39.98$

$\$ 80.00$

$\$ 1,817$

$0.1 \mathrm{hr} /$ drum

1008000

$\$ 53.99$

$0.1 \mathrm{hr} / \mathrm{drum}$

$0.1 \mathrm{he} / \mathrm{drum}$

$10 \quad 63 \mathrm{A00}$

$10 \quad 63 A 00$

$\$ 49.56$

1.2

20 \$/drum

$10 \quad 32800$

$\$ 55.06$

$\$ 540$

$\$ 496$

$\$ 400$

$\$ 800$

$\$ 540$

$\$ 496$

$\$ 4,800$

$\$ 551$

0.5

$0.5 \mathrm{hr} / \mathrm{drum}$

$50 \quad 33200$

$\$ 55.06$

$\$ 2,753$

$0.33 \mathrm{hr} / \mathrm{drum}$

$\$ 55.06$

$\$ 1,817$

$0.1 \mathrm{hr} / \mathrm{drum}$

0.1 hridrum

$33 \quad 32800$

$\$ 53.99$

10 63A00

$10 \quad 63 A 00$

1063700

$10 \quad 32 \mathrm{BO0}$

$\$ 49.56$

$\$ 55.06$

$0.1 \mathrm{hr} / \mathrm{d}$ rum

1008000

$\$ 80.00$

$\$ 274,965$

Subtotal 1 st Campaign

$80 \mathrm{hrs}$

$80 \mathrm{hrs}$

$80 \mathrm{hrs}$

$\begin{array}{ll}80 & 32 K 00 \\ 80 & 32800 \\ 80 & 33200\end{array}$

$\$ 55.09$

$\$ 5,207$

$\$ 4,262$

$\$ 4,405$

Subtotal Evaluate 1st Campaign 


\section{Retrieval 2nd campaign}

\section{Retrieval Activities}

Includes retrieval, inspection, staging, labeling, providing to assay, stage LLW, and stage TRU waste 1 hour per drum

\# of drums in campaign

$\begin{array}{lrc} & & \\ \text { NPO } & 300 & 1 \mathrm{hr} / \mathrm{drum} \\ \text { RCT } & 1.5 & 1 \mathrm{hr} / \mathrm{drum} \\ \text { 1st line spvss } & 0.5 & 1 \mathrm{hr} / \mathrm{drum} \\ \text { Safety } & 0.5 & 1 \mathrm{hr} / \mathrm{drum} \\ \text { Crane Crew } & 0 & 3580 \$ / \text { day } \\ \text { Malerials } & 400 & 20 \$ / \text { drum }\end{array}$

$$
\begin{array}{rr}
1200 & 63 A 00 \\
600 & 63 A 00 \\
200 & 32 A 00 \\
200 & 32 A 00
\end{array}
$$

$\$ 53.99$

$\$ 64,788$

$\$ 29,736$

$\$ 84.67 \quad \$ 16,934$

$\$ 65.72 \$ 13,144$

$1.2 \$ 0$

$1.2 \$ 9,600$

Mobile Assay campalgn

Assay system setup/testing

NPO

mob/demob fee POContract

Assay Operations

PO Conract

$\begin{array}{lr}1 & 80 \mathrm{hr} \\ 1 & 40000 \$\end{array}$

400

$500 \$ /$ drum

$8063 A 00$

$\begin{array}{rr}\$ 53.99 & \$ 4,319 \\ 1.2 & \$ 48,000 \\ 1.2 & \$ 240,000\end{array}$

Overpacking

Fraction of drums requiring overpacking

NPO

RCT

Materials

0.05
2
1

$$
1 \mathrm{hr} / \mathrm{drum}
$$

$40 \quad 63 A 00$

$20 \quad 63 A 00$

$\$ 53.99$

$\$ 49.56$

$\$ 2,160$

$\$ 991$

$\$ 4,800$

Vent unvented drums

Assume venting is done al LLBG

Fraction of drums requiring venting

NPO

RCT

Indust. Hyg.

Materials

Ship TRU Drums to CWC

Fraction of Retrieved Drums which are TRU

Review//Correct Paperwork Gen Sycs

Ship Waste to CWC

SWITS

NPO
RCT
Teamster
WMNW

Receive Waste at CWC

$$
\begin{aligned}
& \text { NPO } \\
& \text { RCT } \\
& \text { Materials } \\
& \text { SWITS }
\end{aligned}
$$

$$
\begin{aligned}
& 1 \mathrm{hr} / \mathrm{drum} \\
& 1 \mathrm{hr} / \mathrm{drum} \\
& 1 \mathrm{hr} / \mathrm{drum}
\end{aligned}
$$

50 \$idrum

$\begin{array}{ll}40 & 63 A 00 \\ 20 & 63 A 00 \\ 20 & 31300\end{array}$

0.5

$0.33 \mathrm{hr} / \mathrm{drum}$

$400 \quad 33200$

$66 \quad 32800$

$\$ 55.06$

$20 \quad 63 A 00$

$0.1 \mathrm{ht} / \mathrm{drum}$

$0.1 \mathrm{hr} / \mathrm{drum}$

$20 \quad 63 A 00$

$0.1 \mathrm{hr} / \mathrm{drum}$

$0.1 \mathrm{hr} / \mathrm{drum}$

$20 \quad 63700$

$20 \quad 08000$

$\$ 53.99$

$\$ 49.56$

$\$ 39.98$

$\$ 80.00$

$20 \quad 63 A 00$

$0.1 \mathrm{hr} / \mathrm{drum}$

$0.1 \mathrm{hr} / \mathrm{drum}$

20 \$/drum

$0.1 \mathrm{hr} / \mathrm{drum}$

$20 \quad 63400$

$\$ 53.99$

$\$ 49.56$

1.2

$20 \quad 32800$

$\$ 55.06$

$\$ 2,160$

$\$ 991$

$\$ 1,176$

$\$ 1,200$

Dispose of LLW in LLBG

Fraction of Retrieved Drums which are LLW

Review/Correct Paperwork Gen Svcs SWITS

Ship Waste/Place in LLBG

$$
\text { NPO }
$$

RCT

Teamster

SWITS

WMNW
0.5

$0.5 \mathrm{hr} / \mathrm{drum}$

$0.33 \mathrm{hr} / \mathrm{drum}$

$0.1 \mathrm{hr} / \mathrm{drum}$

$0.1 \mathrm{hr} / \mathrm{drum}$

$0.1 \mathrm{hr} / \mathrm{drum}$

$0.1 \mathrm{hr} / \mathrm{drum}$
$0.1 \mathrm{hr} / \mathrm{drum}$
$100 \quad 33200$

6632800

$20 \quad 63 A 00$

$20 \quad 63 A 00$

$20 \quad 63700$

$20 \quad 32 \mathrm{~B} 00$

2008000
$\$ 55.06$

$\$ 55.06$

$\$ 53.99$

$\$ 49.56$

$\$ 39.98$

$\$ 55.06$

$\$ 80.00$
$\$ 22,024$

$\$ 3,634$

$\$ 1,080$

$\$ 991$

$\$ 800$

$\$ 1,600$

$\$ 1,080$

$\$ 991$

$\$ 9,600$

$\$ \$, 101$

$\$ 5,506$

$\$ 3,634$

$\$ 1,080$

$\$ 991$

$\$ 800$

$\$ 1.101$

$\$ 1,600$

Subtotal 2nd Campaign

$\$ 497,612$

\section{Retrieval 3rd campaign}

Retrieval Activities

Includes retrieval, inspection, staging, labeling, providing to assay, stage LLW, and stage TRU waste

1 hour per drum .

\# of drums in campaign

NPO
RCT
1st líne spvst

3
1.5
0.5

$1 \mathrm{hr} / \mathrm{drum}$

$1 \mathrm{hr} / \mathrm{drum}$
$210063 A 00$

$1050 \quad 63 \mathrm{A00}$

$35032 \mathrm{A00}$
$\$ 53.99$

$\$ 49.56$

$\$ 84.67$
$\$ 113,379$

$\$ 52,038$

$\$ 29,635$ 


\section{Salety \\ Crane Crew \\ Materials}

Sky Track

Procure Sky Track Vehicle Materials

Moblle Assay campaign

Assay system setup/testing

$\begin{array}{ll}\text { mob/demob fee } & \text { PO Contract }\end{array}$

Assay Operations

PO Conracl

Overpacking

Fraction of drums requiring overpacking

NPO

RCT

Materials

Vent unvented drums

Assume venting is done al LLBG

Fraction of drums requiring venting

NPO

RCT

Indust. Hyg

Materials

Ship TRU Drums to CWC

Fraction of Retrieved Drums which are TRU

Review/Correct Paperwork Gen Svcs

SWITS

Ship Waste to CWC

NPO

RCT

Teamster WMNW

Receive Waste at CWC

NPO

RCT

Materials

SWITS

Dispose of LLW in LLBG

Fraction of Retrieved Drums which are LLW

Review/Correct Paperwork Gen Svcs SWITS

Ship Waste/Place in LLBG

NPO

RCT

Teamster

SWITS

WMNW

Subtotal 3rd Campaign

$1 \mathrm{hr} / \mathrm{drum}$

$1 \mathrm{hr} / \mathrm{drum}$

200 \$/drum

$\begin{array}{ll}70 & 63 A 00 \\ 35 & 63 A 00\end{array}$

$\$ 53.99$

$\$ 49.56$

1.2

$\$ 3,779$

$\$ 1,735$

$\$ 8,400$

0.05

$1 \mathrm{hr} / \mathrm{drum}$
$1 \mathrm{hr} / \mathrm{drum}$
$1 \mathrm{hr} / \mathrm{drum}$

$70 \quad 63 A 00$

$35 \quad 63 \mathrm{A00}$

3531300

50 \$/drum

$\$ 53.99$

$\$ 49.56$

$\$ 58.81$

1.2

$\$ 3,779$

$\$ 1,735$

$\$ 2,058$

$\$ 2,100$

$2 \mathrm{hr} / \mathrm{drum}$ $0.33 \mathrm{hr} / \mathrm{drum}$

$700 \quad 33200$

115.532800

$\$ 55.06$

$\$ 55.06$

$\$ 38,542$

$0.1 \mathrm{hr} /$ drum

$0.1 \mathrm{hr} / \mathrm{drum}$

$0.1 \mathrm{hr} / \mathrm{drum}$

$35 \quad 63 A 00$

$35 \quad 63 A 00$

3563700

3508000

$\$ 53.99$

$\$ 49.56$

$\$ 39.98$

$\$ 30.00$

$35 \quad 63 \mathrm{AO0}$

$0.1 \mathrm{hr} /$ drum

$0.1 \mathrm{hr} / \mathrm{drum}$

$20 \$ / d r u m$

$0.1 \mathrm{hr} / \mathrm{drum}$

$3563 A 00$

$35 \quad 32800$

$\$ 53.99$

$\$ 49.56$

1.2

$\$ 55.06$

$\$ 6,359$

$\$ 1,890$

$\$ 1.735$

$\$ 1,399$

$\$ 2,800$

$\$ 1,890$

$\$ 1,735$

$\$ 16,800$

$\$ 1,927$

$0.5 \mathrm{hr} / \mathrm{d} r u m$

$175 \quad 33200$

$\$ 55.06$

$\$ 55.06$

$\$ 9,636$

$0.33 \mathrm{hr} / \mathrm{drum}$

115.532800

$\$ 53.99$

$0.1 \mathrm{hr} / \mathrm{drum}$

$35 \quad 63 A 00$

$35 \quad 63 A 00$

$0.1 \mathrm{hr} / \mathrm{drum}$

$0.1 \mathrm{hr} / \mathrm{drum}$

$0.1 \mathrm{hr} / \mathrm{drum}$

3563700

$\$ 49.56$

$\$ 39.98$

$\$ 55.06$

3508000 - $\$ 80.00$

$\$ 6,359$

$\$ 1.890$

$\$ 1.735$

$\$ 1.399$

$\$ 1,927$

$\$ 2,800$

$\$ 999,581$

$\$ 1,786,032$

\section{Grand Total Uncovered Retrieval}




\section{Covered Retrieval}

\section{Task/Assumptions}

Retrieval 4th campaign
Resource Number Multiplier Units Total Hrs Org Unit Cost Total Cost

Surveying

$\begin{array}{lllllll}\text { NPO } & 1 & 20 \mathrm{hrs} & 20 & 63 \mathrm{A00} & \$ 53.99 & \$ 1,080 \\ \text { Engineering } & 1 & 20 \mathrm{hrs} & 20 & 32900 & \$ 64.58 & \$ 1,292\end{array}$

Excavation

NPO
RCT
1 st line spvsr
HEO
Heavy Equip
Guzzler

$\begin{array}{rc}1 & 120 \mathrm{hrs} \\ 1 & 120 \mathrm{hrs} \\ 1 & 60 \mathrm{hrs} \\ 1 & 120 \mathrm{hrs} \\ 10 & 1000 \$ / \text { day } \\ 85 & 250 \$ / \text { day }\end{array}$
$120 \quad 63 A 00$
$120 \quad 63 A 00$
$60 \quad 32 A 00$
$120 \quad 08000$

$\$ 53.99$

$\$ 49.56$

$\$ 84.67$

$\$ 64.58$

1.2

1.2

$\$ 6,479$

$\$ 5,947$

$\$ 5,080$

$\$ 7,750$

$\$ 12,000$

$\$ 25,500$

Retrieval Activities

Includes retrieval, inspection, staging, labeling, providing to assay, stage LLW, and stage TRU waste

1 hour per drum

\# of drums in campaign 1000

$\begin{array}{lrr}\text { NPO } & 3 & 1 \mathrm{hr} / \mathrm{drum} \\ \text { RCT } & 2 & 1 \mathrm{hr} / \mathrm{drum} \\ \text { 1st line spvsr } & 0.5 & 1 \mathrm{hr} / \mathrm{drum} \\ \text { Safety } & 0.5 & 1 \mathrm{hr} / \mathrm{drum} \\ \text { Crane Crew } & 20 & 3580 \mathrm{\$} / \mathrm{day} \\ \text { Materials } & 1000 & 20 \$ / \mathrm{drum}\end{array}$

$\begin{array}{rr}3000 & 63 A 00 \\ 2000 & 63 A 00 \\ 500 & 32 A 00 \\ 500 & 32 A 00 \\ 71600 & \end{array}$

$\$ 53.99$

$\$ 49.56$

$\$ 84.67$

$\$ 65.72$

1.2

1.2

$\$ 161,970$

$\$ 99,120$

$\$ 42,335$

$\$ 32,860$

$\$ 85,920$

$\$ 24,000$

Mobile Assay campaign

Assay system selup/testing

$$
\text { mob/demob fee }
$$

NPO
PO Contract

$80 \mathrm{hr}$

$140000 \$$

$80 \quad 63 A 00$

$\$ 53.99$
1.2

$\$ 4,319$

$\$ 48,000$

Assay Operations

PO Conract

1000

$500 \$ /$ drum

1.2

$\$ 600,000$

Overpacking

Fraction of drums requiring overpacking

NPO
RCT
Materias

0.2

$\begin{array}{rr}2 & 1 \mathrm{hr} / \mathrm{drum} \\ 1 & 1 \mathrm{hr} / \mathrm{drum} \\ 200 & -200 \$ / \text { drum }\end{array}$

$400 \quad 63 A 00$

$200 \quad 63 A 00$

$\$ 53.99$

$\$ 49.56$

$\$ 21,596$

$\$ 9,912$

$\$ 48,000$

Vent unvented drums

Assume venting is done at LLBG

Fraction of drums requiring venting

NPO

RCT

Indust. Hyg

Materials

$\begin{array}{rr}0.1 & \\ 2 & 1 \mathrm{hr} / \mathrm{drum} \\ 1 & 1 \mathrm{hr} / \mathrm{drum} \\ 1 & 1 \mathrm{hr} / \mathrm{drum} \\ 100 & 50 \$ / \mathrm{drum}\end{array}$

$\begin{array}{ll}200 & 63 A 00 \\ 100 & 63 A 00 \\ 100 & 31300\end{array}$

$\$ 53.99$

$\$ 49.56$

$\$ 58.81$

$\$ 10,798$

$\$ 4,956$

$\$ 5,881$

1.2

$\$ 6,000$

Ship TRU Drums to CWC

Fraction of Retrieved Drums which are TRU

Review/Correcl Paperwork

Gen Sves

Ship Waste to CWC

SWITS

0.5
1
1

$2 \mathrm{hr} / \mathrm{drum}$
$0.33 \mathrm{hr} / \mathrm{drum}$

$1000 \quad 33200$

16532800

$\$ 55.06$ ..

$125 \quad 63 A 00$

$125 \quad 63 A 00$

12563700

$0.25 \mathrm{hr} / \mathrm{drum}$

$0.25 \mathrm{hr} / \mathrm{drum}$

$0.25 \mathrm{hr} / \mathrm{drum}$

Teamster

Receive Waste at CWC

WMNW

$0.25 \mathrm{hr} / \mathrm{drum}$

12508000

$\$ 55.06$

$\$ 55,060$

$\$ 9,085$

$\$ 53.99$

$\$ 6,749$

$\$ 49.56$

$\$ 6,195$

$\$ 4,998$

$\$ 80.00$

$\$ 10,000$

NPO

RCT

Materials

$0.25 \mathrm{hr} / \mathrm{drum}$

125. $63 A 00$

$\$ 53.99$

$\$ 6,749$

$0.25 \mathrm{hr} / \mathrm{drum}$

$20 \$ /$ drum

$125 \quad 63 A 00$

$\$ 49.56$

$\$ 6,195$

1000

$0.1 \mathrm{hr} / \mathrm{drum}$

$50 \quad 32800$ 
Dispose of LLW in LLBG

Fraction of Retrieved Drums which are LLW

Review/Correct Paperwork

Gen Svcs

SWITS

Ship Waste/Place in LLBG

NPO

RCT

Teamster

SWITS

WMNW

$\begin{array}{rr}0.5 & \\ 1 & 0.5 \mathrm{hr} / \mathrm{drum} \\ 1 & 0.33 \mathrm{hr} / \mathrm{drum} \\ & \\ 1 & 0.25 \mathrm{hr} / \mathrm{drum} \\ 1 & 0.25 \mathrm{hr} / \mathrm{drum} \\ 1 & 0.25 \mathrm{hr} / \mathrm{drum} \\ 1 & 0.1 \mathrm{hr} / \mathrm{drum} \\ 1 & 0.25 \mathrm{hr} / \mathrm{drum}\end{array}$
$250 \quad 33200$
$16532 \mathrm{~B} 00$
$125 \quad 63 A 00$
$125 \quad 63 \mathrm{AO0}$
$50 \quad 32 \mathrm{~B} 00$
12508000

$\$ 55.06$

$\$ 55.06$

$\$ 13,765$

$\$ 53.99$

$\$ 49.56$

$\$ 39.98$

$\$ 55.06$

$\$ 80.00$

\title{
Retrieval 5th campaign
}

\author{
Excavation
}

$\begin{array}{lrc}\text { NPO } & 1 & 120 \mathrm{hrs} \\ \text { RCT } & 1 & 120 \mathrm{hrs} \\ \text { 1st line spvsr } & 1 & 60 \mathrm{hrs} \\ \text { HEO } & 1 & 120 \mathrm{hrs} \\ \text { Heavy Equip } & 10 & 1000 \$ / \text { day } \\ \text { Guzzler } & 85 & 250 \text { \$/day }\end{array}$

$\begin{array}{rr}120 & 63 A 00 \\ 120 & 63 A 00 \\ 60 & 32 A 00\end{array}$

$120 \quad 08000$

$\begin{array}{rr}\$ 53.99 & \$ 6,479 \\ \$ 49.56 & \$ 5,947 \\ \$ 84.67 & \$ 5,080 \\ \$ 64.58 & \$ 7,750 \\ 1.2 & \$ 12,000 \\ 1.2 & \$ 25,500\end{array}$

Retrieval Activities

includes retrieval, inspection, staging, labeling, providing to assay, stage LLW, and stage TRU waste

1 hour per drum

\# of drums in campaign 1700

NPO

RCT

1 st line spvsr

Safety

Crane Crew

Materials

Assay system setup/testing

mob/demob fee

NPO

PO Contract

PO Conract

Assay Operations

c!

3
2
0.5
0.5
20
1700

$\begin{array}{rl}1 & \mathrm{hr} / \mathrm{drum} \\ 1 & \mathrm{hr} / \mathrm{drum} \\ 1 \mathrm{hr} / \mathrm{drum} \\ 1 \mathrm{hr} / \mathrm{drum} \\ 3580 \mathrm{\$} / \text { day }\end{array}$

$20 \$ /$ drum

$80 \mathrm{hr}$

$40000 \$$

$500 \$ /$ drum
Mobile Assay campaign

$\begin{array}{rr}\$ 53.99 & \$ 275,349 \\ \$ 49.56 & \$ 168,504 \\ \$ 84.67 & \$ 71,970 \\ \$ 65.72 & \$ 55,862 \\ 1.2 & \$ 85,920 \\ 1.2 & \$ 40,800\end{array}$

$80 \quad 63400$

$\$ 53.99$

1.2

1.2

$\$ 1,020,000$

Overpacking

Fraction of drums requiring overpacking

NPO

RCT

Materials

0.2
2
1
340
$1 \mathrm{hr} / \mathrm{drum}$
1 hr/drum
$200 \$ /$ drum

$\begin{array}{ll}680 & 63 A 00 \\ 340 & 63 A 00\end{array}$

$\$ 53.99$

$\$ 49.56$

1.2

$\$ 36,713$

$\$ 16,850$

$\$ 81,600$

Vent unvented drums

Assume venting is done at LLBG

Fraction of drums requiring venting

NPO

RCT

Indust. Hyg.

Materials

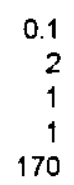

1 hr/drum

$1 \mathrm{hr} / \mathrm{drum}$

$1 \mathrm{hr} / \mathrm{drum}$

$50 \$ / d r u m$

$\begin{array}{ll}340 & 63 A 00 \\ 170 & 63 A 00 \\ 170 & 31300\end{array}$

$\$ 53.99$

$\$ 49.56$

$\$ 58.81$

1.2

$\$ 18,357$

$\$ 8,425$

$\$ 9,998$

$\$ 10,200$

Ship TRU Drums to CWC

Fraction of Retrieved Drums which are TRU

Review/Correct Paperwork Gen Svcs SWITS

Ship Waste to CWC

NPO
RCT
Teamster

$2 \mathrm{hr} / \mathrm{drum}$

$0.33 \mathrm{hr} / \mathrm{drum}$

$0.25 \mathrm{he} / \mathrm{drum}$

$0.25 \mathrm{hr} / \mathrm{drum}$

$0.25 \mathrm{hr} / \mathrm{drum}$
$1700 \quad 33200$

280.532800

$212.5 \quad 63 A 00$

$212.5 \quad 63 \mathrm{A00}$

212.563700 


\begin{tabular}{|c|c|c|c|c|c|c|c|}
\hline 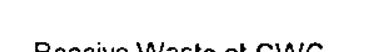 & WMNW & 1 & $0.25 \mathrm{hr} / \mathrm{drum}$ & 212.5 & 08000 & $\$ 80.00$ & $\$ 17,000$ \\
\hline & NPO & 1 & $0.25 \mathrm{hr} / \mathrm{drum}$ & 212.5 & $63 A 00$ & $\$ 53.99$ & $\$ 11.473$ \\
\hline & RCT & 1 & 0.25 hridrum & 212.5 & $63 A 00$ & $\$ 49.56$ & $\$ 10,532$ \\
\hline & Materials & 1700 & $20 \$ /$ drum & & & 1.2 & $\$ 40,800$ \\
\hline & SWITS & 1 & $0.1 \mathrm{hr} / \mathrm{drum}$ & 85 & $32 \mathrm{~B} 00$ & $\$ 55.06$ & $\$ 4,680$ \\
\hline \multicolumn{8}{|l|}{ Dispose of LLW in LLBG } \\
\hline \multicolumn{2}{|c|}{ Fraction of Retrieved Drums which are LLW } & 0.5 & & & & & \\
\hline \multirow[t]{2}{*}{ Review/Correct Paperwork } & Gen Sves & 1 & $0.5 \mathrm{hr} / \mathrm{drum}$ & 425 & 33200 & $\$ 55.06$ & $\$ 23,401$ \\
\hline & SWITS & 1 & $0.33 \mathrm{hr} / \mathrm{drum}$ & 280.5 & $32 \mathrm{~B} 00$ & $\$ 55.06$ & $\$ \$ 5,44$ \\
\hline \multicolumn{8}{|l|}{ Ship Waste/Place in LLBG } \\
\hline & NPO & 1 & $0.25 \mathrm{hr} / \mathrm{drum}$ & 212.5 & $63 A 00$ & $\$ 53.99$ & $\$ 11,473$ \\
\hline & RCT & 1 & $0.25 \mathrm{hr} / \mathrm{drum}$ & 212.5 & $63 A 00$ & $\$ 49.56$ & $\$ 10,532$ \\
\hline & Teamster & 1 & $0.25 \mathrm{hr} / \mathrm{drum}$ & 212.5 & 63700 & $\$ 39.98$ & $\$ 8,496$ \\
\hline & SWITS & 1 & $0.1 \mathrm{hr} / \mathrm{drum}$ & 85 & 32B00 & $\$ 55.06$ & $\$ 4,680$ \\
\hline & WMNW & 1 & $0.25 \mathrm{hr} / \mathrm{drum}$ & 212.5 & 08000 & $\$ 80.00$ & $\$ 17,000$ \\
\hline
\end{tabular}

\section{Retrieval 6th campaign}

Excavation

$\begin{array}{lrrrrrr}\text { NPO } & 1 & 120 \mathrm{hrs} & 120 & 63 A 00 & \$ 53.99 & \$ 6,479 \\ \text { RCT } & 1 & 120 \mathrm{hrs} & 120 & 63 A 00 & \$ 49.56 & \$ 5,947 \\ 1 \text { st line spvsr } & 1 & 60 \mathrm{hrs} & 60 & 32 \mathrm{~A} 00 & \$ 84.67 & \$ 5,080 \\ \text { HEO } & 1 & 120 \mathrm{hrs} & 120 & 08000 & \$ 64.58 & \$ 7,750 \\ \text { Heavy Equip } & 10 & 1000 \$ \text { /day } & & & 1.2 & \$ 12,000 \\ \text { Guzzler } & 85 & 250 \$ \text { day } & & & 1.2 & \$ 25,500\end{array}$

Retrieval Activities

Includes retrieval, inspection, staging, labeling, providing to assay, stage LLW, and stage TRU waste

1 hour per drum

\# of drums in campaign 2000

$\begin{array}{lrr}\text { NPO } & 3 & 1 \mathrm{hr} / \mathrm{drum} \\ \text { RCT } & 2 & 1 \mathrm{hr} / \mathrm{drum} \\ \text { 1st line spvsr } & 0.5 & 1 \mathrm{hr} / \mathrm{drum} \\ \text { Safety } & 0.5 & 1 \mathrm{hr} / \text { drum } \\ \text { Crane Crew } & 20 & 3580 \$ \text { day }\end{array}$

$6000 \quad 63 A 00$

$400063 A 00$

$1000 \quad 32400$

$1000 \quad 32 A 00$

Crane Crew

$20 \$ /$ drum

71600

Materials

2000

$20 \$ /$ drum

Mobile Assay campaign

Assay system selup/testing

$$
\text { mob/demob fee }
$$

NPO

PO Contract

$80 \mathrm{hr}$

$40000 \$$

Assay Operations

PO Conract

2000

$500 \$ /$ drum

Overpacking

Fraction of drums requiring overpacking

NPO

RCT

Materials

Vent unvented drums

Assume venting is done at $L L B G$

Fraction of drums requiring venting

NPO
RCT
Indust. Hyg.
Materials

200

Ship TRU Drums to CWC

Fraction of Retrieved Drums which are TRU
0.2

2

1
400

$1 \mathrm{hr} / \mathrm{drum}$

$1 \mathrm{hr} / \mathrm{drum}$

200 \$/drum
$\$ 53.99$

$\$ 49.56$

$\$ 84.67$

$\$ 65.72$

1.2

1.2
$\$ 323,940$ $\$ 198,240$

$\$ 84,670$

$\$ 65,720$

$\$ 85,920$

$\$ 48,000$
$800 \quad 63 A 00$

$400 \quad 63 A 00$
$80 \quad 63 A 00$

$\$ 53.99$

1.2

1.2

$\$ 53.99$ $\$ 49.56$

1.2
$\$ 43,192$ $\$ 19,824$ $\$ 96,000$
$\$ 4,319$

$\$ 48,000$

$\$ 1,200,000$ 


\begin{tabular}{|c|c|c|c|c|c|c|c|}
\hline Review/Correct Paperwork & $\begin{array}{l}\text { Gen Svcs } \\
\text { SWITS }\end{array}$ & $\begin{array}{l}1 \\
1\end{array}$ & $\begin{array}{r}2 \mathrm{hr} / \mathrm{drum} \\
0.33 \mathrm{hr} / \mathrm{drum}\end{array}$ & $\begin{array}{r}2000 \\
330\end{array}$ & $\begin{array}{l}33200 \\
32800\end{array}$ & $\begin{array}{l}\$ 55.06 \\
\$ 55.06\end{array}$ & $\begin{array}{r}\$ 110,120 \\
\$ 18,170\end{array}$ \\
\hline \multicolumn{8}{|l|}{ Ship Waste to CWC } \\
\hline & NPO & 1 & $0.25 \mathrm{hr} / \mathrm{drum}$ & 250 & $63 A 00$ & $\$ 53.99$ & $\$ 13,498$ \\
\hline & $\mathrm{RCT}$ & 1 & $0.25 \mathrm{hr} / \mathrm{drum}$ & 250 & $63 A 00$ & $\$ 49.56$ & $\$ 12,390$ \\
\hline & Teamster & 1 & $0.25 \mathrm{hr} / \mathrm{drum}$ & 250 & 63700 & $\$ 39.98$ & $\$ 9,995$ \\
\hline & WMNW & 1 & $0.25 \mathrm{hr} / \mathrm{drum}$ & 250 & 08000 & $\$ 80.00$ & $\$ 20,000$ \\
\hline \multicolumn{8}{|l|}{ Receive Waste at CWC } \\
\hline & NPO & 1 & $0.25 \mathrm{hr} / \mathrm{drum}$ & 250 & $63 A 00$ & $\$ 53.99$ & $\$ 13,498$ \\
\hline & RCT & 1 & $0.25 \mathrm{hr} / \mathrm{drum}$ & 250 & $63 A 00$ & $\$ 49.56$ & $\$ 12,390$ \\
\hline & Materials & 2000 & $20 \$ /$ drum & & & 1.2 & $\$ 48,000$ \\
\hline & SWITS & 1 & $0.1 \mathrm{hr} / \mathrm{drum}$ & 100 & $32 \mathrm{~B} 00$ & $\$ 55.06$ & $\$ 5,506$ \\
\hline \multicolumn{8}{|l|}{ Dispose of $L L W$ in $L L B G$} \\
\hline \multicolumn{2}{|c|}{ Fraction of Retrieved Drums which are LLW } & 0.5 & & & & & \\
\hline \multirow[t]{2}{*}{ Review/Correct Paperwork } & Gen Sves & 1 & $0.5 \mathrm{hr} / \mathrm{drum}$ & 500 & 33200 & $\$ 55.06$ & $\$ 27,530$ \\
\hline & SWITS & 1 & $0.33 \mathrm{hr} / \mathrm{drum}$ & 330 & $32 \mathrm{~B} 00$ & $\$ 55.06$ & $\$ 18,170$ \\
\hline \multicolumn{8}{|l|}{ Ship Waste/Place in LLBG } \\
\hline & NPO & 1 & $0.25 \mathrm{hr} / \mathrm{drum}$ & 250 & $63 \mathrm{~A} 00$ & $\$ 53.99$ & $\$ 13,498$ \\
\hline & RCT & 1 & $0.25 \mathrm{hr} / \mathrm{drum}$ & 250 & $63 A 00$ & $\$ 49.56$ & $\$ 12,390$ \\
\hline & Teamster & 1 & $0.25 \mathrm{hr} / \mathrm{drum}$ & 250 & 63700 & $\$ 39.98$ & $\$ 9,995$ \\
\hline & SWITS & 1 & $0.1 \mathrm{hr} / \mathrm{drum}$ & 100 & 32800 & $\$ 55.06$ & $\$ 5,506$ \\
\hline & WMNW & 1 & $0.25 \mathrm{hr} / \mathrm{drum}$ & 250 & 08000 & $\$ 80.00$ & $\$ 20,000$ \\
\hline
\end{tabular}

Subtotal 6 th Campaign

$\$ 2,706,505$

\section{Retrieval 7th campaign}

Excavation

$\begin{array}{lrc}\text { NPO } & 1 & 120 \mathrm{hrs} \\ \text { RCT } & 1 & 120 \mathrm{hrs} \\ \text { 1st line spvsr } & 1 & 60 \mathrm{hrs} \\ \text { HEO } & 1 & 120 \mathrm{hrs} \\ \text { Heavy Equip } & 10 & 1000 \$ / \text { day } \\ \text { Guzzler } & 85 & 250 \$ / \text { day }\end{array}$

$120 \quad 63 A 00$

$120 \quad 63 A 00$

$60 \quad 32400$

$120 \quad 08000$

$\begin{array}{rr}\$ 53.99 & \$ 6,479 \\ \$ 49.56 & \$ 5,947 \\ \$ 84.67 & \$ 5,080 \\ \$ 64.58 & \$ 7,750 \\ 1.2 & \$ 12,000 \\ 1.2 & \$ 25,500\end{array}$

Retrieval Activities

Includes retrieval, inspection, staging, labeling, providing to assay, stage LLW, and stage TRU waste

1 hour per drum

\# of drums in campaign 2000

$\begin{array}{lrr}\text { NPO } & 3 & 1 \mathrm{hr} / \mathrm{drum} \\ \text { RCT } & 2 & 1 \mathrm{hr} / \mathrm{drum} \\ 1 \text { st line spvsr } & 0.5 & 1 \mathrm{hr} / \mathrm{drum} \\ \text { Salety } & 0.5 & 1 \mathrm{hr} / \mathrm{drum} \\ \text { Crane Crew } & 20 & 3580 \$ / \text { day } \\ \text { Materials } & 2000 & 20 \text { \$/drum }\end{array}$

$6000 \quad 63400$

$4000 \quad 63 A 00$

$1000 \quad 32 A 00$

$1000 \quad 32 \mathrm{AOO}$

71600

$\$ 53.99$

$\$ 49.56$

$\$ 84.67$

$\$ 65.72$

1.2

1.2

$\$ 323,940$

$\$ 198,240$

$\$ 84,670$

$\$ 65,720$

$\$ 85,920$

$\$ 48,000$

Mobile Assay campaign

Assay system setup/testing mob/demob fee

NPO

$80 \mathrm{hr}$

$80 \quad 63 A 00$

$\$ 4,319$

PO Contract

$40000 \$$

PO Conract

2000

$500 \$ / d r u m$

$\$ 53.99$

$\$ 48,000$

Assay Operations

1.2

$\$ 1,200,000$

Overpacking

Fraction of drums requiring overpacking

NPO

RCT

Materials

$\begin{array}{rr}0.2 & \\ 2 & 1 \mathrm{hr} / \mathrm{drum} \\ 1 & 1 \mathrm{hr} / \mathrm{drum} \\ 400 & 200 \$ / \mathrm{drum}\end{array}$

$800 \quad 63 A 00$

$\$ 53.99$

$\$ 43,192$

$400 \quad 63 \mathrm{AOO}$

$\$ 49.56$

$\$ 19,824$

1.2

$\$ 96,000$

Vent unvented drums

Assume venting is done at LLBG

Fraction of drums requiring venting

0.1
$1 \mathrm{hr} / \mathrm{drum}$

400

$63 A 00$ 


$\begin{array}{lrrrrrr}\text { RCT } & 1 & 1 \mathrm{hr} / \mathrm{drum} & 200 & 63 \mathrm{~A} 00 & \$ 49.56 & \$ 9,912 \\ \text { Indust. Hyg. } & 1 & 1 \mathrm{hr} / \mathrm{drum} & 200 & 31300 & \$ 58.81 & \$ 11,762 \\ \text { Materials } & 200 & 50 \mathrm{\$} / \mathrm{drum} & & & 1.2 & \$ 12,000\end{array}$

Ship TRU Drums to CWC

Fraction of Retrieved Drums which are TRU

Review/Correct Paperwork Gen Svcs

SWITS

Ship Waste to CWC

$\begin{array}{ll}\text { Ship Waste to CWC } & \text { NPO } \\ \text { RCT } \\ \text { Teamster } \\ \text { WMNW } \\ \\ \text { Receive Waste at CWC } & \text { NPO } \\ & \text { RCT } \\ & \text { Materials } \\ & \text { SWITS }\end{array}$

\begin{tabular}{|c|c|c|c|c|c|}
\hline \multicolumn{6}{|l|}{0.5} \\
\hline 1 & $2 \mathrm{hr} / \mathrm{drum}$ & 2000 & 33200 & $\$ 55.06$ & $\$ 110,120$ \\
\hline 1 & $0.33 \mathrm{hr} / \mathrm{drum}$ & 330 & $32 \mathrm{~B} 00$ & $\$ 55.06$ & $\$ 18,170$ \\
\hline 1 & $0.25 \mathrm{hr} / \mathrm{drum}$ & 250 & $63 A 00$ & $\$ 53.99$ & $\$ 13,498$ \\
\hline 1 & $0.25 \mathrm{hr} / \mathrm{drum}$ & 250 & $63 A 00$ & $\$ 49.56$ & $\$ 12,390$ \\
\hline 1 & $0.25 \mathrm{hr} / \mathrm{drum}$ & 250 & 63700 & $\$ 39.98$ & $\$ 9,995$ \\
\hline 1 & $0.25 \mathrm{hr} / \mathrm{drum}$ & 250 & 08000 & $\$ 80.00$ & $\$ 20,000$ \\
\hline 1 & $0.25 \mathrm{hr} / \mathrm{drum}$ & 250 & $63 A 00$ & $\$ 53.99$ & $\$ 13,498$ \\
\hline 1 & $0.25 \mathrm{hr} / \mathrm{drum}$ & 250 & $63 \mathrm{AO0}$ & $\$ 49.56$ & $\$ 12,390$ \\
\hline 2000 & $20 \$ /$ drum & & & 1.2 & $\$ 48,000$ \\
\hline 1 & $0.1 \mathrm{hr} / \mathrm{drum}$ & 100 & 32800 & $\$ 55.06$ & $\$ 5,506$ \\
\hline
\end{tabular}

Dispose of LLW in LLBG

Fraction of Retrieved Dru

Review/Correct Paperwork

Ship Waste/Place in LLBG

0.5

Gen Svcs

SWITS

NPO

RCT

Teamster

SWITS

WMNW

\begin{abstract}
$0.5 \mathrm{hr} / \mathrm{drum}$
$0.33 \mathrm{hr} / \mathrm{drum}$

$0.25 \mathrm{hr} / \mathrm{drum}$

$0.25 \mathrm{hr} / \mathrm{drum}$

$0.25 \mathrm{hr} / \mathrm{drum}$

$0.1 \mathrm{hr} / \mathrm{drum}$

$0.25 \mathrm{hr} / \mathrm{drum}$
\end{abstract}

$500 \quad 33200$

$330 \quad 32800$

$250 \quad 63 A 00$

$250 \quad 63 A 00$

25063700

$100 \quad 32800$

$250 \quad 08000$
$\$ 55.06$

$\$ 55.06$

$\$ 53.99$

$\$ 49.56$

$\$ 39.98$

$\$ 55.06$

$\$ 80.00$
$\$ 27,530$

$\$ 18,170$

$\$ 13,498$

$\$ 12,390$

$\$ 9,995$

$\$ 5,506$

$\$ 20,000$

$\$ 2,706,505$

Subtotal 7 th Campaign

\section{Excavation}

NPO
RCT
1 st line spvsr
HEO
Heavy Equip
Guzzler
$1 \quad 120 \mathrm{hrs}$
$120 \mathrm{hrs}$
$60 \mathrm{hrs}$
$120 \mathrm{hrs}$
$1000 \$ /$ day
$250 \$ /$ day
$120 \quad 63 A 00$
$120 \quad 63 A 00$
$60 \quad 32 A 00$
$120 \quad 08000$

$\begin{array}{rr}\$ 53.99 & \$ 6,479 \\ \$ 49.56 & \$ 5,947 \\ \$ 84.67 & \$ 5,080 \\ \$ 64.58 & \$ 7,750 \\ 1.2 & \$ 12,000 \\ 1.2 & \$ 25,500\end{array}$

Retrieval Activities

Includes retrieval, inspection, staging, labeling, providing to assay, stage LLW, and stage TRU waste

1 hour per drum

\# of drums in campaign 2000

$\begin{array}{lrr}\text { NPO } & 3 & 1 \mathrm{hr} / \mathrm{drum} \\ \text { RCT } & 2 & 1 \mathrm{hr} / \text { drum } \\ \text { 1st line spvsr } & 0.5 & 1 \mathrm{hr} / \mathrm{drum} \\ \text { Safety } & 0.5 & 1 \mathrm{hr} / \text { drum } \\ \text { Crane Crew } & 20 & 3580 \$ / \text { day } \\ \text { Materials } & 2000 & 20 \$ / \text { drum }\end{array}$

$\begin{array}{ll}6000 & 63 A 00 \\ 4000 & 63 A 00\end{array}$

$1000 \quad 32 \mathrm{A00}$

$1000 \quad 32400$

71600

$\begin{array}{rr}\$ 53.99 & \$ 323,940 \\ \$ 49.56 & \$ 198,240 \\ \$ 84.67 & \$ 84,670 \\ \$ 65.72 & \$ 65,720 \\ 1.2 & \$ 85,920 \\ 1.2 & \$ 48,000\end{array}$

Mobile Assay campaign

Assay system setup/testing

\begin{abstract}
mob/demob fee
\end{abstract}
NPO

PO Contract

PO Conract

2000

$40000 \mathrm{hr}$

$500 \$ /$ drum

$80 \quad 63 A 00$

$\begin{array}{rr}\$ 53.99 & \$ 4,319 \\ 1.2 & \$ 48,000 \\ 1.2 & \$ 1,200,000\end{array}$

Overpacking

Fraction of drums requiring overpacking

NPO

RCT
0.2

2

2

$1 \mathrm{hr} / \mathrm{drum}$
$1 \mathrm{hr} / \mathrm{drum}$

$\begin{array}{ll}800 & 63 A 00 \\ 400 & 63 A 00\end{array}$

$\$ 53.99$
$\$ 49.56$

$\$ 43,192$

$\$ 19,824$ 
Vent unvented drums

Assume venting is done at LLBG

Fraction of drums requiring venting

NPO

RCT

Indust. Hyg

Materials

$\begin{array}{rl}0.1 & \\ 2 & 1 \mathrm{hr} / \mathrm{drum} \\ 1 & 1 \mathrm{hr} / \mathrm{drum} \\ 1 & 1 \mathrm{hr} / \mathrm{drum}\end{array}$

$400 \quad 63 A 00$

$200 \quad 63 A 00$

20031300

$\$ 53.99$

$\$ 49.56$

$\$ 58.81$

$50 \$ / d r u m$

1.2

$\$ 21,596$

$\$ 9,912$

$\$ 11,762$

$\$ 12,000$

Ship TRU Drums to CWC

Fraction of Retrieved Drums which are TRU

Review/Correct Paperwork

Gen Sves

Ship Waste to CWC

SWITS

NPO

RCT

Teamster

WMNW

Receive Waste at CWC

NPO

RCT

Materials

SWITS

0.5

1

$2 \mathrm{hr} / \mathrm{drum}$

$0.33 \mathrm{hr} / \mathrm{drum}$

$2000 \quad 33200$

$\$ 55.06$

$330 \quad 32800$

$\$ 55.06$

$\$ 110,120$

$0.25 \mathrm{hr} / \mathrm{drum}$

$0.25 \mathrm{hr} / \mathrm{drum}$

$250 \quad 63 A 00$

$\$ 53.99$

$250 \quad 63 A 00 \quad \$ 49.56$

$250 \quad 63700 \quad \$ 39.98$

$0.25 \mathrm{hr} / \mathrm{drum}$

$250 \quad 08000$

$\$ 80.00$

$\$ 18,170$

$\$ 13,498$

$\$ 12,390$

$\$ 9,995$

$\$ 20,000$

$250 \quad 63 A 00$

$\$ 53.99$

$0.25 \mathrm{hr} / \mathrm{drum}$

$0.25 \mathrm{hr} / \mathrm{drum}$

$250 \quad 63 A 00$

$\$ 49.56$

$\$ 13,498$

$20 \$ / \mathrm{drum}$

$0.1 \mathrm{hr} / \mathrm{drum}$

$100 \quad 32800$

1.2

$\$ 55.06$

$\$ 12,390$

$\$ 48,000$

$\$ 5,506$

Dispose of LLW in LLBG

Fraction of Retrieved Dru

Review/Correct Paperwork

0.5

Ship Waste/Place in LLBG

Gen Sves

SWITS

$0.5 \mathrm{hr} / \mathrm{drum}$

$500 \quad 33200$

$\$ 55.06$

$\$ 55.06$

$\$ 27,530$

$0.33 \mathrm{hr} / \mathrm{drum}$

$250 \quad 63 A 00$

$\$ 53.99$

RCT

Teamster

SWITS

WMNW

$0.25 \mathrm{hr} / \mathrm{drum}$

$0.25 \mathrm{hr} / \mathrm{drum}$

$0.25 \mathrm{hr} / \mathrm{drum}$

$0.1 \mathrm{hr} / \mathrm{drum}$

$0.25 \mathrm{hr} / \mathrm{drum}$

$250 \quad 63 A 00$

$250 \quad 63700$

$\$ 49.56$

$\$ 39.98$

$100 \quad 32 \mathrm{~B} 00 \quad \$ 55.06$

$\$ 80.00$

$\$ 18,170$

$\$ 13,498$

$\$ 12,390$

$\$ 9,995$

$\$ 5,506$

$\$ 20,000$

Subtotal 8th Campaign

$\$ 2,706,505$

\section{Grand Total Covered Retrieval}

$\$ 11,906,315$

\section{D-18}




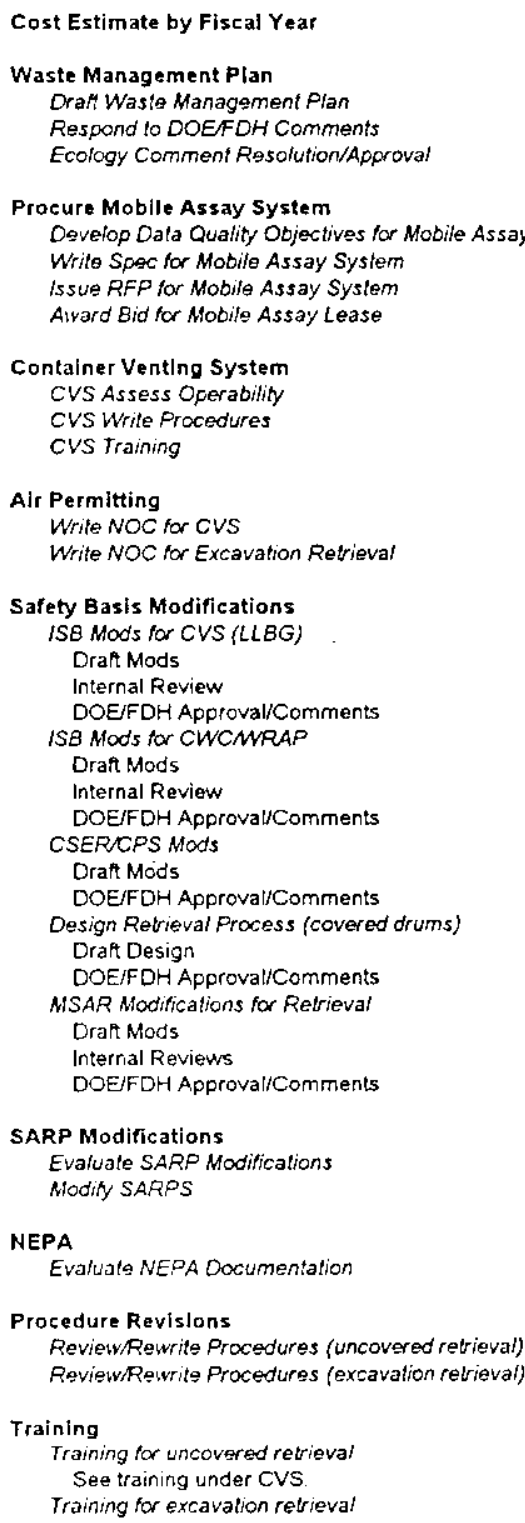

Prestart Activities

Readiness Review Prepare readiness checklistaffadavits Readiness revie!r team

Records Review 1st campalgn

Records Review 2nd campaign

Records Review 3rd campaign

Records Review 4th campaign

Records Revlew 5th campaign

Records Review 6th campaign

Records Review 7th campaign

Records Review 8th campaign

Retrieval 1st campaign

Evaluate 1st campaign

FY99

$\$ 30.991$

$\$ 9.391$

$\$ 12,679$

\section{$\$ 23,666$}

58,799

$\$ 12,178$

57,963

$\$ 36,595$

$\$ 7,745$
$\$ 36,595$

$\$ 36,595$

$\$ 7,313$
$\$ 36,595$

$\$ 39,174$

$\$ 33,966$

5109,785

$\$ 21,938$

$\$ 10,676$

$\$ 30,644$

$\$ 6.917$

$\$ 21,985$

$\$ 21,990$

$\$ 14,185$

$\$ 47,282$
$\$ 246,159 \quad \$ 28,806$

$\$ 13,874$
$\$ 31,932$

$\$ 36,595$

$\$ 33,966$

$\$ 109,786$

$\$ 146,256$

$\$ 54,247$

$\$ 33,097$

$\$ 70,923$

$\$ 94,554$

$\$ 9.4,564$

$\$ 94,564$ 
Retrieval 2nd campalgn

Retrieval 3rd campaign

Retrleval 4th campalgn

Retrieval 5 th campaign

Retrieval 6th campaign

Retrleval 7th campaign

Retrleval 8th campaign

Annual Subtotals
$\$ 497,612$

$\$ 999,58$ :

$\$ 1,456,121$

$\$ 2,330,679$

$\$ 2,706,505$

$\$ 2,706,505$

$\$ 2,706,505$

$\$ 409,921 \quad \$ 1,041,844$ 


\begin{tabular}{|c|c|c|c|c|c|c|c|c|c|c|}
\hline Cost Estimate by Fiscal Year & Project Risk & Risk Factor & FY9s & FYoO & FYot & FYOZ & Fros & Frod & Fros & Fras \\
\hline $\begin{array}{l}\text { Waste Management Plan } \\
\text { Oraf Waste Management Plan } \\
\text { Respond to DOEFPH Comments } \\
\text { Ecology Comment Resolution'Approvat }\end{array}$ & $\begin{array}{l}\text { Low } \\
\text { Medum } \\
\text { Highest }\end{array}$ & $\begin{array}{l}0.05 \\
0.10 \\
0.25\end{array}$ & $\begin{array}{l}\$ 32,541 \\
\$ 10,330\end{array}$ & $\$ 15,849$ & & & & & & \\
\hline 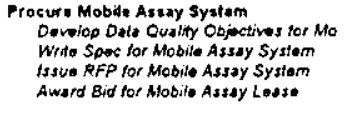 & $\begin{array}{l}\text { Low } \\
\text { Low } \\
\text { Low } \\
\text { Medum }\end{array}$ & $\begin{array}{l}0.05 \\
0.05 \\
0.05 \\
0.10\end{array}$ & $\begin{array}{r}\$ 13,250 \\
\$ 18,933 \\
\$ 2,470 \\
\$ 7,410\end{array}$ & & & & & & & \\
\hline $\begin{array}{l}\text { Container Venting System } \\
\text { CVS Assess Oporabilhy } \\
\text { CVS Write Procodures } \\
\text { CVS Training }\end{array}$ & $\begin{array}{l}\text { Medium } \\
\text { Medium } \\
\text { Medium }\end{array}$ & $\begin{array}{l}0.10 \\
0.10 \\
0.10\end{array}$ & & $\begin{array}{r}\$ 26,033 \\
\$ 5,077 \\
\$ 13,396\end{array}$ & & & . & & & \\
\hline $\begin{array}{l}\text { Air Perminting } \\
\text { Wrte NOC for CVS } \\
\text { Write NOC for Exescalion Rotrienal }\end{array}$ & $\begin{array}{l}\text { Medurm } \\
\text { High }\end{array}$ & $\begin{array}{l}0.10 \\
0.15\end{array}$ & 58,781 & & $\$ 38,722$ & & & & & \\
\hline $\begin{array}{l}\text { Saroty Basis Modifiteatlons } \\
\text { ISA Niods for CVS (LLAG) } \\
\text { Drat Mods }\end{array}$ & Low & 0.05 & & $\$ 38.425$ & & & & & & \\
\hline $\begin{array}{l}\text { Internal Review } \\
\text { OOESFH AOprovavCommints } \\
\text { ISB Mods for CWCWRAP }\end{array}$ & $\begin{array}{l}\text { Medium } \\
\text { Hhghost }\end{array}$ & $\begin{array}{l}0.10 \\
0.25\end{array}$ & & $\begin{array}{r}\$ 8,519 \\
\$ 45,744\end{array}$ & & & & & & \\
\hline $\begin{array}{l}\text { ORAt Mods } \\
\text { interinal Revew } \\
\text { OOEIFDH ADprovavConments } \\
\text { CSERTPS MOds }\end{array}$ & $\begin{array}{l}\text { Low } \\
\text { Mediurn } \\
\text { Highest }\end{array}$ & $\begin{array}{l}0.05 \\
0.10 \\
0.25\end{array}$ & & $\begin{aligned} \$ 38,425 \\
\$ 8.044 \\
\$ 45.744\end{aligned}$ & & & & & & \\
\hline $\begin{array}{l}\text { OCAR Mods } \\
\text { OOE } / \text { FDH ADprovalV Comments }\end{array}$ & $\begin{array}{l}\text { Low } \\
\text { Hoghast }\end{array}$ & $\begin{array}{l}0.05 \\
0.25\end{array}$ & & & $\begin{array}{l}\$ 38,425 \\
\$ 42,458\end{array}$ & & & & & \\
\hline 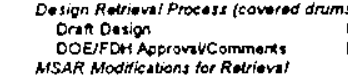 & $\begin{array}{l}\text { Is) } \\
\text { Cow } \\
\text { Highest }\end{array}$ & $\begin{array}{l}0.05 \\
0.25\end{array}$ & & $\begin{array}{l}\$ 41,132 \\
\$+2,450\end{array}$ & & & & & & \\
\hline $\begin{array}{l}\text { Orat Mods } \\
\text { Imemal Revimm } \\
\text { DOEJFDH ApprovaVComments }\end{array}$ & $\begin{array}{l}\text { Low } \\
\text { Medhum } \\
\text { Kighost }\end{array}$ & $\begin{array}{l}0.05 \\
0.10 \\
0.25\end{array}$ & & $\$ \$ 15.275$ & $\$ 137,232$ & & & & & \\
\hline $\begin{array}{l}\text { SARP Modificatlons } \\
\text { Evaluate SARRP Alodfications } \\
\text { Mlodty SARPS }\end{array}$ & $\begin{array}{l}\text { Low } \\
\text { Medium }\end{array}$ & $\begin{array}{l}0.05 \\
0.10\end{array}$ & $\$ 11,210$ & $\$ 33,708$ & & & & & & \\
\hline $\begin{array}{l}\text { NEPA } \\
\text { Evatusto NEPA Documontalion }\end{array}$ & Low & 0.05 & $\$ 7,293$ & & & & & & & \\
\hline $\begin{array}{l}\text { Procedure Revisions } \\
\text { Revisw/Rewrte Procodures funcoverod } \\
\text { Reviow/Rewrto Procodures (axcaration }\end{array}$ & $\begin{array}{l}\text { Low } \\
\text { Medum }\end{array}$ & $\begin{array}{l}0.05 \\
0.10\end{array}$ & $\$ 23,084$ & & $.390,733$ & & & & & \\
\hline $\begin{array}{l}\text { Training } \\
\text { Traning for uncovered retrioval } \\
\text { See training under CVS. } \\
\text { Training for exteration rotioval }\end{array}$ & Mesium & 0.10 & & & $\$ 50.780$ & & & & & \\
\hline Prestart Activities & Low & 0.05 & $\$ 23.090$ & & · & & & & & \\
\hline 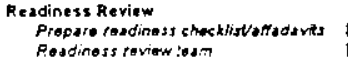 & $\begin{array}{l}\text { Hghest } \\
\text { Highest }\end{array}$ & $\begin{array}{l}0.25 \\
0.25\end{array}$ & & & $\begin{array}{l}\$ 182,820 \\
\$ 87,809\end{array}$ & & & & & \\
\hline Records Review 1st campaign & Low & 0.05 & 514,894 & & & & & & & \\
\hline Records Roview 2nd campaign & Low & 0.05 & & $\$ 49,848$ & & & & & & \\
\hline Recards Review Jrd campalgn & Low & 0.05 & & & 534,752 & & & & & \\
\hline Records Review sth campaign & Low & 0.05 & & & - & $\$ 74,469$ & & & & \\
\hline Records Review Sth campaign & Low & 0.05 & & & & & $\$ 99,292$ & & & \\
\hline Records Review th eampaign & Low & 0.05 & & & & & & 599.282 & & \\
\hline Records Review 7th campaign & Low & 0.05 & & & & & & & $\$ 99.292$ & \\
\hline Records seview sth campaign & Low & 0.05 & & & & & & & & $\$ 49,646$ \\
\hline Retrieval 1st campagn & Mestum & 0.10 & $\$ 270,775$ & $\$ 31,887$ & & & & & & \\
\hline Evaluate Ist campaign & Low & 0.05 & & $\$ 14,588$ & & & & - & & \\
\hline Retrieva! 2nd campangn & Medium & 0.10 & & $\$ 547,373$ & & & & & & \\
\hline Retrieval 3rd campaign & Medum & 0.10 & & & $\$ 1,099,539$ & & & & & \\
\hline Retrieval 4th campaign & High & 0.15 & & & & $\$ 1,674,540$ & & & & \\
\hline Retrieral 51h campaign & High & 0.15 & & & & & $\$ 2,880.290$ & & & \\
\hline Retrieval sth campagn & High & 0.15 & & & & & & $\$ 3.112,481$ & & \\
\hline Retrieval 7th campaign & High & 0.15 & & & & & & & $\$ 3.1 \pm 2.491$ & \\
\hline Retrieval sth campagn & High & 0.15 & & & & & & & & $53.112,481$ \\
\hline Annual Subtotals & & & $\$ 443,931$ & $\$ 1,149,8]$ & $81,797,270$ & $\$ 1,749,009$ & $52,779,573$ & $53,211,773$ & $53,211,773$ & $5], 162,127$ \\
\hline Escalation & & & 1.000 & 1.021 & 1.043 & 1.066 & 1.090 & 1.114 & 1.128 & 1.863 \\
\hline Annual Totals & & & $5.433,934$ & $51,173,985$ & $39,124,003$ & $51,865,174$ & $53,029,398$ & $\$ 3,577,458$ & $53,658,160$ & $\$ 3,676,137$ \\
\hline Number of Drums Retrevet & & & 200 & 400 & 700 & 1.000 & 1.700 & $2.0 \mathrm{co}$ & 2.000 & 2.000 \\
\hline Number of Orums Acfes to CWC Invertisy & & & 100 & 200 & 350 & 500 & 850 & $1, \mathrm{CcO}$ & 1,000 & $\$ .000$ \\
\hline Cost per Drum & & & $\$ 2.21965$ & $\$ 2.93496$ & $\$ 2,408.86$ & $\$ 1,88517$ & $\$ 1.782 .00$ & $\$ 1,76873$ & $\$ 1.828 \mathrm{CB}$ & $\$ 1,839.42$ \\
\hline
\end{tabular}


HNF-4781, Revision 1

\section{Appendix E}

\section{Schedule for Phase I Retrieval}




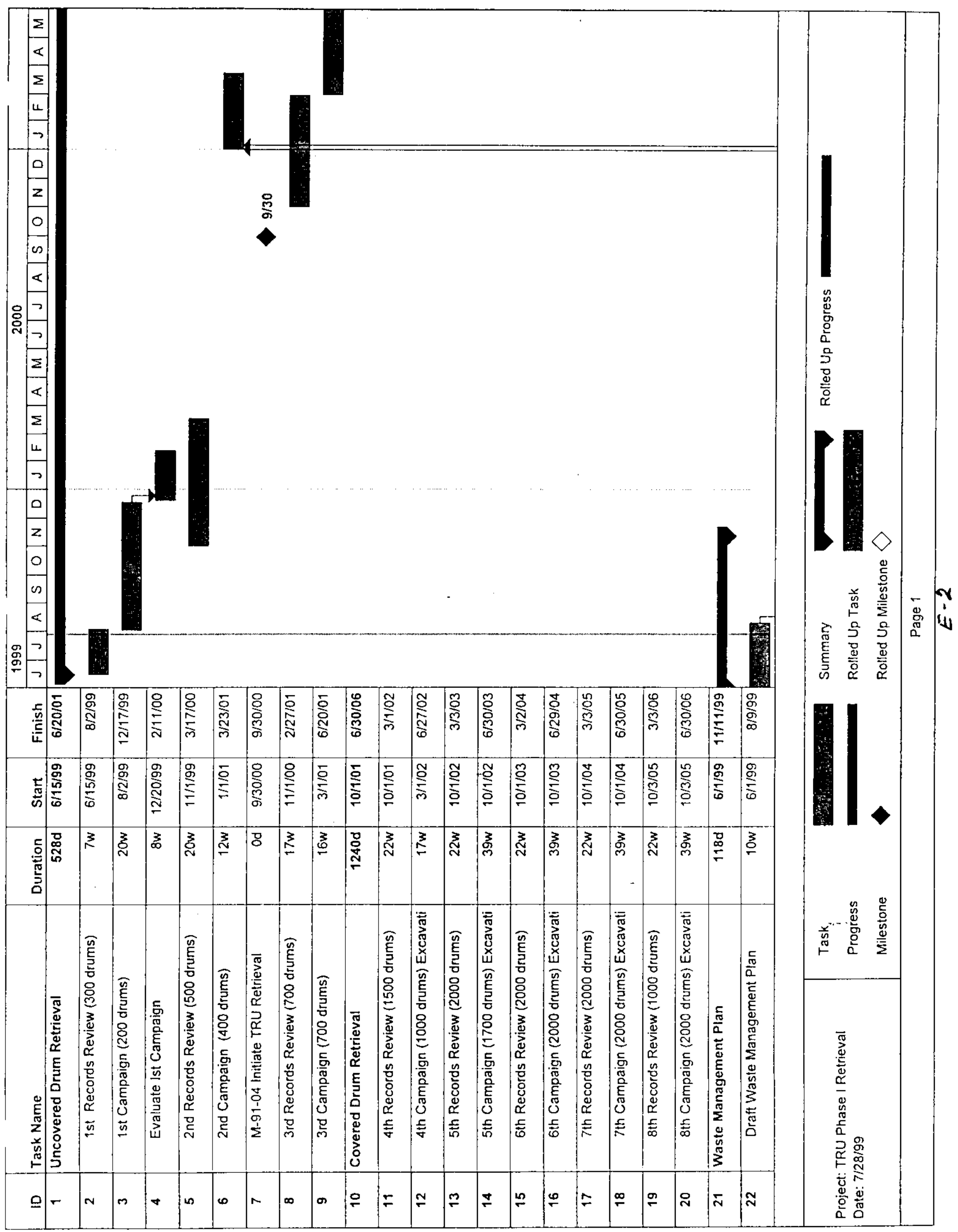




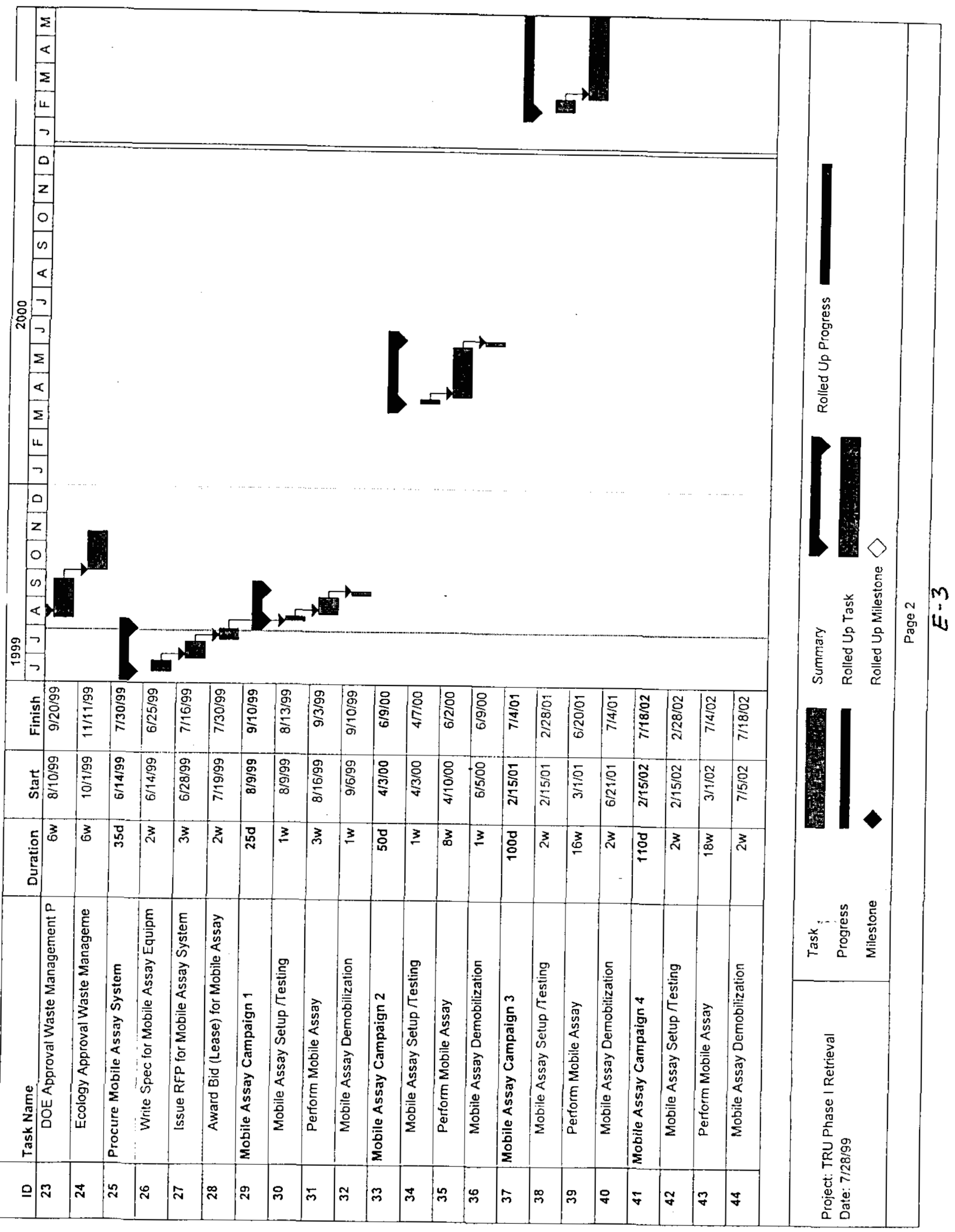




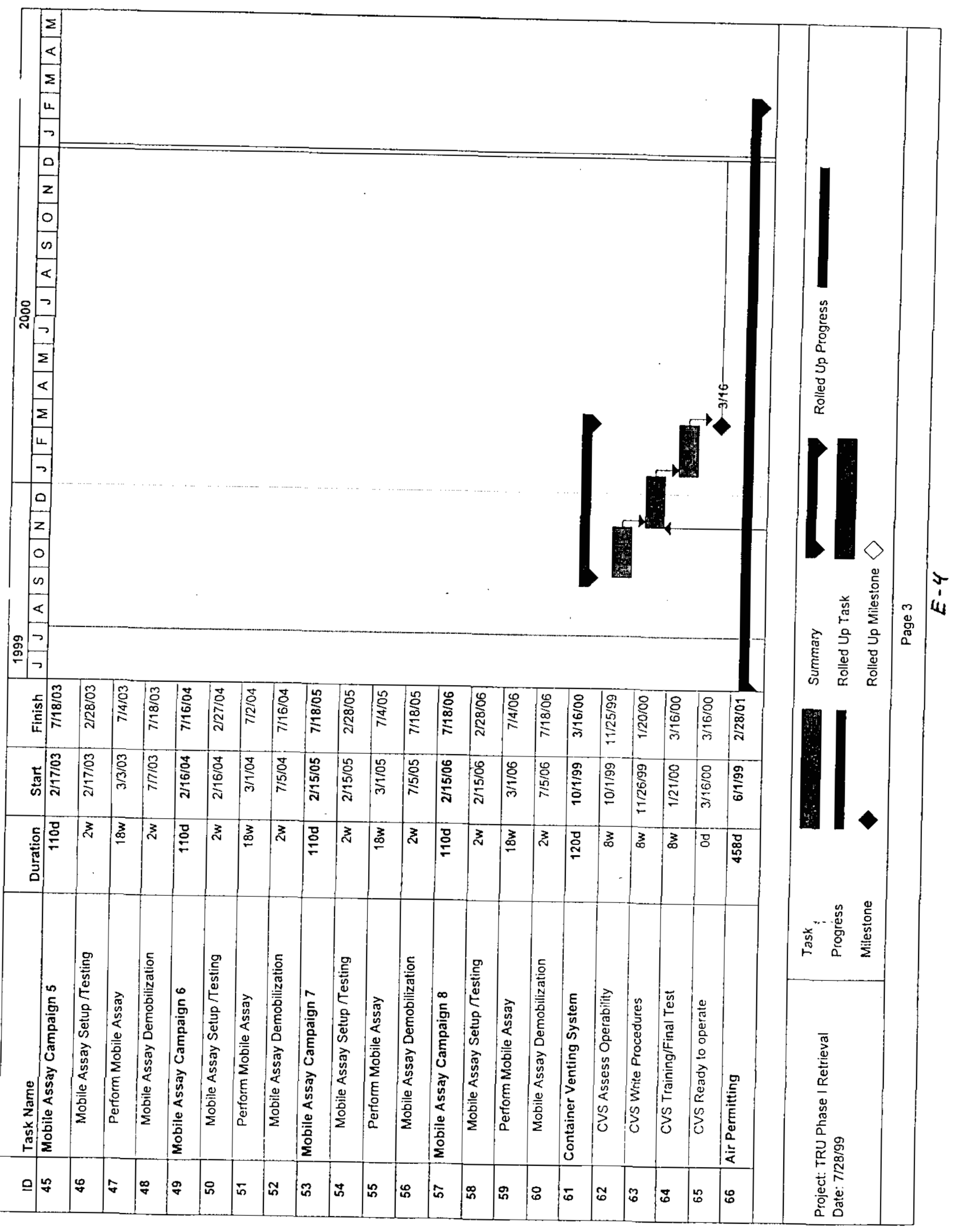




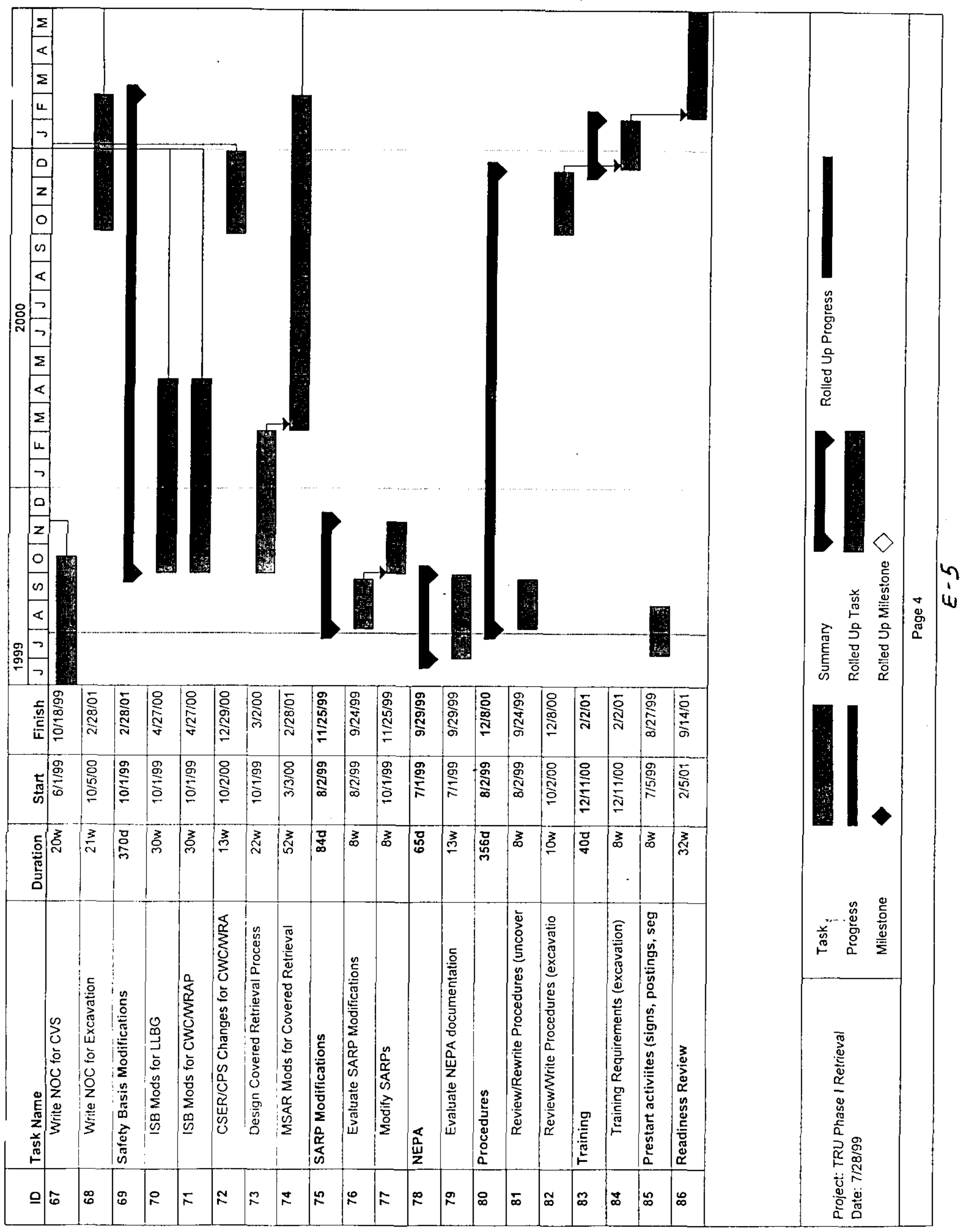




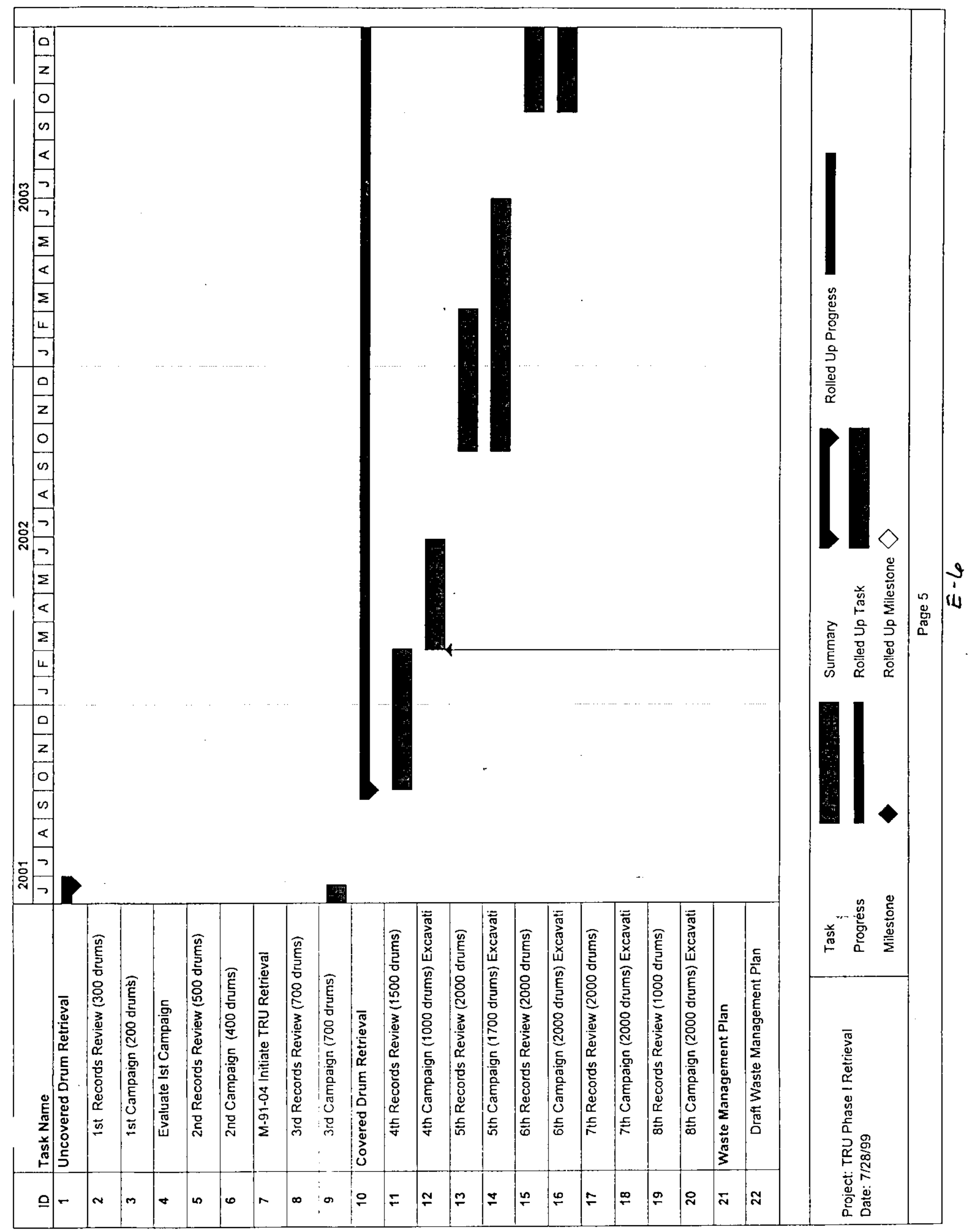




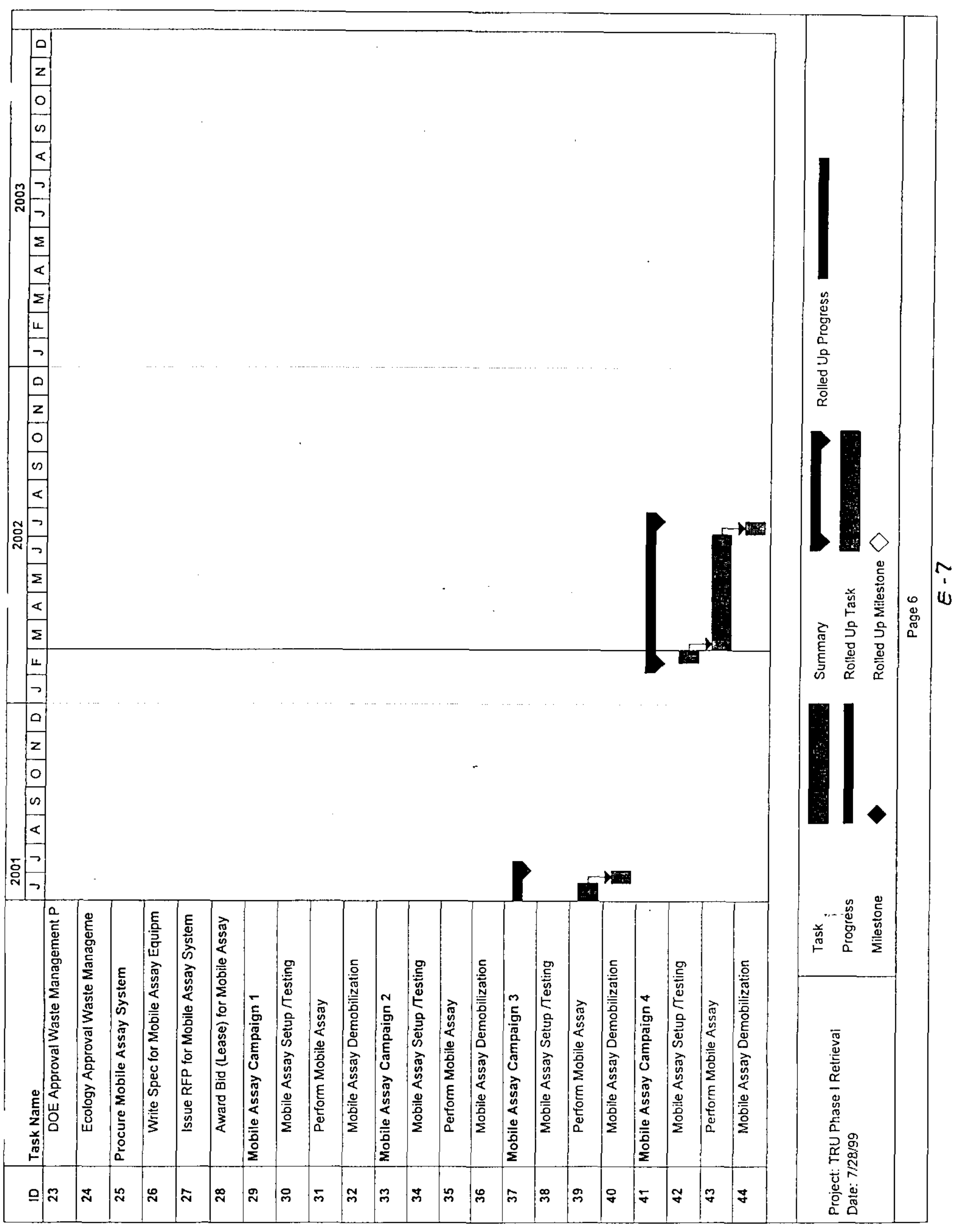




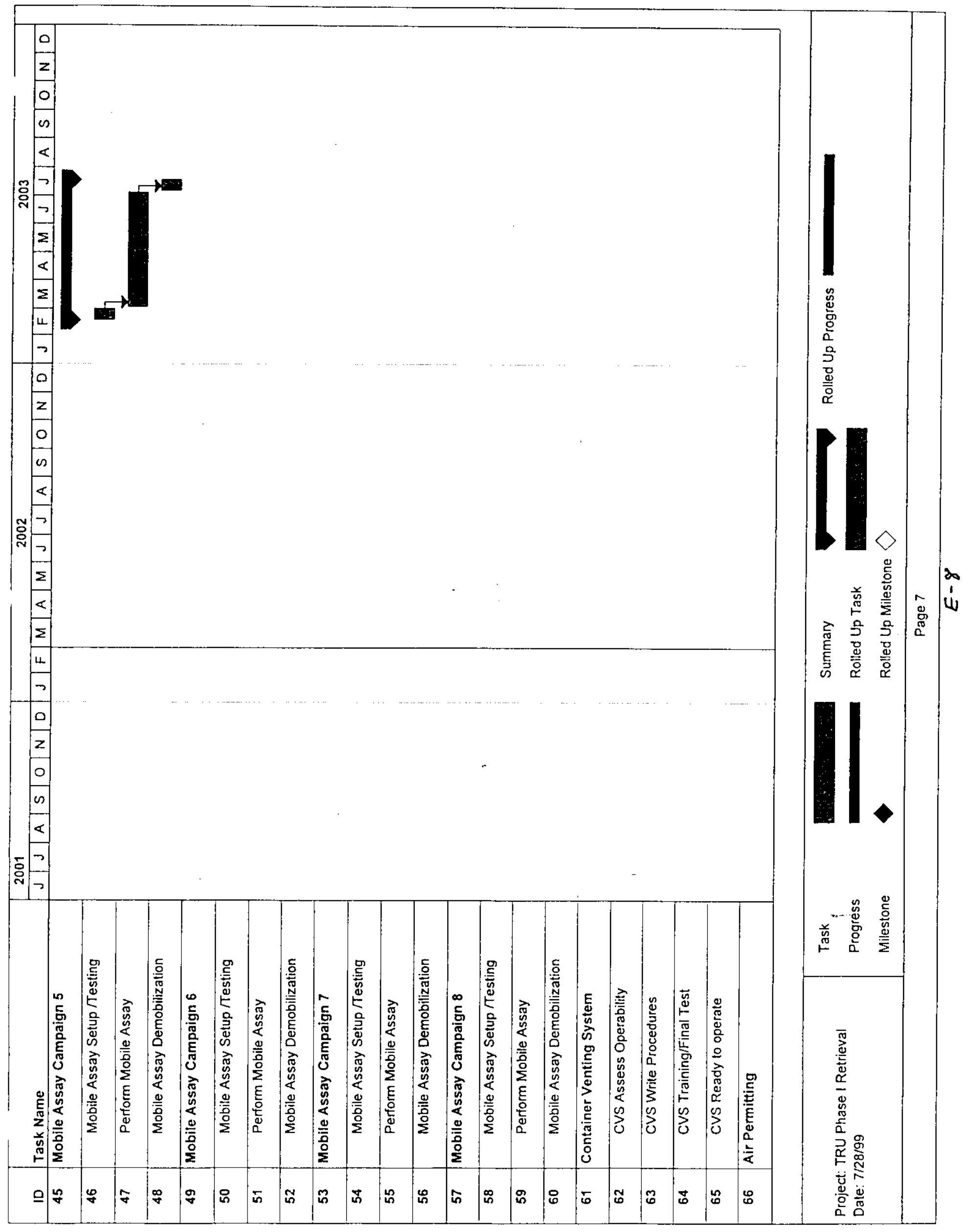




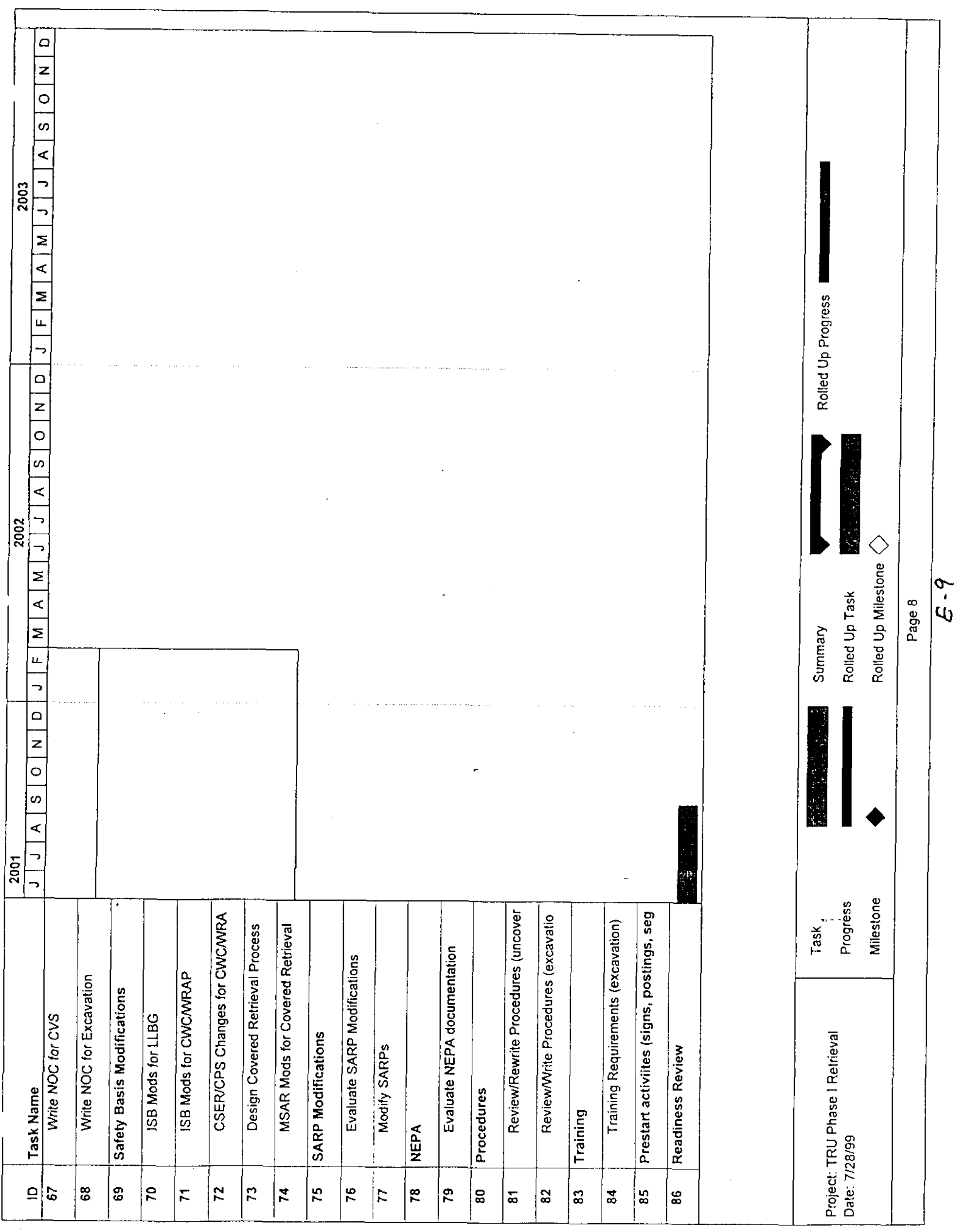




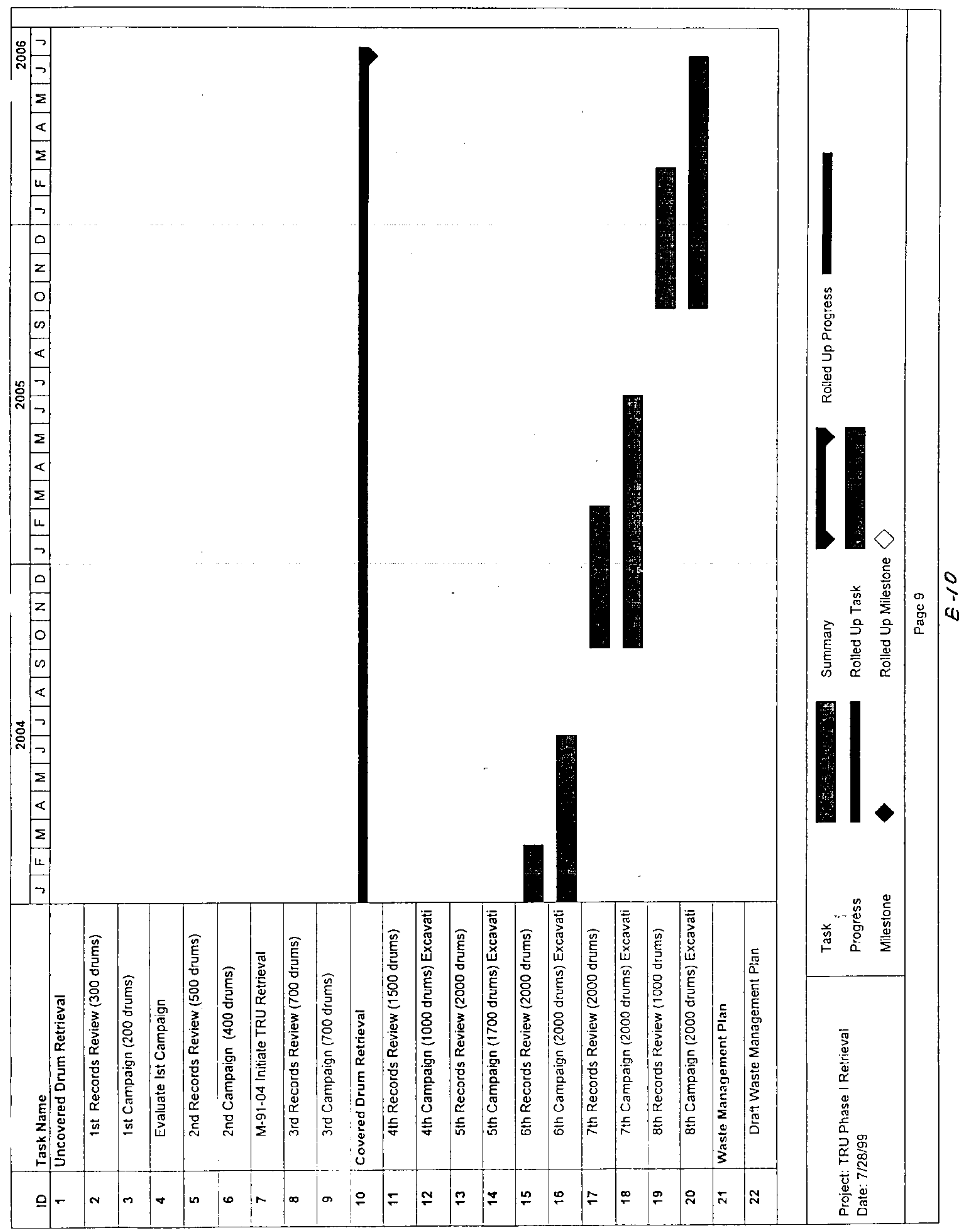




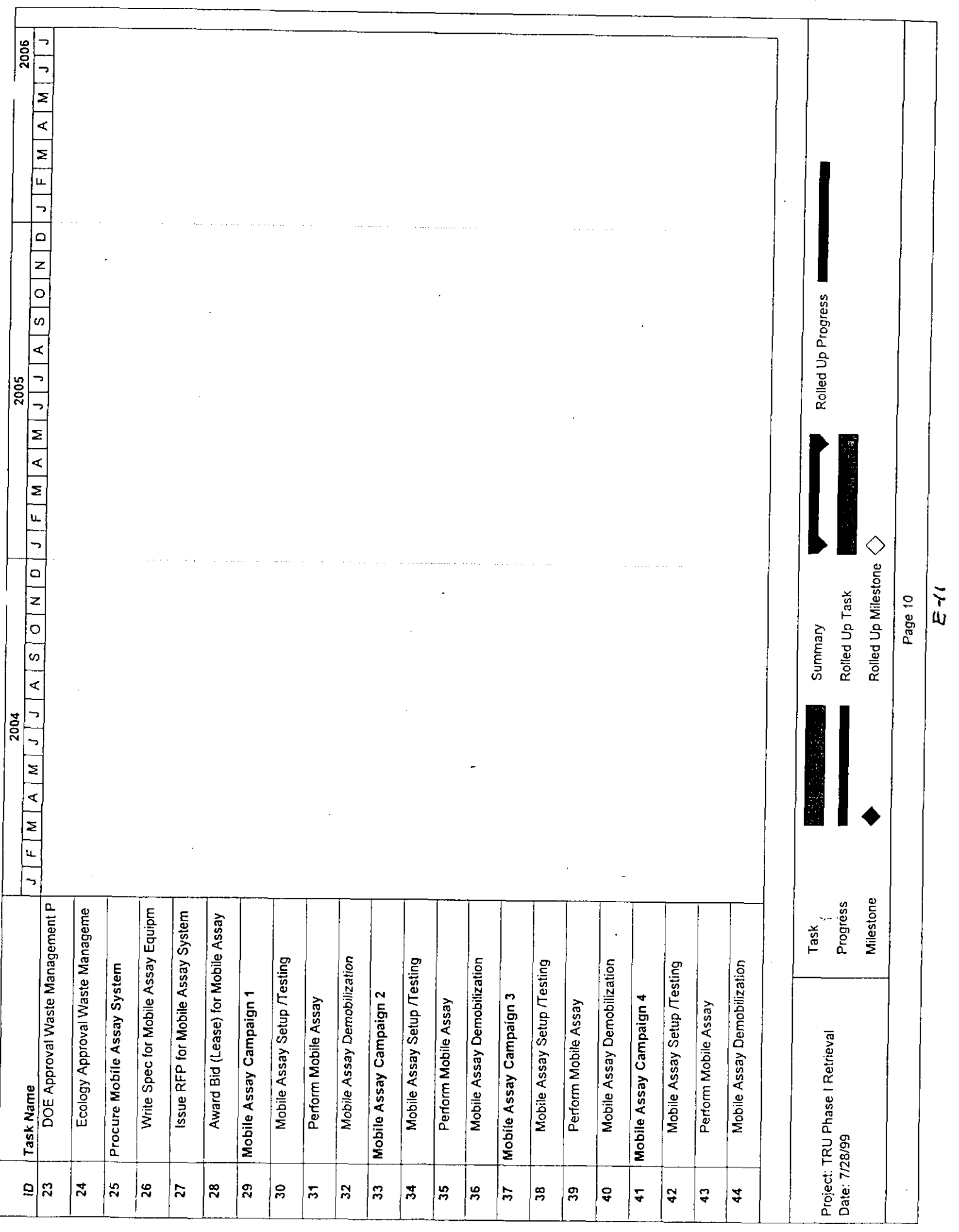




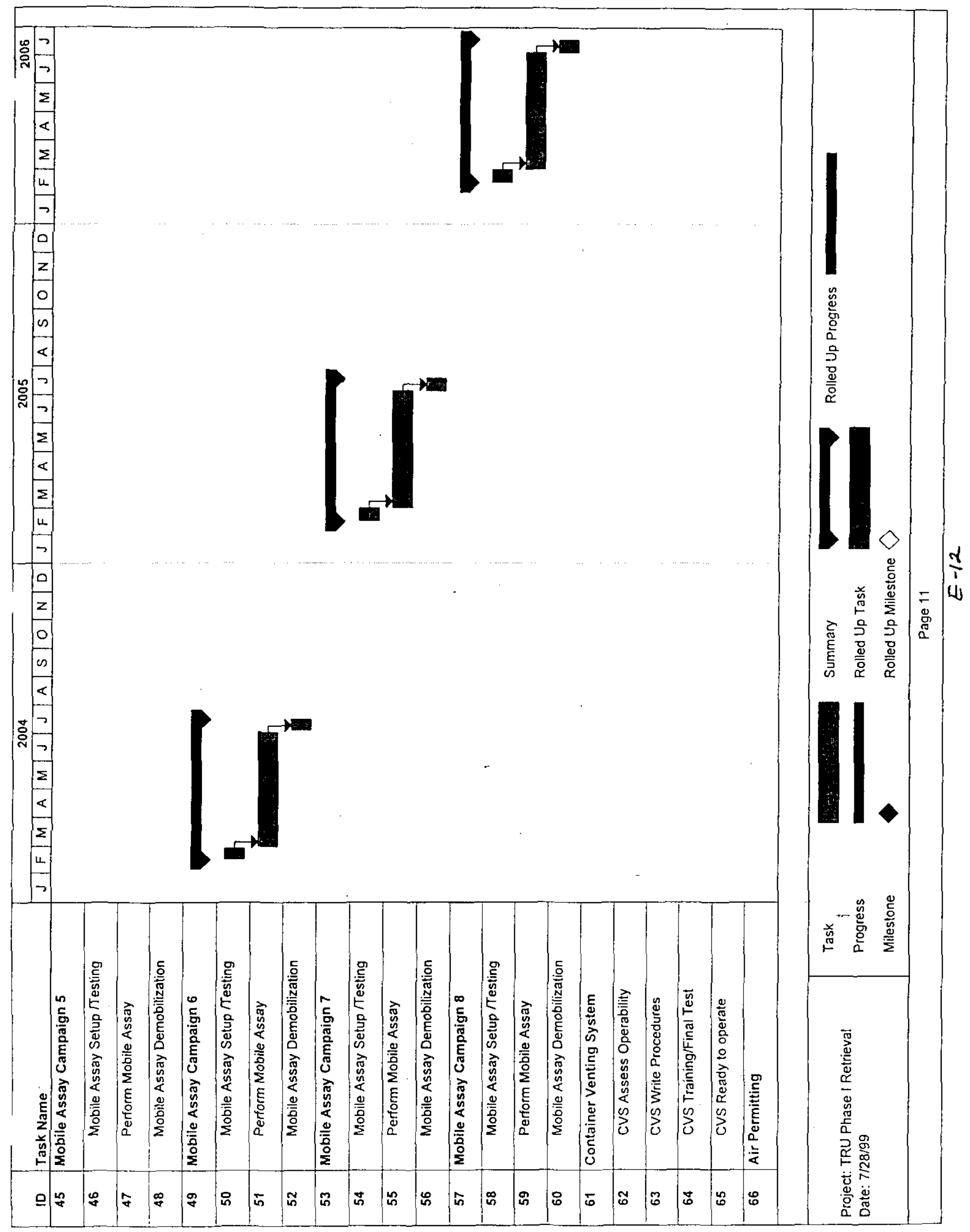




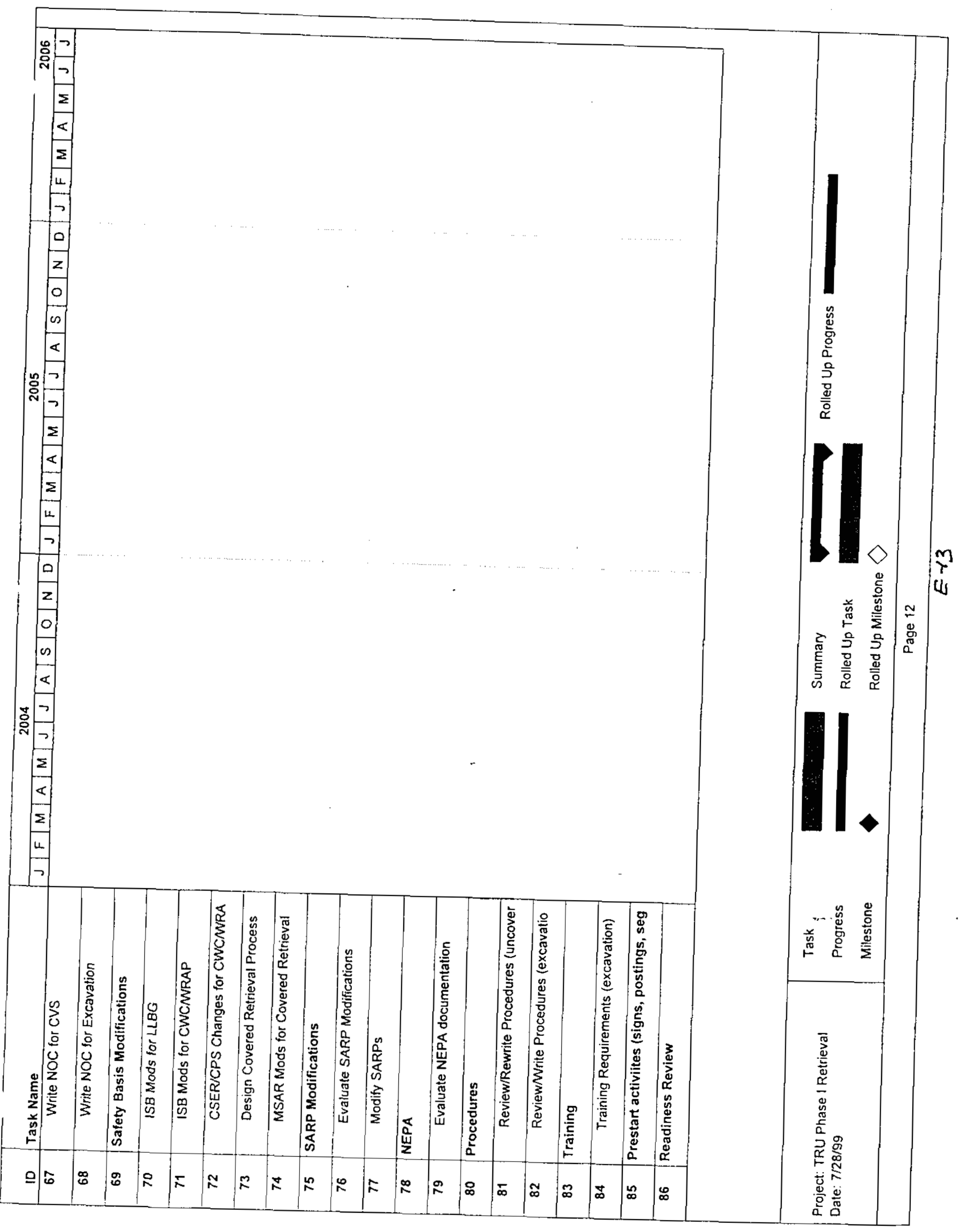

